Prepared in cooperation with the Department of Homeland Security Federal Emergency Management Agency

\title{
Magnitude of Flood Flows for Selected Annual Exceedance Probabilities in Rhode Island Through 2010
}

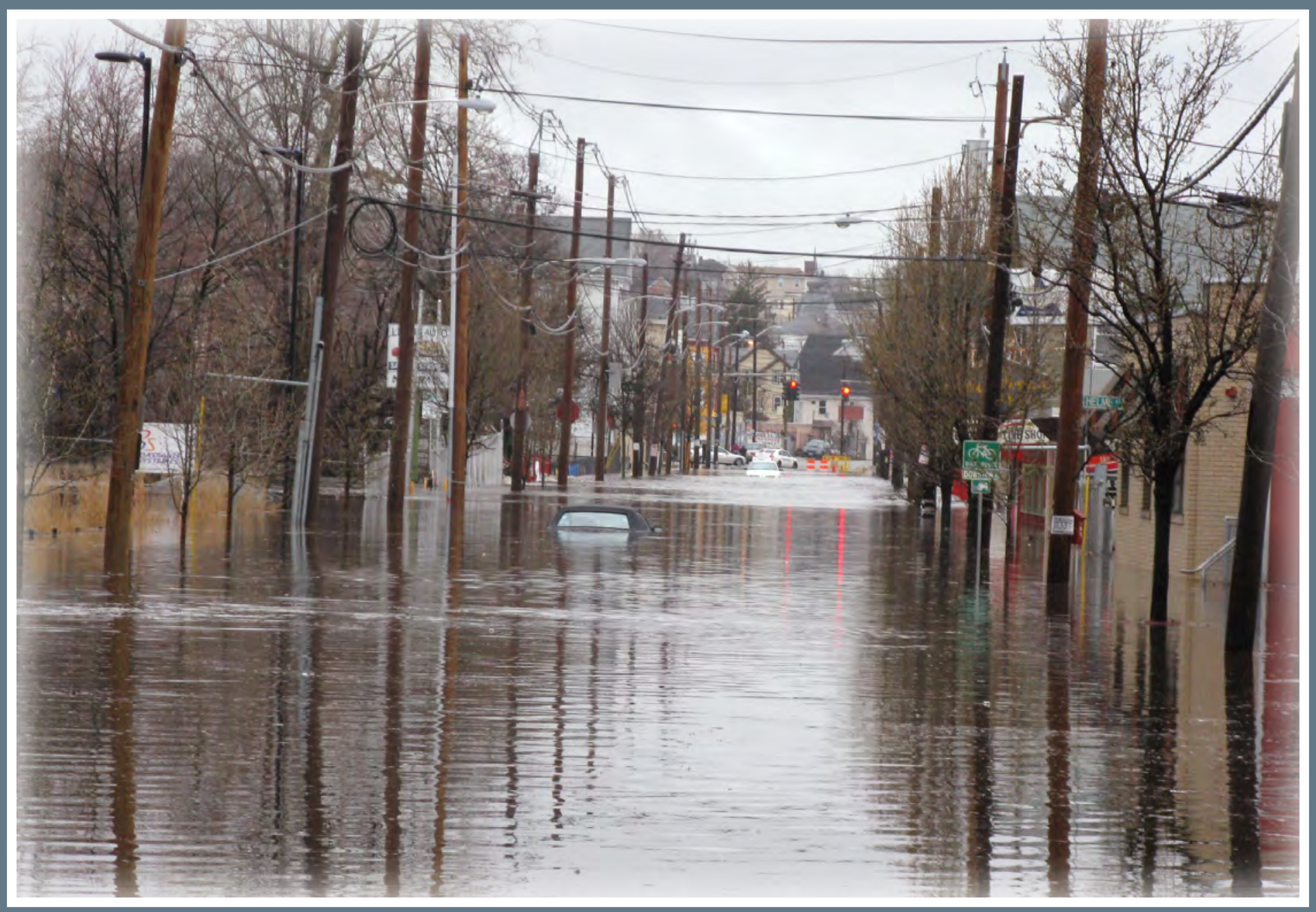

Scientific Investigations Report 2012-5109

Version 1.2, March 2013

U.S. Department of the Interior

U.S. Geological Survey 
Front cover. March-April 2010 flooding along the Woonasquatucket River at Valley Street in Providence, Rhode Island, looking northward toward Atwells Avenue (traffic light) from Helme Street.

Back cover. Historical marker found along Simmons Brook at Simmonsville east of Providence, Rhode Island. 


\section{Magnitude of Flood Flows for Selected Annual Exceedance Probabilities in Rhode Island Through 2010}

By Phillip J. Zarriello, Elizabeth A. Ahearn, and Sara B. Levin

Prepared in cooperation with the Department of Homeland Security

Federal Emergency Management Agency

Scientific Investigations Report 2012-5109

Version 1.2, March 2013 


\section{U.S. Department of the Interior \\ KEN SALAZAR, Secretary \\ U.S. Geological Survey \\ Marcia K. McNutt, Director}

\section{U.S. Geological Survey, Reston, Virginia: 2012}

Revised version 1.2, March 2013, supersedes online version 1.1, released October 2012

For more information on the USGS - the Federal source for science about the Earth, its natural and living resources, natural hazards, and the environment, visit http://www.usgs.gov or call 1-888-ASK-USGS.

For an overview of USGS information products, including maps, imagery, and publications, visit http://www.usgs.gov/pubprod

To order this and other USGS information products, visit http://store.usgs.gov

Any use of trade, product, or firm names is for descriptive purposes only and does not imply endorsement by the U.S. Government.

Although this report is in the public domain, permission must be secured from the individual copyright owners to reproduce any copyrighted materials contained within this report.

Suggested citation:

Zarriello, P.J., Ahearn, E.A., and Levin, S.B., 2012, Magnitude of flood flows for selected annual exceedance probabilities in Rhode Island through 2010 (ver. 1.2, revised March 2013): U.S. Geological Survey Scientific Investigations Report 2012-5109, 81 p. (Also available at http://pubs.usgs.gov/sir/2012/5109.) 


\section{Contents}

Abstract

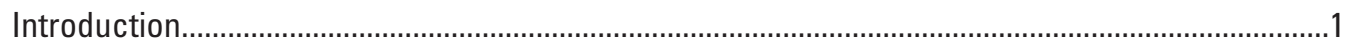

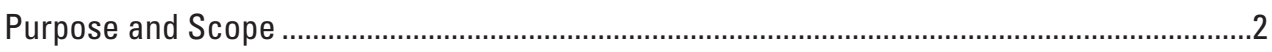

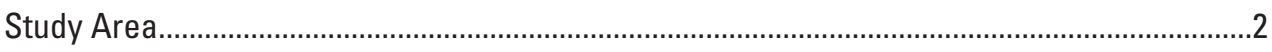

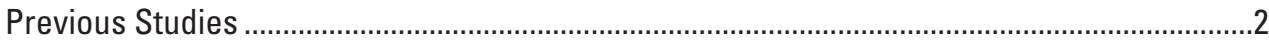

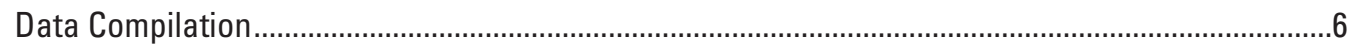

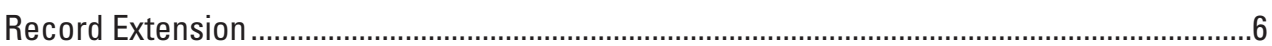

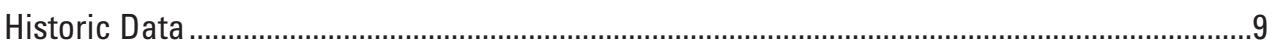

Magnitude of Flood Flows at Streamgages...............................................................................

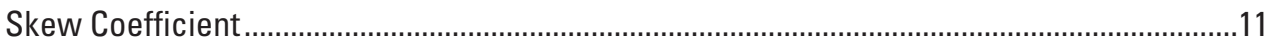

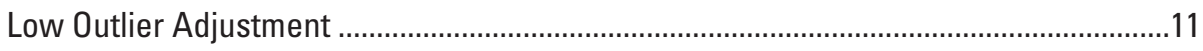

High Outlier Adjustment...................................................................................................

Generalized Regional Skew ..................................................................................13

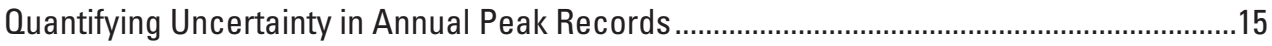

Annual Exceedance Probability Flood Estimates ................................................................18

Uncertainty of Estimates ...................................................................................................18

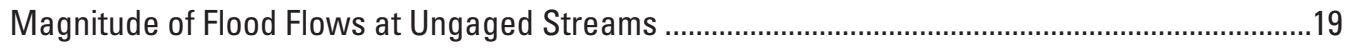

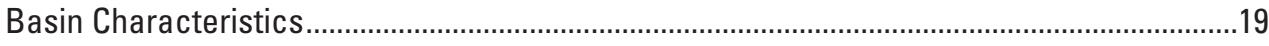

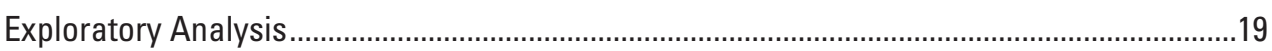

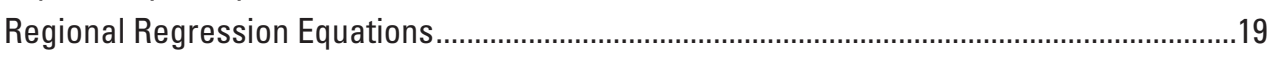

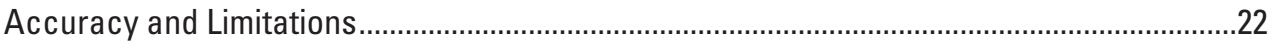

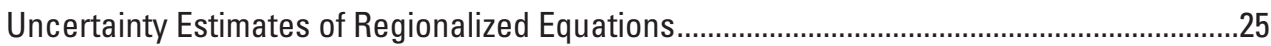

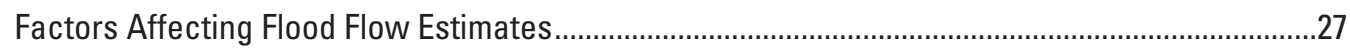

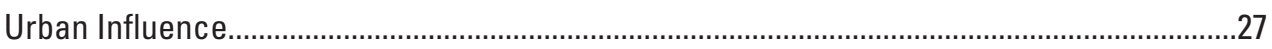

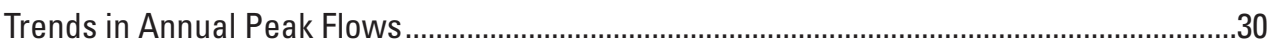

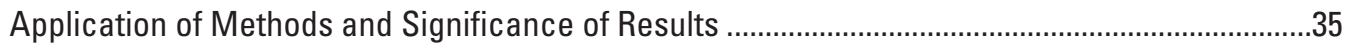

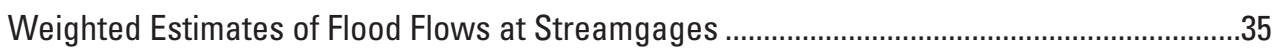

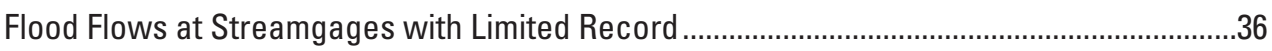

Flood Flows at an Ungaged Site on a Gaged Stream ................................................................

Comparison with a Previous Rhode Island Flood Study .......................................................40

Annual Exceedance Probability of the 2010 Flood in Rhode Island .........................................41

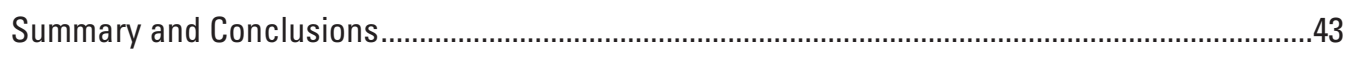

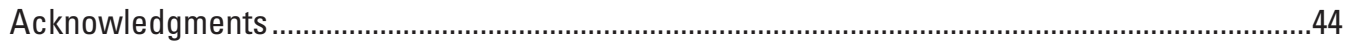

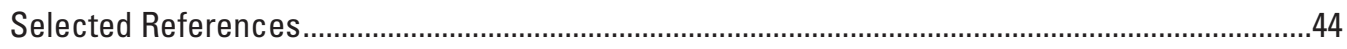

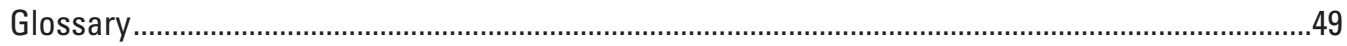

Tables 7, 13, and 15 ......................................................................................................

Appendix 1. Basin Characteristics Considered for Use in the Regional Regression Analysis ...78

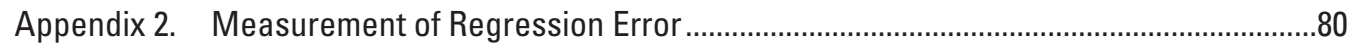

Appendix 3. Link to Spreadsheet RI_Flood-Flow-Equations.xls .................................................81 


\section{Figures}

1. Map showing general area and selected streamgages used in the Rhode Island flood frequency study

2. Map showing land cover in the study area in Rhode Island, Connecticut, and Massachusetts from the 2006 National Land Cover Database.

3. Map showing hurricane and hurricane related storm tracks from 1851 through 2008 in and near Rhode Island.

4. Map showing streamgage skews used to develop the regional skew at selected streamgages in Rhode Island, eastern Connecticut, and south-central and eastern Massachusetts

5. Graph showing upper stage-discharge rating and range of uncertainty of higher annual peak flows used in flood frequency analysis at Mount Hope River near Warrenville, CT (01121000)

6. Graphs showing uncertainty of $A$, annual peak and historic flows used to compute $B$, flood frequency curve at Mount Hope River near Warrenville, CT (01121000)

7. Boxplots showing selected streamgage basin characteristics in Rhode Island, Connecticut, and Massachusetts used in flood frequency analysis

8. Boxplot showing residuals of generalized least squares (GLS) regional regression of floods for 20- to 0.2-percent annual exceedance probabilities at 41 selected streamgages in Rhode Island, Connecticut, and Massachusetts.

9. Map showing residuals of generalized least squares (GLS) regional regression and at-site 1-percent annual exceedance probability flood flows at 41 selected streamgages in Rhode Island, Connecticut, and Massachusetts.

10. Graphs showing flood magnitudes for selected annual exceedance probabilities determined from at-site analyses and from regional flood flow equations at $A$, 41 streamgages in Rhode Island, Connecticut, and Massachusetts, and $B, 18$ streamgages in Rhode Island

11. Graph showing regional regression estimates of the flood flows and confidence intervals for a hypothetical basin.

12. Graphs showing relation of the magnitude of the 20-percent annual exceedance probability flood determined by regionalized equation to impervious area for $A$, all basins and $B$, basins grouped by ranges of the basin underlain by sand and gravel.....28

13. Graph showing ratio of flood magnitudes for select annual exceedance probabilities normalized by drainage area between streamgages with different extents of basin urbanization

14. Boxplot showing ratio of urban to rural peak discharges for 20- and 1-percent annual exceedance probability flood in five states with separate flood flow equations

15. Graphs showing trends in $A$, annual peak flows and detrended annual peaks, $B$, annual peak flows by quartile group, and $C$, decadal count of annual peak flows by quartile group for Branch River at Forestdale, RI (01111500).

16. Graph showing average number of annual peak flows by decade by quartile range among 15 streamgages with statistically significant trends above about the 90-percent confidence level.

17. Boxplot showing projected influence of trends in annual peak flows at 15 longterm streamgages by the $A$, flood magnification factor and $B$, recurrence reduction factor.

18. Boxplot showing range of differences between flood flows calculated from at-site analysis of annual peak flows and weighted independent estimate for selected annual exceedance probabilities. 
19. Boxplot showing differences from at-site analyses and regional regression equations in this study and regression equations from previous study by Johnson and Laraway (1977) for 18 streamgages in Rhode Island (table 7) for 10-, 1-, and 0.2-percent annual exceedance probability floods.

\section{Tables}

1. Streamgages compiled from the U.S. Geological Survey National Water Information System (NWIS) peak-flow database and pertinent characteristics used in regional flood flow analysis for Rhode Island

2. Streamgages used in the flood frequency analysis with extended record made with the maintenance of variance extension (MOVE).

3. Streamgages with historic records used in the study ..................................................10

4. Outliers detected in peak-flow database for streamgages used in the floodfrequency analysis

5. Summary of generalized skew values determined for Rhode Island and nearby surrounding areas . .14

6. Annual exceedance probability, flood quantiles, and confidence limits for Mount Hope River near Warrenville, CT (01121000).

7. Estimated magnitude of flood flows and confidence limits for selected annual exceedance probabilities at selected streamgages in Rhode Island, Connecticut, and Massachusetts for the period of record through 2010

8. Ranges of the basin characteristic values used to develop regional flood flow regression equations

9. Pseudo-coefficient of determination (pseudo- $R^{2}$ ), average variance of prediction, and standard error of prediction for the regional flood flow regression equations........25

10. Model error variance and covariance values needed to determine the uncertainty of the regional regression equations

11. Characteristics of three basins used to compare effects of urbanization

12. Trends in annual peak flows at streamgages with 70 or more years of unregulated systematic recorded identified by the Kendall trend test

13. Magnitude and variance of 20-, 10-, 4-, 2-, 1-, 0.5-, and 0.2-percent annual exceedance probability floods determined from at-site analyses, regional regression equations, and weighted independent estimates.

14. Streamgages with short-term records in Rhode Island that were not used in the regional flood frequency analysis.

15. Estimated magnitude of flood flows and confidence limits for annual exceedance probabilities at short-term streamgages in Rhode Island.

16. Regional exponent for drainage area adjustment of a flood flows at an ungaged site on gaged stream determined from the regional regression of drainage area....

17. March-April 2010 flood peak and annual exceedance probability at active streamgages in Rhode Island. 


\section{Conversion Factors, Datum, and Abbreviations}

Inch/Pound to SI

\begin{tabular}{|c|c|c|}
\hline Multiply & By & To obtain \\
\hline \multicolumn{3}{|c|}{ Length } \\
\hline foot $(\mathrm{ft})$ & 0.3048 & meter $(\mathrm{m})$ \\
\hline mile (mi) & 1.609 & kilometer (km) \\
\hline \multicolumn{3}{|c|}{ Area } \\
\hline acre & 0.4047 & hectare (ha) \\
\hline square mile $\left(\mathrm{mi}^{2}\right)$ & 259.0 & hectare (ha) \\
\hline \multicolumn{3}{|c|}{ Volume } \\
\hline cubic foot $\left(\mathrm{ft}^{3}\right)$ & 0.02832 & cubic meter $\left(\mathrm{m}^{3}\right)$ \\
\hline \multicolumn{3}{|c|}{ Flow rate } \\
\hline cubic foot per second $\left(\mathrm{ft}^{3} / \mathrm{s}\right)$ & 0.02832 & cubic meter per second $\left(\mathrm{m}^{3} / \mathrm{s}\right)$ \\
\hline
\end{tabular}

Temperature in degrees Fahrenheit $\left({ }^{\circ} \mathrm{F}\right)$ may be converted to degrees Celsius $\left({ }^{\circ} \mathrm{C}\right)$ as follows:

$$
{ }^{\circ} \mathrm{C}=\left({ }^{\circ} \mathrm{F}-32\right) / 1.8
$$

Vertical coordinate information is referenced to the North American Vertical Datum of 1988 (NAVD 88).

Horizontal coordinate information is referenced to the North American Datum of 1983 (NAD 83).

Elevation, as used in this report, refers to distance above the vertical datum.

\section{Abbreviations}

$\begin{array}{ll}\text { AEP } & \text { annual exceedance probability } \\ \text { AVP } & \text { average variance of prediction } \\ \text { BDF } & \text { basin development factor } \\ \text { B17B } & \text { Bulletin 17B } \\ \text { DA } & \text { drainage area } \\ \text { EMA } & \text { expected moments algorithm } \\ \text { FEMA } & \text { Federal Emergency Management Agency } \\ \text { GLS } & \text { generalized least square } \\ \text { IACWD } & \text { Interagency Committee on Water Data } \\ \text { IMPERV } & \text { impervious area } \\ \text { LPIII } & \text { log-Pearson type III } \\ \text { MGB } & \text { multiple Grubbs-Beck test } \\ \text { MOVE } & \text { maintenance of variance extension } \\ \text { NFF } & \text { National Flood Frequency }\end{array}$




$\begin{array}{ll}\text { NHD } & \text { National Hydrography Dataset } \\ \text { NOAA } & \text { National Oceanic and Atmospheric Administration } \\ \text { NWIS } & \text { National Water Information System } \\ \text { OLS } & \text { ordinary least squares } \\ \text { PILP } & \text { potentially influential low peaks } \\ \text { RMSE } & \text { root mean square error } \\ \text { StorNHD } & \text { basin storage } \\ \text { STRDEN } & \text { stream density } \\ \text { USACE } & \text { U.S. Army Corps of Engineers } \\ \text { USGS } & \text { U.S. Geological Survey } \\ \text { VIF } & \text { variance inflation factor } \\ \text { WIE } & \text { Weighted Independent Estimator } \\ \text { WLS } & \text { weighted least squares }\end{array}$


THIS PAGE INTENTIONALLY LEFT BLANK 


\title{
Magnitude of Flood Flows for Selected Annual Exceedance Probabilities in Rhode Island Through 2010
}

\author{
By Phillip J. Zarriello, Elizabeth A. Ahearn, and Sara B. Levin
}

\section{Abstract}

Heavy persistent rains from late February through March 2010 caused severe widespread flooding in Rhode Island that set or nearly set record flows and water levels at many long-term streamgages in the State. In response, the U.S. Geological Survey, in partnership with the Federal Emergency Management Agency, conducted a study to update estimates of flood magnitudes at streamgages and regional equations for estimating flood flows at ungaged locations. This report provides information needed for flood plain management, transportation infrastructure design, flood insurance studies, and other purposes that can help minimize future flood damages and risks.

The magnitudes of floods were determined from the annual peak flows at 43 streamgages in Rhode Island (20 sites), Connecticut (14 sites), and Massachusetts (9 sites) using the standard Bulletin 17B log-Pearson type III method and a modification of this method called the expected moments algorithm (EMA) for 20-, 10-, 4-, 2-, 1-, $0.5-$, and 0.2-percent annual exceedance probability (AEP) floods. Annual-peak flows were analyzed for the period of record through the 2010 water year; however, records were extended at 23 streamgages using the maintenance of variance extension (MOVE) procedure to best represent the longest period possible for determining the generalized skew and flood magnitudes. Generalized least square regression equations were developed from the flood quantiles computed at 41 streamgages ( 2 streamgages in Rhode Island with reported flood quantiles were not used in the regional regression because of regulation or redundancy) and their respective basin characteristics to estimate magnitude of floods at ungaged sites. Of 55 basin characteristics evaluated as potential explanatory variables, 3 were statistically significant - drainage area, stream density, and basin storage. The pseudo-coefficient of determination (pseudo- $R^{2}$ ) indicates these three explanatory variables explain 95 to 96 percent of the variance in the flood magnitudes from 20- to 0.2-percent AEPs. Estimates of uncertainty of the at-site and regression flood magnitudes are provided and were combined with their respective estimated flood quantiles to improve estimates of flood flows at streamgages.

This region has a long history of urban development, which is considered to have an important effect on flood flows.
This study includes basins that have an impervious area ranging from 0.5 to 37 percent. Although imperviousness provided some explanatory power in the regression, it was not statistically significant at the 95-percent confidence level for any of the AEPs examined. Influence of urbanization on flood flows indicates a complex interaction with other characteristics that confounds a statistical explanation of its effects.

Standard methods for calculating magnitude of floods for given AEP are based on the assumption of stationarity, that is, the annual peak flows exhibit no significant trend over time. A subset of 16 streamgages with 70 or more years of unregulated systematic record indicates all but 4 streamgages have a statistically significant positive trend at the 95-percent confidence level; three of these are statistically significant at about the 90-percent confidence level or above. If the trend continues linearly in time, the estimated magnitude of floods for any AEP, on average, will increase by 6,13 , and 21 percent in 10 , 20 , and 30 years' time, respectively.

In 2010, new peaks of record were set at 18 of the 21 active streamgages in Rhode Island. The updated flood frequency analysis indicates the peaks at these streamgages ranged from 2- to 0.2-percent AEP. Many streamgages in the State peaked at a 0.5- and 0.2-percent AEP, except for streamgages in the Blackstone River Basin, which peaked from a 4- to 2-percent AEP.

\section{Introduction}

Following heavy persistent rains from late February through March 2010, severe flooding set or nearly set record streamflows and water levels, causing a state of emergency to be declared in many communities in Rhode Island, and a statewide presidential disaster declaration (EM-3311) on March 30, 2010. The President's action affected the emergency recovery operations in Bristol, Kent, Newport, Providence, and Washington Counties. The flood has been characterized as the worst in 200 years and is estimated to have caused damages in the hundreds of millions of dollars. As part of the recovery operations, the U.S. Department of Homeland Security's Federal Emergency Management Agency (FEMA) required analysis of the flood to assess damages and to prepare for and minimize future flood damages. 
Flood flows in Rhode Island have not been comprehensively examined since the mid-1970s (Johnson and Laraway, 1977) and then only for a limited range of basin sizes and recurrence probabilities. Flood magnitudes for a range of annual exceedance probabilities (AEPs) are an important part of determining flood prone areas and risk assessment. Floods for a given AEP magnitude are routed through hydraulic models that convert the flow into a water level on the basis of the river's capacity or conveyance. The best possible estimates of flood magnitudes for given AEP at gaged and ungaged sites is crucial for delineating flood zones, flood plain management, and designing infrastructure such as bridges and culverts so the conveyance capacity of a river is not unduly impaired.

Evaluation of the March-April 2010 peak discharge relative to the magnitude of floods over a range of AEPs is an important part of the post flood analysis and future flood management needs. The U.S. Geological Survey (USGS) entered into an agreement with FEMA in August 2010 to document and characterize the March-April 2010 flood. This report addresses the magnitude of floods at gaged and ungaged sites as part of that effort.

\section{Purpose and Scope}

The purpose of this report is to document the magnitude of flood flows over a range of AEPs at streamgages in Rhode Island and to document statewide regional equations for estimating flood flows at ungaged locations. The data used in this report were compiled from annual peak flows from 43 streamgages in Rhode Island, Connecticut, and Massachusetts through the 2010 water year. The report presents estimates of flood flows at streamgages at 20-, 10-, 4-, 2-, 1-, 0.5-, and 0.2-percent AEPs, which also have been referred to as 5-, 10-, 25-, 50-, 100-, 200-, and 500-year return interval floods, respectively. Regression equations for calculating flood flows from selected basin characteristics for the same exceedance probabilities at ungaged streams and improving the estimated flood flows at gaged sites are presented. This report describes trends in the annual peak flow data and the implications for future floods. Also discussed are the influences of urbanization and the limitations of the study.

\section{Study Area}

The study area includes selected streamgages across Rhode Island and from eastern Connecticut and south-central and southeastern Massachusetts (fig. 1). Streamgages outside of the Rhode Island provide additional information that is representative of the hydrologic region, which can improve the analysis of flood magnitudes in Rhode Island.

Southern and eastern Rhode Island, southern Connecticut, and eastern Massachusetts are in the Coastal Lowland physiographic province of New England (Denny, 1982), which is characterized by low topography ranging in elevation from sea level to several hundred feet (fig. 1). Central and northwestern Rhode Island, northeastern Connecticut, and central Massachusetts are in the Central Uplands physiographic province of New England. This region is characterized by gently rolling hills with more incised valleys. The maximum elevation in the region is about 610 feet ( $\mathrm{ft}$ ).

Climate in the basin is classified as moist continental (National Oceanic and Atmospheric Administration, 2002) with a mean annual precipitation of about 46 inches that is normally evenly distributed throughout the year. Mean annual temperature is about $50^{\circ} \mathrm{F}$ in the region. Surficial geology consists of mainly glacial stratified deposits along the major river valleys and glacial till or exposed bedrock in the upland areas.

Land cover in the region ranges from highly developed in and near major metropolitan centers such as Providence, RI, to predominantly forested (fig. 2). Most developed areas are in eastern Rhode Island and Massachusetts, the Connecticut Valley (to the west), and coastal areas. Land cover and other characteristics vary by basin and are discussed in greater detail in the section describing basin characteristics used to develop region flood flow equations.

Hurricanes, remnants of hurricanes, and storms that never developed to hurricane strength are major causes of floods in southern New England. The National Oceanic and Atmospheric Administration (NOAA; undated) online tool for historical hurricane tracks indicates that 50 hurricanes, tropical storms, tropical depressions, and extratropical storms have passed within a 75 mile radius of central Rhode Island from 1851 through 2008 (fig. 3). These storms typically originate in the central Atlantic and follow a track along the eastern United States up through New England. The hurricane tracking program lists 24 storms that passed through the region since 1904 when streamflow data were first collected in the area; 20 of these occurred since 1944 when streamgages have been in more widespread operation.

\section{Previous Studies}

Major storms of New England from 1635 through the late 1800s have been summarized by Perley (1891); however, most accounts of these historical events focused on damages to sailing ships and harbors that were the main livelihood of communities at that time. From these accounts, the types of storms and frequency can be inferred but little information is given on the physical dimensions of storms, such as the magnitude of the peak flow or depth of flooding. More specific accounts of the magnitude of large floods in Rhode Island and other affected areas have been described by Kinnison (1930) for the 1927 flood and limited information on major floods prior to the 1927, Grover (1937) for the flood of 1936, Paulsen and others (1940) for the 1938 flood, Bogart (1960) for 1955 flood, Wood and others (1970) for the March 1968 flood, and Parker and others (1998) for the June 1998 flood. These accounts summarize streamflow information that was available at the time and indirect measurements of peak flows made following the floods. This usually entailed a hydraulic analysis made from high water marks surrounding a channel structure, such as a low-head dam, or a channel constriction, such as a bridge opening. 


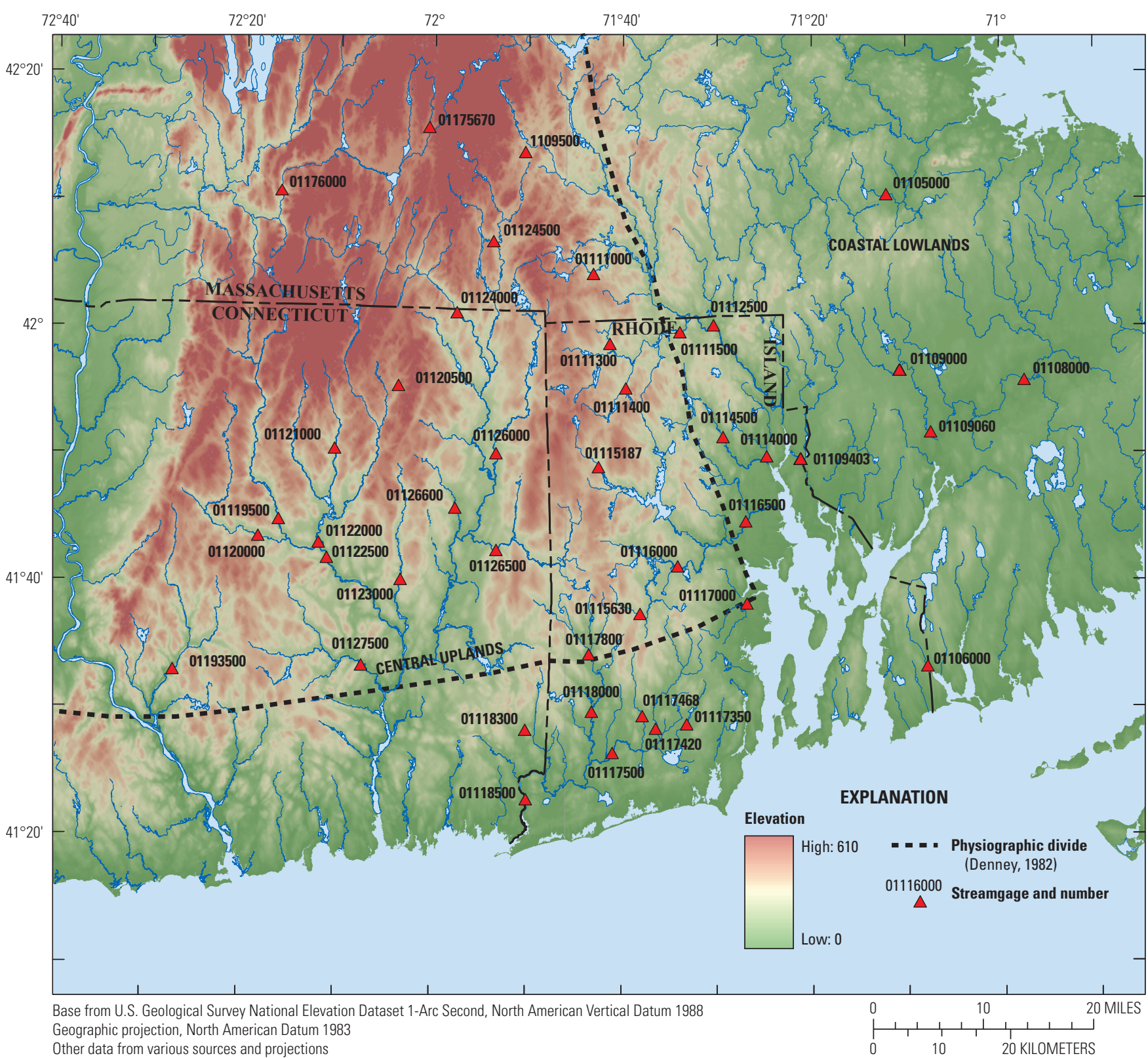

Figure 1. General area and selected streamgages used in the Rhode Island flood frequency study. 


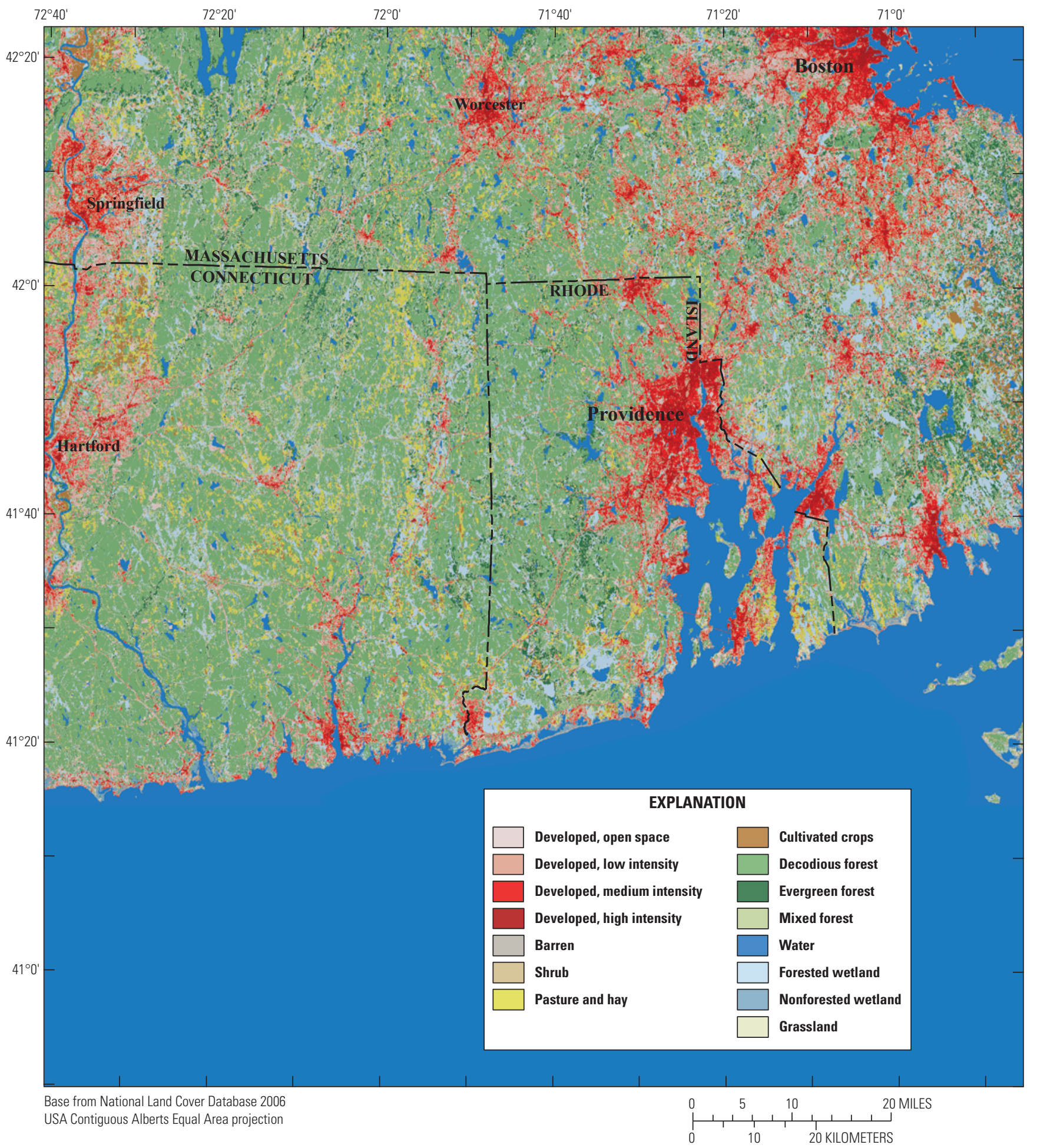

Figure 2. Land cover in the study area in Rhode Island, Connecticut, and Massachusetts from the 2006 National Land Cover Database. 


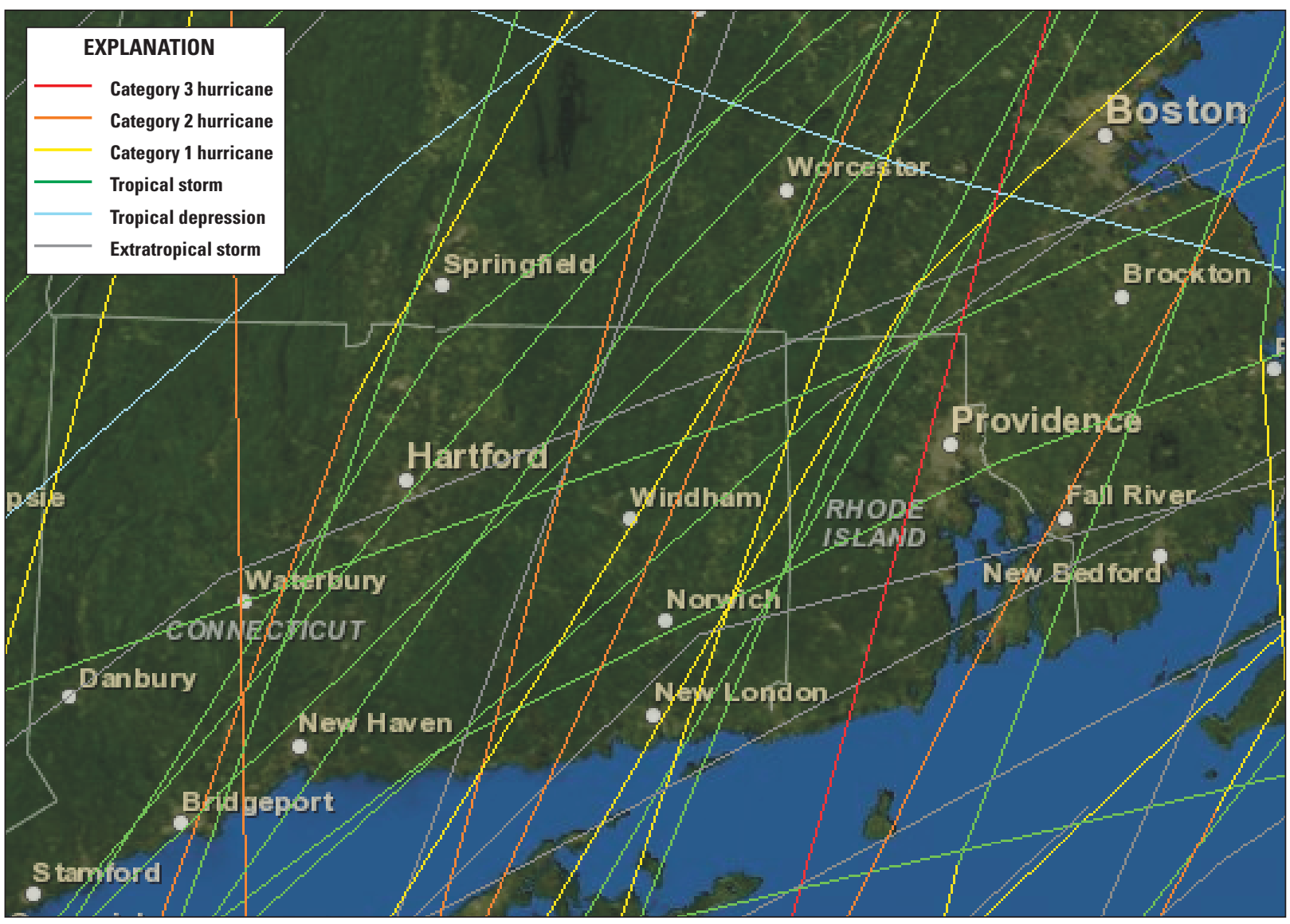

Image from National Oceanic and Atmospheric Administration Historical Hurricane Tracks at http://www.csc.noaa.gov/hurricanes

Figure 3. Hurricane and hurricane related storm tracks from 1851 through 2008 in and near Rhode Island.

Major floods of New England by Thomson and others (1964) summarized major events up to the early 1960s from actual records, including those previously mentioned, and from other sources, such as newspaper stories and accounts by local residents. The earliest flood reported in Rhode Island was from the Providence Gazette of January 13, 1770, for Pawtuxet River and other rivers- “*** a great flood $* * *$ many Mills, Bridges, etc. carried away. $* * *$ Rivers higher than they have been known these 30 years, some say 50." (Thomson and others, 1964, p. M10). Similar to the description of storms of New England by Perley (1891), Thomson and others (1964) accounts of flooding often lack sufficient detail to provide information on the physical dimensions of the storm that could be used in flood frequency analysis.

The first regionalized flood flow estimates for New England were published by the U.S. Army Corps of Engineers (USACE) in 1958. The USACE study provided different frequency curves for hurricane and nonhurricane floods and emphasized the difficulty of estimating the true frequency of large floods. The study concluded that the floods of 1927,
1936, and 1955 in New England were rare events. Mixed population distributions for nonhurricane and hurricane related events at selected streamgages in Massachusetts were also found by Murphy (2001a,b). One limitation of a mixed population distribution analysis is the number of floods of hurricane origin. Moreover, the record 2010 flood, the largest flood in most parts of Rhode Island, was not of hurricane origin and, therefore, not associated with the largest flood events.

Benson (1962) evaluated floods and methods for computing the magnitude of floods in the United States for frequencies ranging from 1.2 to 300 years. Green (1964) developed regional flood frequency curves for the United States, of which Rhode Island would be included in the North Atlantic Slope basins that covered Maine to Connecticut. The report by Green contains a compilation of peak flow data through the 1960 water year and frequency curves for floods for a given exceedance probability to drainage area by subregions.

In 1977, Johnson and Laraway published flood flow equations for Rhode Island for small rural basins less than 10 square miles $\left(\mathrm{mi}^{2}\right)$ in area. The equations were developed for estimating the magnitude of 50- and 20-percent AEPs 
floods (2- and 5-year floods) from 38 streamgages using annual peak flow records for the 1966-71 water years. Regression equations for estimating flood flows at ungaged sites were developed that use basin area, mean basin elevation, and forest cover as explanatory variables. When the National Flood Frequency (NFF) software program was introduced in 1994 (Jennings and others, 1994) the Rhode Island flood flow equations developed by Johnson and Laraway (1977) were incorporated into the database along with 10-, 4-, and 2-percent AEP flood flows that were estimated from the 50-percent AEP using factors presented by Green (1964). Comparison of flood records for the long term (1941-67) and the short term (1966-71) suggest that the extrapolated values should include an additional adjustment coefficient of 0.79 to correct for the short-term record. Estimates for extreme floods (0.2-percent AEP) were also incorporated into NFF by linear interpolation as described by Thomas and Kirby (2002).

\section{Data Compilation}

Data from the USGS National Water Information System (NWIS) peak-flow database (U.S. Geological Survey, 2012) were initially compiled for 84 streamgages. This initially included all streamgages in Rhode Island with a record for 9 or more years (42 total) and selected streamgages in Connecticut (28 streamgages) and Massachusetts (14 streamgages) that were screened for their proximity to Rhode Island as well as for regulation, record length, and quality. Many of the streamgages were removed from further analysis because of short record length, regulation, or suspect data quality. Of the initial 84 streamgages, 40 were used in the regional skew analysis - 17 in Rhode Island, 14 in Connecticut, and 9 in Massachusetts (fig. 1; table 1). The development of the regional regression equations included Adamsville Brook at Adamsville, RI (01106000), which was not used in the regional skew analysis because the record is from a relatively dry period, which caused an uncharacteristic large negative skew.

Magnitudes of floods for select AEPs were determined at the 41 streamgages used in the regional regression analysis and at long-term streamgages at Pawtuxet River at Cranston, RI (01116500), and Wood River near Arcadia, RI (01117800); these two streamgages were not used in the regional skew or regression analysis, however. Pawtuxet River at Cranston is regulated by the Scituate Reservoir and is not suitable for use in a regional analysis. Wood River near Arcadia is highly correlated with the downstream streamgage at Hope Valley (01118000) and is considered redundant. In statistical analyses, redundant sites incorrectly represent information in a regional context because they are not considered independent observations due to the fact that they share similar basin characteristics and hydrologic responses (Gruber and Stedinger, 2008).
Some streamgages are affected by flood control structures designed to decrease peak flows - Little River near Oxford, MA (01124500), Quinebaug River at Quinebaug, CT (01124000), Natchaug River at Willimantic, CT (01122000), and Shetucket River near Willimantic, CT (01122500). Flood control structures were built after these streamgages were in operation between 19 and 28 years; thus, these sites still have a sufficient period of unregulated flow that can be used in the flood frequency analysis. Unregulated annual peak flows at these streamgages were estimated after flood control structures were built using record extension methods. Annual peak flows also were estimated at relatively short-term streamgages and at long-term streamgages that were discontinued for short periods. The record extension provides the longest period possible for the flood frequency analysis.

\section{Record Extension}

Annual peak flow records were extended using a mathematical procedure developed by Hirsch (1982) known as maintenance of variance extension (MOVE). The method maintains the mean and variance of two streamgage records to extend the short-term record with the long-term streamgage (index station). MOVE is applied to the logarithms of the concurrent annual peaks of the two streamgage records.

Although the extended record analysis can potentially improve the regional skew estimate to better reflect long term conditions, it can also introduce increased inter-streamgage correlation by repeated use of an index station. Records were extended at 34 of the 84 streamgages initially selected. However, because the number of suitable index stations is limited, record extension was limited to 22 streamgages used in the skew and regression analyses (table 2) so that an index station was used no more than four times. Typically, an index station was used no more than twice to minimize inter-streamgage correlation in subsequent statistical analysis. Streamgages with extended record were selected on the basis of the length of record extended, the quality of the record extension, the number of times an index station was used, and the value of the streamgage in the analysis. Selection of extended record streamgages was generally made on the basis of the least amount of extended record and the greatest number of concurrent peaks as well as the best MOVE fit determined from the correlation coefficient and the root mean square error (RMSE). Several index streamgages were tested to determine the best streamgage to use for the record extension.

The index station record generally overlaps the shortterm record and most concurrent peaks were related to the same event. Correspondingly, the number of concurrent peaks is generally equal to the length of the short-term record, but if the records do not overlap or if the annual peaks are not related to the same event, then the number of concurrent peaks was less. Concurrent records ranged from 11 to 65 years and averaged 34 years. Scatterplots indicate that the relation between the base 10 logarithms $\left(\log _{10}\right)$ transformed peak 


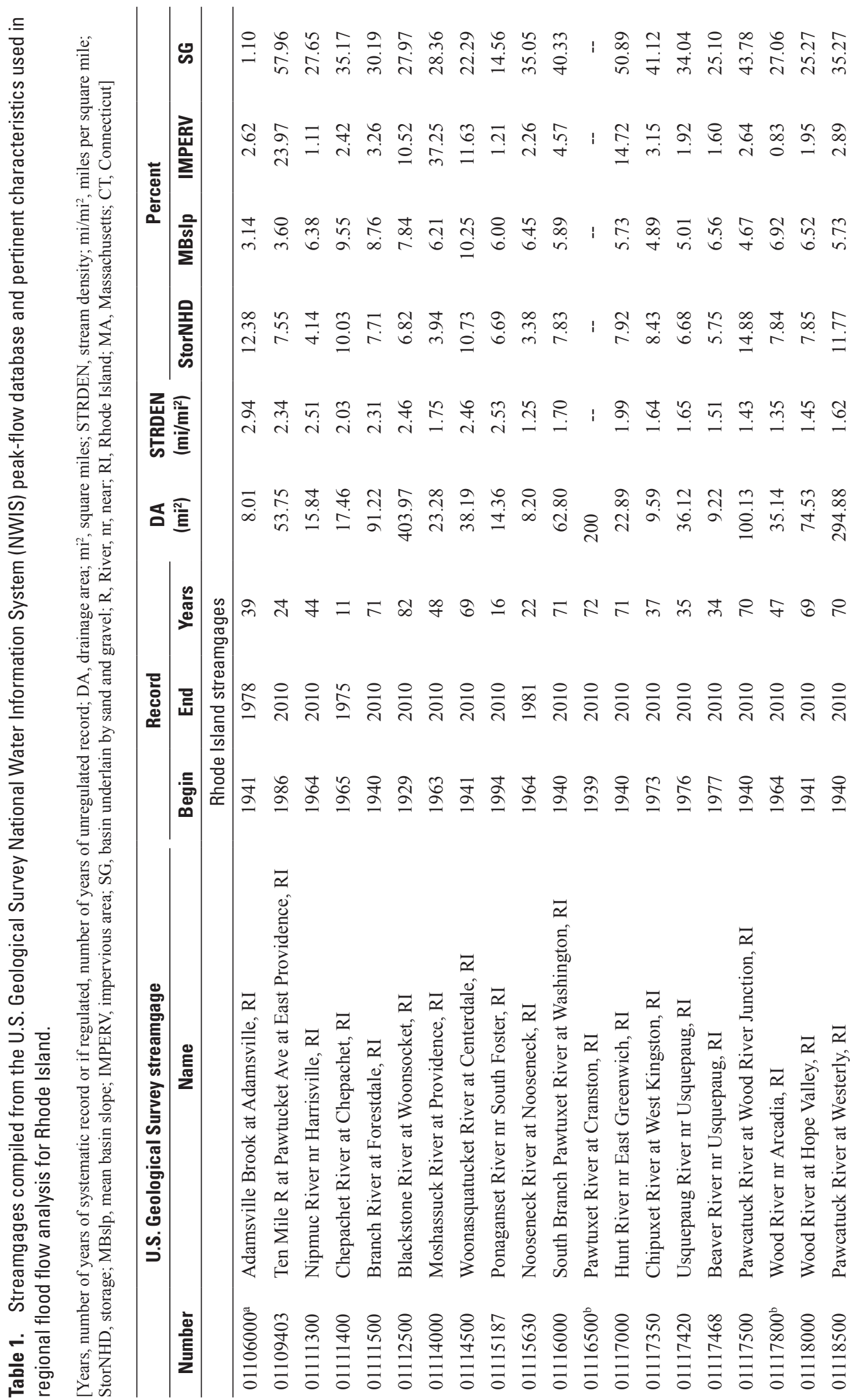




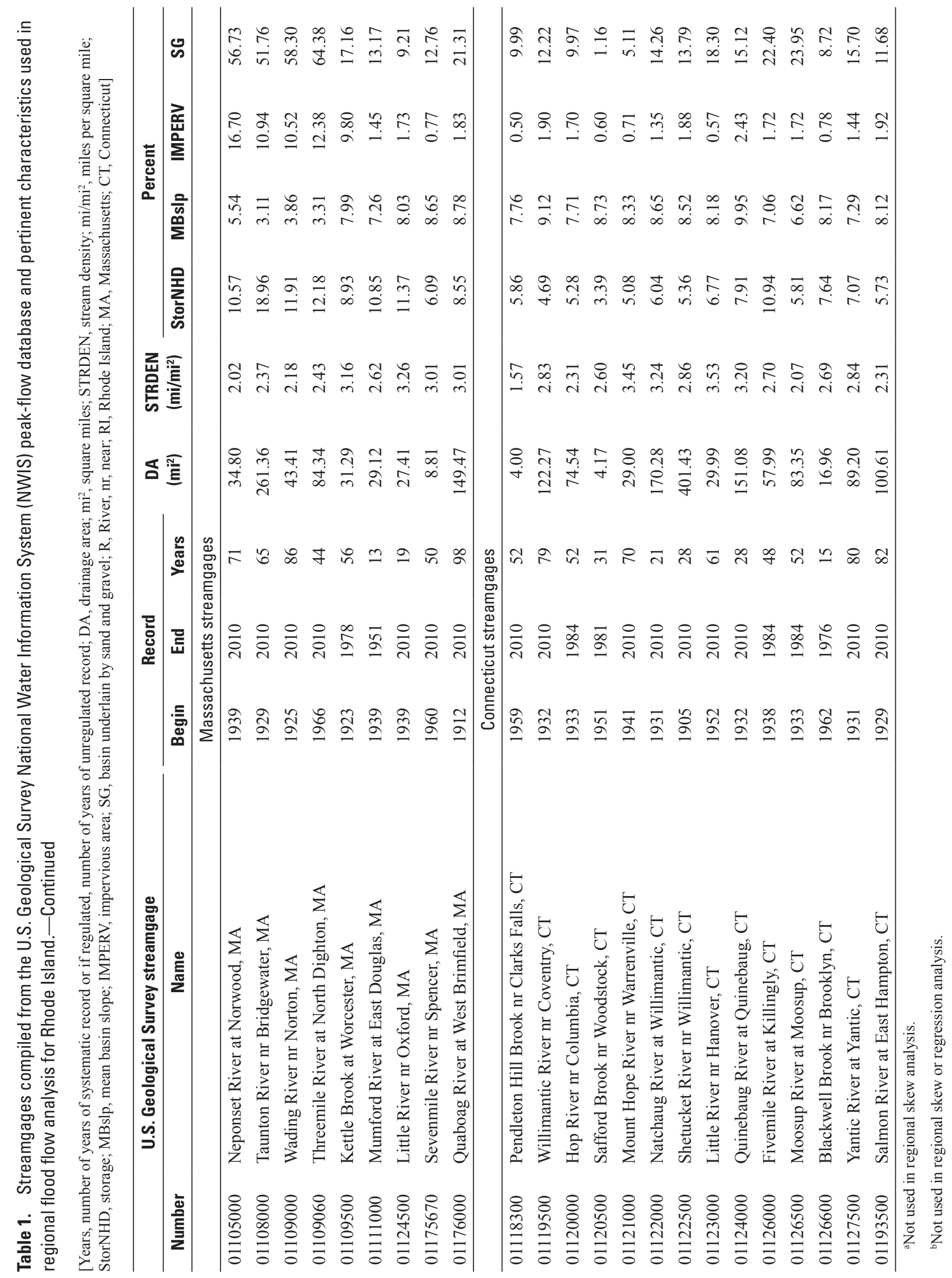


Table 2. Streamgages used in the flood frequency analysis with extended record made with the maintenance of variance extension (MOVE).

[RI, Rhode Island; MA, Massachusetts; CT, Connecticut; R, River; Ave., Avenue; nr, near]

\begin{tabular}{|c|c|c|c|c|c|}
\hline \multicolumn{2}{|r|}{ U.S. Geological Survey streamgage } & \multirow{2}{*}{$\begin{array}{c}\text { Number of } \\
\text { concurrent } \\
\text { peaks }\end{array}$} & \multirow{2}{*}{$\begin{array}{c}\text { Index } \\
\text { streamgage }\end{array}$} & \multicolumn{2}{|c|}{ Extended record } \\
\hline Number & Name & & & $\begin{array}{l}\text { Correlation } \\
\text { coefficient }\end{array}$ & $\begin{array}{l}\text { Total } \\
\text { years }\end{array}$ \\
\hline \multicolumn{6}{|c|}{ Rhode Island streamgages } \\
\hline 01111300 & Nipmuc River near Harrisville, RI & 44 & 01111500 & 0.95 & 71 \\
\hline 01111400 & Chepachet River at Chepachet, RI & 11 & 01111500 & 0.86 & 71 \\
\hline 01114000 & Moshassuck River at Providence, RI & 13 & 01114500 & 0.85 & 69 \\
\hline 01115187 & Ponaganset River near South Foster, RI & 16 & 01111500 & 0.95 & 71 \\
\hline 01115630 & Nooseneck River at Nooseneck, RI & 22 & 01111500 & 0.84 & 70 \\
\hline 01117350 & Chipuxet River at West Kingston, RI & 37 & 01111500 & 0.92 & 71 \\
\hline 01117420 & Usquepaug River near Usquepaug, RI & 35 & 01117500 & 0.96 & 70 \\
\hline 01117468 & Beaver River near Usquepaug, RI & 35 & 01117500 & 0.94 & 69 \\
\hline $1117800^{\mathrm{a}}$ & Wood River near Arcadia, RI & 47 & 01118000 & 0.95 & 69 \\
\hline \multicolumn{6}{|c|}{ Massachusetts streamgages } \\
\hline 01108000 & Taunton River near Bridgewater, MA & 65 & 01109000 & 0.85 & 85 \\
\hline 01109060 & Threemile River at North Dighton, MA & 44 & 01109000 & 0.98 & 85 \\
\hline 01109403 & Ten Mile R at Pawtucket Ave. at East Providence, RI & 24 & 01109000 & 0.97 & 85 \\
\hline 01111000 & Mumford River at East Douglas, MA & 13 & 01109000 & 0.92 & 71 \\
\hline 01175670 & Sevenmile River nr Spencer, MA & 50 & 01176000 & 0.89 & 97 \\
\hline \multicolumn{6}{|c|}{ Connecticut streamgages } \\
\hline 01118300 & Pendleton Hill Brook near Clarks Falls, CT & 52 & 01118000 & 0.88 & 69 \\
\hline 01120000 & Hop River near Columbia, CT & 52 & 01193500 & 0.91 & 78 \\
\hline 01120500 & Safford Brook near Woodstock, CT & 30 & 01121000 & 0.87 & 70 \\
\hline 01122000 & Natchaug River at Willimantic, CT & 20 & 01119500 & 0.94 & 80 \\
\hline 01122500 & Shetucket River near Willimantic, CT & 20 & 01119500 & 0.95 & 87 \\
\hline 01124000 & Quinebaug River at Quinebaug, CT & 28 & 01119500 & 0.92 & 92 \\
\hline 01126000 & Fivemile River at Killingly, CT & 33 & 01123000 & 0.84 & 74 \\
\hline 01126500 & Moosup River at Moosup, CT & 52 & 01127500 & 0.86 & 78 \\
\hline 01126600 & Blackwell Brook near Brooklyn, CT & 15 & 01123000 & 0.97 & 59 \\
\hline
\end{tabular}

${ }^{\text {a}}$ Streamgage not used in regional skew or regression analyses, but flood quantiles report for site.

discharges is linear. Correlation coefficients between the shortand long-term streamgage records ranged from 0.84 to 0.98 with an average of 0.91 .

The systematic peak flow records used in the statistical analysis ranged from 11 to 98 years with average length of 51 years prior to record extension. After records were extended at 22 of the 40 streamgages used in the regional skew analysis, record length ranged from 56 to 98 years with an average length of 76 years. In effect, this represents the annual peak flows and the corresponding conditions that produced those peaks from about 1934 to 2010 for developing a regional skew. Streamgages with extended records, on average, had about 44 years of systematic record and about 34 years of extended record.

\section{Historic Data}

Historic data are peak flows or stages, or both, that are outside the period of continuous record, also referred to as the systematic record. Historic peaks in the USGS peakflow database are typically large infrequent events where an effort was made to quantify the flood prior to an established streamgage. Sometimes this information is also collected after a streamgage is discontinued for later use in flood frequency studies.

Seven of the selected streamgages used in this study have one or more historic peaks from the 1927, 1936, and 1938 water years (table 3 ). Historic data used in this study were at long-term streamgages that began operation following the 
Table 3. Streamgages with historic records used in the study.

[--, no data in peak-flow file; stage, stage only; discharge, in cubic feet per second; years are water years; RI, Rhode Island; CT, Connecticut]

\begin{tabular}{|c|c|c|c|c|c|c|c|c|c|}
\hline \multicolumn{2}{|r|}{ U.S. Geological Survey streamgage } & \multicolumn{2}{|c|}{$\begin{array}{l}\text { Systematic } \\
\text { record }\end{array}$} & \multicolumn{4}{|c|}{ Historic record peak discharge } & \multicolumn{2}{|c|}{$\begin{array}{c}\text { Systematic } \\
\text { record peak }\end{array}$} \\
\hline Number & Name & Begin & End & 1927 & 1936 & 1938 & Rank & Discharge & Year \\
\hline 01111500 & Branch River at Forestdale, RI & 1940 & 2010 & -- & 5,800 & -- & 2 & 6,290 & 2006 \\
\hline 01118000 & Wood River at Hope Valley, RI & 1941 & 2010 & -- & 1,540 & -- & 8 & 5,470 & 2010 \\
\hline 01118500 & Pawcatuck River at Westerly, RI & 1940 & 2010 & 6,300 & 3,150 & Stage & 3,20 & 10,800 & 2010 \\
\hline 01114500 & Woonasquatucket River at Centerdale, RI & 1941 & 2010 & -- & 1,000 & -- & 13 & 1,750 & 2010 \\
\hline 01116000 & South Branch Pawtuxet River at Washington, RI & 1940 & 2010 & -- & 1,810 & -- & 4 & 5,480 & 2010 \\
\hline 01117000 & Hunt River near East Greenwich, RI & 1940 & 2010 & -- & -- & Stage & -- & 2,420 & 2010 \\
\hline 01123000 & Little River near Hanover, CT & 1952 & 2010 & -- & 1,450 & 2,100 & 18,4 & 2,964 & 1978 \\
\hline
\end{tabular}

major flood of 1938; most historic data were obtained after the 1936 flood. These data were determined by indirect measurements, such as flow over a dam, slope area, or contracted opening methods, using high water marks obtained following the flood. Indirect discharge measurements are subject to large uncertainties with a \pm 20 percent error generally considered a good measurement. Although the historic peaks are large in magnitude, they are generally well below the largest systematic record peak (table 3 ). The historic peak discharges ranked from second to the 20th highest peak of record and are generally appreciably smaller than the largest peak of record. Historic stage only records are believed to be caused by a tidal surge or are otherwise unrelated to the stage discharge relation at the streamgage and could not be used.

As previously described, larger historic peaks likely occurred but information on these events is qualitative and predates most efforts to quantify the magnitude of the event. One exception was found in the flood insurance study for the City of Warwick (Federal Emergency Management Agency, 1981), which states:

"On February 11-14, 1886, a flood known as the greatest ever on the main stem Pawtuxet River resulted in 7 to 8 inches of rainfall over the basin augmented by snowmelt with an estimated water equivalent of 2 inches (Green, 1964). Experienced flood levels were 6 to 7 feet higher than any other known flood before or since this event. There was no record of flows on the main stem, but previous studies by the COE [U.S. Army Corps of Engineers] estimated the discharge of the river was about $14,000 \mathrm{ft}^{3} / \mathrm{s}$ in the vicinity of the present U.S. Geological Survey (USGS) gage site in Cranston."

No other information about how the 1886 flood peak was determined or reference to this event for design purposes in other areas in the region could be found.
The 1886 peak discharge is about equal to the measured 2010 flood peak at Pawtuxet River at Cranston, RI (01116500) streamgage, which is the largest recorded peak. Other supporting information on the magnitude of the 1886 flood was qualitative (Kinnison, 1930; Green, 1964; Thomson and others, 1964). Kinnison (1930) described the 1886 flood as being of such magnitude that "Records of this storm served as a basis for waterway design in this district since that time." The 1886 peak was treated as an historic peak in the flood analysis at Pawtuxet River at Cranston, RI (01116500) streamgage in this study, but it should also be noted this streamgage was not used in the regional analysis because of upstream regulation from a supply reservoir. Updated at-site flood statistics are reported for the streamgage because of flooding issues along this river. It should also be noted that the river was unregulated at the time of the 1886 flood, but the available storage in the supply reservoir was exhausted at the time of the 2010 peak (flow was going over the spillway), which indicates that the 2010 peak was minimally affected by regulation.

\section{Magnitude of Flood Flows at Streamgages}

The magnitude of floods at streamgages is typically determined from the statistical properties of the annual peak flows using guidelines developed by the Interagency Committee on Water Data (IACWD) last published in 1981 and revised in 1982, known and herein referred to as Bulletin 17B. Bulletin 17B generally recommends fitting annual peak flows at a streamgage to a log-Pearson type III (LPIII) distribution to describe the likelihood of occurrence, or the annual exceedance probability (AEP) of a flood, the procedure herein is referred to as B17B. The magnitude of the flood for a given $\mathrm{AEP}$ using $\mathrm{B} 17 \mathrm{~B}$ is computed from three properties 
of the logs of the annual peak data - the mean, the standard deviation, and the skew using the following equation:

$$
\log Q_{P}=\bar{X}+K_{P} S,
$$

where

$$
\begin{gathered}
Q_{P} \quad \begin{array}{l}
\text { is the P-percent AEP flow, in cubic feet } \\
\text { per second; }
\end{array} \\
\bar{X} \quad \begin{array}{c}
\text { is the mean of the logarithms of the annual } \\
\text { peak flows; }
\end{array} \\
K_{P} \quad \begin{array}{l}
\text { is a factor based on the skew coefficient and } \\
\text { the given percent AEP and obtained from } \\
\text { appendix } 3 \text { in Bulletin 17B; and }
\end{array} \\
S \quad \begin{array}{l}
\text { is the standard deviation of the logarithms of } \\
\text { the annual peak flows, which is a measure } \\
\text { of the degree of variation of the annual } \\
\text { values about the mean value. }
\end{array}
\end{gathered}
$$

A relatively new procedure for calculating the magnitude of flood flows from annual peak flow records, known as the expected moments algorithm (EMA), also was used in this study. The EMA also uses a LPIII distribution, but unlike the LPIII procedures outlined in B17B, which are constrained to the moments of point values, the EMA can accommodate interval data to better define the distribution characteristics of annual peak flows (Cohn and others, 1997). Interval data can represent conditions such as the potential range of annual peak flows outside of the systematic and historic record and the uncertainties around recorded peaks used in the analysis. The EMA then uses an iterative procedure to recompute the moments from the interval data starting from the systematic record moments; the algorithm converges when the newly computed moments no longer appreciably differ from the last iteration of the computed moments. If only a systematic record is used in the analysis (that is, no interval data is used) and low outliers are not present, B17B and EMA analyses produce the same result. However, the confidence intervals around the flood quantiles differ because of different methods used by each procedure (Cohn and others, 2001). The EMA is expected to replace the standard LPIII procedure in Bulletin 17B in the next update of the guidelines and was applied in this study by use of the FORTRAN program PeakfqSA (Tim Cohn, U.S. Geological Survey, written commun., March 9, 2011) and the USGS PeakFQ program version 6.0.14667.

Often peak flow records do not follow a normal distribution, which affects the shape of the frequency distribution curve and, thus, the magnitude of floods for a given exceedance probability. The asymmetry of the frequency distribution curve is measured by the station skew. A single station, especially one with a short record, typically does not provide an accurate estimate of the "true" skew. To compensate, Bulletin 17B recommends weighting the station skew with a generalized skew computed regionally from many streamgages to better utilize available information.

\section{Skew Coefficient}

Skews are highly influenced by the leverage of observations in the upper and lower tails of the annual peak flow record. Negative skews indicate that the left side of the probability distribution function is longer than the right side and that the bulk of the values lie to the right of the mean. In other words, smaller annual peaks outweigh the larger annual peaks, resulting in smaller computed flood flow for a given exceedance probability than records that are skewed to the right. The extent of this effect becomes more evident as the exceedance probability decreases. Bulletin 17B gives specific procedures for testing and handling high and low outliers because of their effect on the statistical properties of the data. It should be noted that skews are computed from the average cubed deviations from the mean of the logarithms of annual peak flows; thus, the shorter the record, the greater the likelihood that the skew will be leveraged by values at the tails of the distribution.

\section{Low Outlier Adjustment}

When streamgage records are skewed to the left by low outliers, the magnitude of flood flows are leveraged downward. Because the primary interest of a flood frequency analysis is the magnitude of floods that occur infrequently (AEP of 20 percent or less) Bulletin 17B outlines a conditional probability adjustment for low outliers before further analysis is made. Low outliers were initially detected and conditioned using the PeakFQ software (Flynn and others, 2006), which uses procedures described in Bulletin 17B; however, the test detects and conditions only the lowest outlier in the dataset. Single low outliers were detected in 5 of 40 streamgages used in the regional skew analysis (table 4).

Cohn and others developed a test to detect multiple low outliers (Tim Cohn, U.S. Geological Survey, written commun., March 3, 2011) using a modified version of the Grubbs-Beck test (Grubbs and Beck, 1972), referred to as the multiple Grubbs-Beck (MGB) test. The MGB test was used to check all streamgage records used in the analysis. Low outliers were detected at the same streamgages as previously detected by PeakFQ, but multiple low outliers were detected at Taunton River near Bridgewater, MA (01108000), at Moshassuck River in Providence, RI (01114000), and at Adamsville Brook in Adamsville, RI (01106000) at the 95-percent confidence level. Inspection of the Taunton River annual peak distribution indicates only a single low outlier was warranted, and only a single low outlier adjustment was used in subsequent analysis. Six low outliers were detected in the Adamsville Brook record that was conditioned in the at-site analysis using procedures in the EMA, which treats low outliers differently than the procedure outlined in Bulletin 17B. The EMA uses the MGB test to detect potentially influential low peaks (PILPs) and uses an iterative process to find the cutoff threshold along the LPIII distribution where PILPs no longer significantly affect the probability distribution. Annual peaks below that threshold are 
Table 4. Outliers detected in peak-flow database for streamgages used in the flood-frequency analysis.

[Years of record applies to the systematic record; Thres-H, discharge threshold determined by Bulletin 17B test for high outliers; Thres-I, smallest retained observation determined by the modified Grubbs-Beck test; WY, water year in which outlier was detected; Q, magnitude of the outlier, in cubic feet per second $\left(\mathrm{ft}^{3} / \mathrm{s}\right)$; --, no outliers detected; streamgages with no detected outliers are not listed; RI, Rhode Island; CT, Connecticut; MA, Massachusetts]

\begin{tabular}{|c|c|c|c|c|c|c|c|c|}
\hline \multicolumn{2}{|r|}{ U.S. Geological Survey streamgage } & $\begin{array}{l}\text { Years of } \\
\text { record }\end{array}$ & \multicolumn{3}{|c|}{ High outliers } & \multicolumn{3}{|c|}{ Low outliers } \\
\hline \multicolumn{9}{|c|}{ Rhode Island streamgages } \\
\hline 01112500 & Blackstone River at Woonsocket, RI & 82 & 27,010 & 1955 & 32,900 & 1,970 & -- & -- \\
\hline \multirow[t]{2}{*}{01114000} & Moshassuck River at Providence, RI & 47 & 2,110 & -- & -- & 667 & $\mathrm{~b}$ & -- \\
\hline & (extended record) & & & & & & 1949 & 403 \\
\hline 01116000 & South Branch Pawtuxet River, RI & 70 & 3,570 & 2010 & 5,480 & 245 & -- & -- \\
\hline 01116500 & Pawtuxet River at Cranston, RI & 71 & 7,700 & 2010 & 14,200 & 695 & -- & -- \\
\hline 01117000 & Hunt River near East Greenwich, RI & 70 & 1,750 & 2010 & 2,380 & 114 & -- & -- \\
\hline 01117350 & Chipuxet River at West Kingston, RI & 37 & 595 & 2010 & 748 & 50 & 1981 & 20 \\
\hline \multirow[t]{2}{*}{01117468} & Beaver River near Usquepaug, RI & 34 & 655 & 2010 & 901 & 46 & -- & -- \\
\hline & (extended record) & 69 & 554 & 2010 & 901 & 33 & -- & -- \\
\hline 01117500 & Pawcatuck River at Wood River Junction, RI & 70 & 2,400 & 2010 & 3,490 & 350 & -- & -- \\
\hline 01118000 & Wood River at Hope Valley, RI & 69 & 3,200 & 2010 & 5,470 & 460 & -- & -- \\
\hline 01118500 & Pawcatuck River at Westerly, RI & 70 & 7,620 & 2010 & 10,800 & 1,270 & -- & -- \\
\hline \multicolumn{9}{|c|}{ Connecticut streamgages } \\
\hline 01119500 & Willimantic River near Coventry, CT & 79 & 15,920 & 1955 & 24,200 & 728 & -- & -- \\
\hline \multirow[t]{3}{*}{01122000} & Natchaug River at Willimantic, CT & 21 & 17,410 & 1938 & 26,000 & 1,610 & -- & -- \\
\hline & (extended record) & 80 & 24,520 & 1955 & 36,600 & 1,370 & -- & -- \\
\hline & (extended record) & & & 1938 & 26,000 & & & \\
\hline \multicolumn{9}{|c|}{ Massachusetts streamgages } \\
\hline \multirow[t]{2}{*}{01108000} & Taunton River near Bridgewater, MA & 65 & 6,080 & -- & -- & 1,250 & 1985 & 795 \\
\hline & (extended record) & 85 & 6,577 & -- & -- & $1,736^{\mathrm{c}}$ & 1985 & 795 \\
\hline 01109500 & Kettle Brook at Worcester, MA & 56 & 3,330 & 1955 & 3,970 & 93 & -- & -- \\
\hline \multirow[t]{2}{*}{01124500} & Little River near Oxford, MA & 19 & 3,220 & 1955 & 8,340 & 66 & -- & -- \\
\hline & (extended record) & 98 & 2,890 & 1955 & 8,340 & 138 & -- & -- \\
\hline \multirow[t]{3}{*}{01175670} & Sevenmile River near Spencer, MA & 50 & 767 & - & - & 64 & 1965 & 33 \\
\hline & (extended record) & 98 & 1,180 & 1955 & 3,270 & 33 & -- & -- \\
\hline & (extended record) & & & 1938 & 1,950 & & & \\
\hline \multirow[t]{2}{*}{01176000} & Quaboag River at West Brimfield, MA & 98 & 5,480 & 1955 & 12,800 & 540 & -- & -- \\
\hline & (extended record) & & & 1938 & 8,470 & & & \\
\hline
\end{tabular}

${ }^{a}$ Water years $1965,1966,1949,1955,1951$, and 1950 with discharges of $66,74,85,87,90$, and $103 \mathrm{ft}^{3} / \mathrm{s}$, respectively.

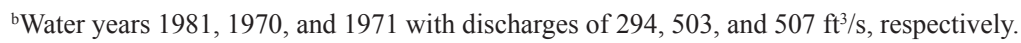

'Fifteen low outliers detected, but only the 1985 peak plotted below the probability distribution curve. 
treated as interval data that are less than the cutoff threshold value during the iterative process the EMA uses to converge on a new probability distribution. Despite the censoring of multiple PILPs at the Adamsville Brook streamgage, the EMA analysis still resulted in a large negative skew $(-0.47)$ at this site that is atypical of the region. For this reason, the skew at the Adamsville Brook streamgage was not used to develop the regional skew.

\section{High Outlier Adjustment}

High outliers were detected in most of the streamgage annual peak records by PeakFQ (Flynn and others, 2006), which uses procedures described in Bulletin 17B. Historic peak flow data for the streamgages used in this study, as previously discussed, are often appreciably less than the highest peak in the systematic record. Other historical information is qualitative and does not provide the quantitative magnitude of the flood needed to treat high outliers.

High outliers detected in the streamgage records were retained as part of the systematic record without adjustment other than adjustments made for historic peaks in the peakflow database. In some cases, when the historic peak is appreciably less than the highest peaks in the systematic record, a high outlier threshold was specified in the B17B analysis that was set equal to the computed high outlier threshold for the period of systematic record. This prevents the computed high outlier threshold with historic data being set lower than warranted by the distribution of the peak flow values when relatively small historic peaks are present in the data. However, because of the short time span between the historic data and the start of the systematic data, the high outlier threshold has little effect on the flood frequency analysis.

High outliers were detected in 20 of 40 streamgages used in the regional skew analysis (table 4). At most of these streamgages only a single high outlier was detected. Spatially plotted station skews indicate two areas with high skews (fig. 4) corresponding to high outliers that originate from the 1938, 1955, 1982, and 2010 floods (table 4). The recent 2010 flood accounted for all the high outliers in central Rhode Island. This flood resulted from a succession of low pressure systems from late February through late March that collectively produced as much as 25 inches of rain, which is more than half the total average annual rainfall. The resulting peak flows often exceeded the previously recorded peak by two to three times in the central Rhode Island area and appreciably affected 9 of the 14 streamgages used flood flow analysis in the state.

In early June 1982, a large low pressure system moved slowly into the northeast and stalled, resulting in up to 16 inches of rain during a 4-day period. The heaviest rain was in south-central Connecticut that resulted in a high outlier at Salmon River at East Hampton, CT (01193500). The event also produced high outliers at several other streamgages in this area that were not used in the final analysis in this study because of data concerns. In August 1955, back-to-back hurricanes, Connie and Diane, resulted about 20 inches of rain in a 2 week period in south-central Massachusetts, resulting in outliers at streamgages in south-central Massachusetts and north-central Connecticut. In September 1938, a large rainfall followed by a hurricane related rainfall event centered in northern Connecticut and central Massachusetts produced high outliers at three streamgages in that region. The 1938 flood was considered a major event; however, the 1938 peak has subsequently been exceeded by other peaks and is no longer detected as a high outlier at most streamgages that were in operation at the time or had an historic peak of the 1938 flood.

\section{Generalized Regional Skew}

The primary purpose of the generalized skew is to adjust the at-site skew to best reflect regional and long term conditions. Bulletin 17B recommends that generalized skews be developed from a minimum of 40 streamgages that are within a 100 mile radius of each other and have a record of at least 25 years. Skews were determined from the annual peak flow records at the 40 streamgages listed in table 1 and from subsets of these streamgages. Skews were examined to determine if geographic patterns exist, but none were found except for patterns related to high outliers previously described.

After conditioning for low outliers and historic adjustments, skews were determined from the at-site analysis of annual peak flows (table 5) following B17B methods as implemented in PeakFQ. The skew computed from records for all 40 streamgages averaged 0.567 with a standard error of estimate, also known as the root mean square error (RMSE), of 0.626. Skews and RMSEs were determined from subsets of streamgages with successively longer records greater than or equal to 25,50 , and 60 years. As the period of record increased, the number of streamgages available progressively decreased; the average skew generally increases and RMSE decreases with the increasing period of record (table 5).

The average skew and RMSE also was determined from the same 40 streamgages using the extended record at 23 streamgages as previously described after conditioning for low outliers and historic adjustments. Skews at some streamgages also were determined using the EMA to account for uncertainties in the annual peaks, better define the range of possible flows in the interval between historic and systematic data, and to censor multiple low outlier values. The accounting of data uncertainties used by the EMA is described in more detail in the section on "Quantifying Uncertainty of Annual Peaks." At several streamgages with one or more low outliers or historic values, the standalone version of the EMA (PeakfqSA; Tim Cohn, U.S. Geological Survey, written commun., March 9, 2011) differed from the skew produced by the EMA implemented in PeakFQ version 6.0.14667. At these streamgages, the skew produced by B17B as implemented in PeakFQ was used to compute the regional skew; however, the differences were small and resulted in little change in the outcome of a regional skew. 


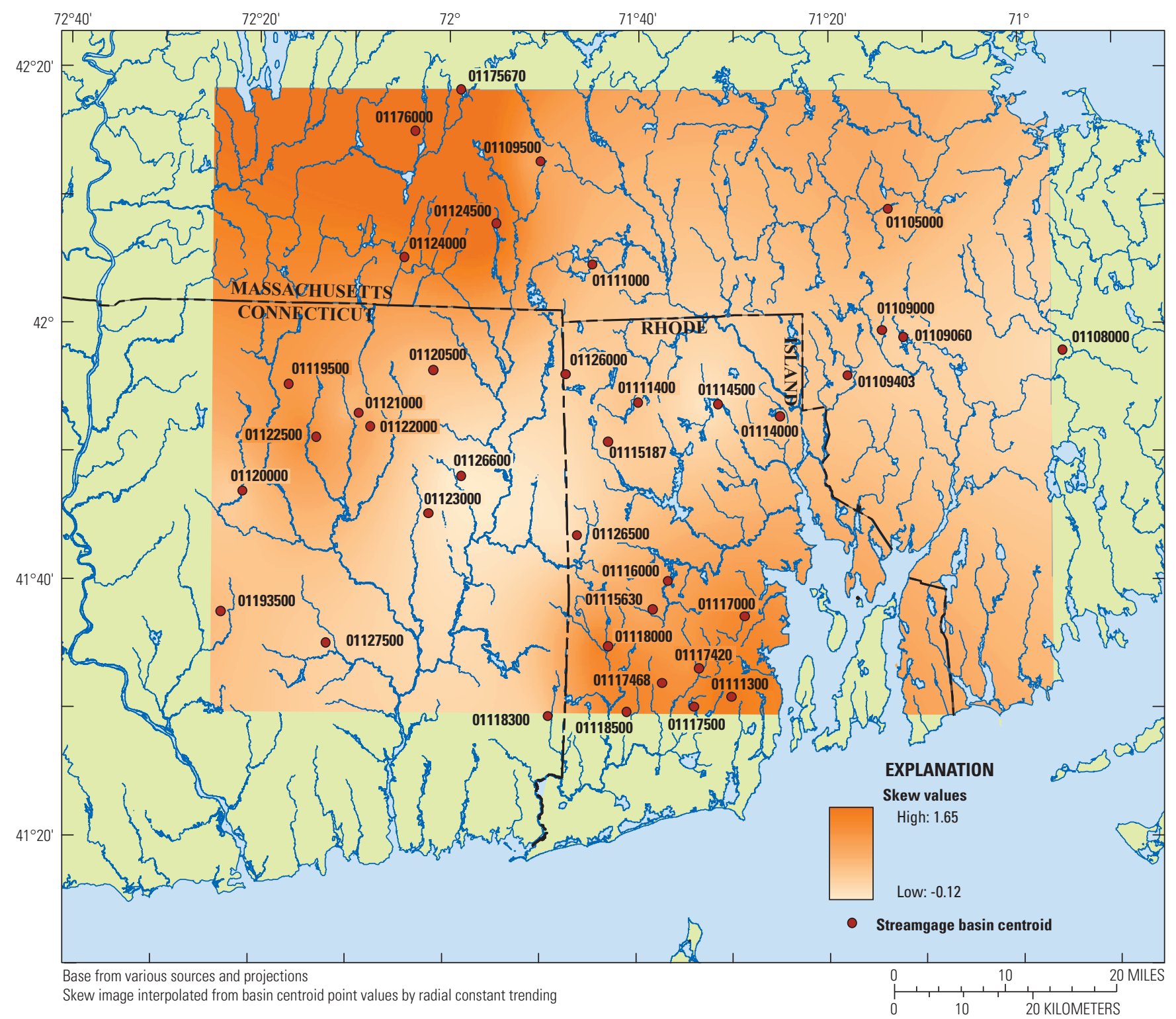

Figure 4. Streamgage skews used to develop the regional skew at selected streamgages in Rhode Island, eastern Connecticut, and south-central and eastern Massachusetts.

Table 5. Summary of generalized skew values determined for Rhode Island and nearby surrounding areas.

[RMSE, root mean square error; $\geq$, greater than or equal in reference to the length of the systematic record]

\begin{tabular}{|c|c|c|c|c|c|}
\hline \multirow{2}{*}{ Selection criterion } & \multirow{2}{*}{$\begin{array}{c}\text { Number of } \\
\text { streamgages }\end{array}$} & \multicolumn{2}{|c|}{ Record length (years) } & \multirow{2}{*}{ Skew } & \multirow{2}{*}{ RMSE } \\
\hline & & Average & Minimum & & \\
\hline All streamgages (no record extension) & 40 & 51 & 11 & 0.567 & 0.624 \\
\hline$\geq 25$ years & 29 & 60 & 28 & 0.576 & 0.555 \\
\hline$\geq 50$ years & 21 & 69 & 50 & 0.512 & 0.438 \\
\hline$\geq 60$ years & 16 & 75 & 61 & 0.603 & 0.427 \\
\hline All streamgages ( 23 with extended record) & 40 & 77 & 56 & 0.522 & 0.463 \\
\hline
\end{tabular}


The average skew of 0.52 and RMSE of 0.46 determined from 40 streamgages, 22 of which had extended record, were used to weigh the skews in the final at-site analysis of flood flows. These values are believed to best represent the generalized skew and error for the region by incorporating the largest number of streamgages and longest period possible. If the analysis were limited to streamgages with 25 or more years, as recommended in Bulletin 17B, about 24 percent of the streamgages would drop from the analysis.

The RMSE is a measure of the accuracy of the at-site skew, which is computed by the square root of the sum of the square differences between the at-site skew and the mean skew, divided by the number of sites minus one. The RMSE is used in the computation of the weighted skew and the confidence bounds of the flood magnitude in the at-site analyses. As currently implemented, the RMSE reflects sample and model error that has been separated in recent advances for computing generalized skews using Bayesian generalized least square (GLS) methods (Reis and others, 2005; Gruber and others, 2007). The Bayesian GLS methods could not be applied in this study because of time constraints; however, the robustness of the method should be considered in future flood frequency studies. It should be noted that the RMSE within the range of computed RMSE values (table 5) had only a minor effect on the flood magnitude and confidence intervals.

A larger regional skew could be warranted on the basis of the streamgages with high skews (fig. 4) associated with the four independent floods previously described. Areas minimally affected by these events and correspondingly areas of lower skews have an equal likelihood of an event of similar severity, which could justify a regional skew based on the average of the high skew values. The skew determined from the actual and extended records for the 18 streamgages with one or more high outliers averaged 0.93 (RMSE 0.37), or about 79 percent larger than the skew determined from the average skew (0.52) of the 40 streamgages. Sensitivity of the AEP flood magnitudes to the higher regional skew was evaluated for each of the 18 streamgages, which averaged 79 years in length and ranged from 56 to 98 years. Results indicate that, when the generalized skew increases from 0.52 to 0.93 , the magnitudes of 1- and 0.2-percent AEP floods increase on average by about 7 and 13 percent, respectively. Conversely, floods with a 20-percent AEP decreased on average by 0.7 percent. Magnitudes increased by less than 5 percent for 10- to 2-percent AEP floods when the regional skew increased. However, a larger regional skew will have a greater effect on the flood magnitudes at a site as the streamgage record length at the site decreases.

\section{Quantifying Uncertainty in Annual Peak Records}

At a number of streamgages used in this study, the upper end of the stage-discharge rating is defined by one or more indirect measurements of streamflow. These measurements are based on hydraulic principles of contracted openings, flow over a dam, or slope area, and field information collected following a flood on high water levels and geometry of the channel and other structures. Even the best indirect measurements are subject to large uncertainties because of the accuracy of high water marks, debris confounding the hydraulic characteristics of structures, coefficients required by the hydraulic model, and other factors. Discharge determined by indirect methods sometimes far exceeds the highest direct streamflow measurements, which are generally made with greater accuracy. When this happens, the magnitude of annual peak flows above the direct streamflow measurement is affected by the accuracy of the indirect measurement. This in turn influences the magnitude of low probability floods, which are determined in large part by the largest peaks in the record that are defined by the upper part of the stage-discharge rating and its inaccuracies.

The uncertainty of annual peak flows associated with an indirect measurement or other causes can be incorporated into the at-site analysis by uncertainty estimates around the suspect peaks using the EMA. As an example, the high flow rating at Mount Hope River near Warrenville, CT (01121000) is defined by an indirect measurement following the 1955 flood using the contracted opening method. The indirect measurement of 5,590 cubic feet per second $\left(\mathrm{ft}^{3} / \mathrm{s}\right)$ is the highest flow of record at this streamgage and is 2.6 times larger than the highest direct flow measurement of $2,150 \mathrm{ft}^{3} / \mathrm{s}$. During the 70 -year streamflow record (1941-2010), 11 systematic annual peaks were 5 to 260 percent greater than the highest measured streamflow, with a median of 27 percent larger. Examination of the high flow rating (fig. 5) indicates a bend to the right above the measured flows to draw the rating through the indirect measurement. Without the indirect measurement, the hydrologic characteristics of the site indicate that the rating would likely have been extended as a straight line on a log$\log$ scale as indicated by the red line on figure 5. Assuming the gage height for the 1955 peak is correct, the discharge estimated from the straight line rating is about 36 percent less than the indirect measurement. It should also be noted that the rating changes over time below about 1,200 ft $\mathrm{ft}^{3} / \mathrm{s}$ because of shifts in the channel control; the rating in effect at the time of the peak below $1,200 \mathrm{ft}^{3} / \mathrm{s}$ best represents the stage-discharge relation at that time.

Uncertainty estimates of annual peak flows above $2,000 \mathrm{ft}^{3} / \mathrm{s}$ were estimated on the basis of the difference between the current high flow rating (blue line) and the extrapolated straight line rating (red line) in figure 5 that were incorporated in the EMA analysis as a lower uncertainty interval (fig. 6A). The uncertainty of specified annual peak flows was only bounded by a lower threshold to reflect the difference between the ratings of the blue and red lines. Also included in the analysis was an estimated peak flow from the 1938 flood, which was listed only as a peak stage in the peak-flow database that does not appear to be relevant to the gage datum. It was assumed that stage was entered only in the peak-flow database because an indirect measurement for this flood was made far upstream of the current streamgage; the 


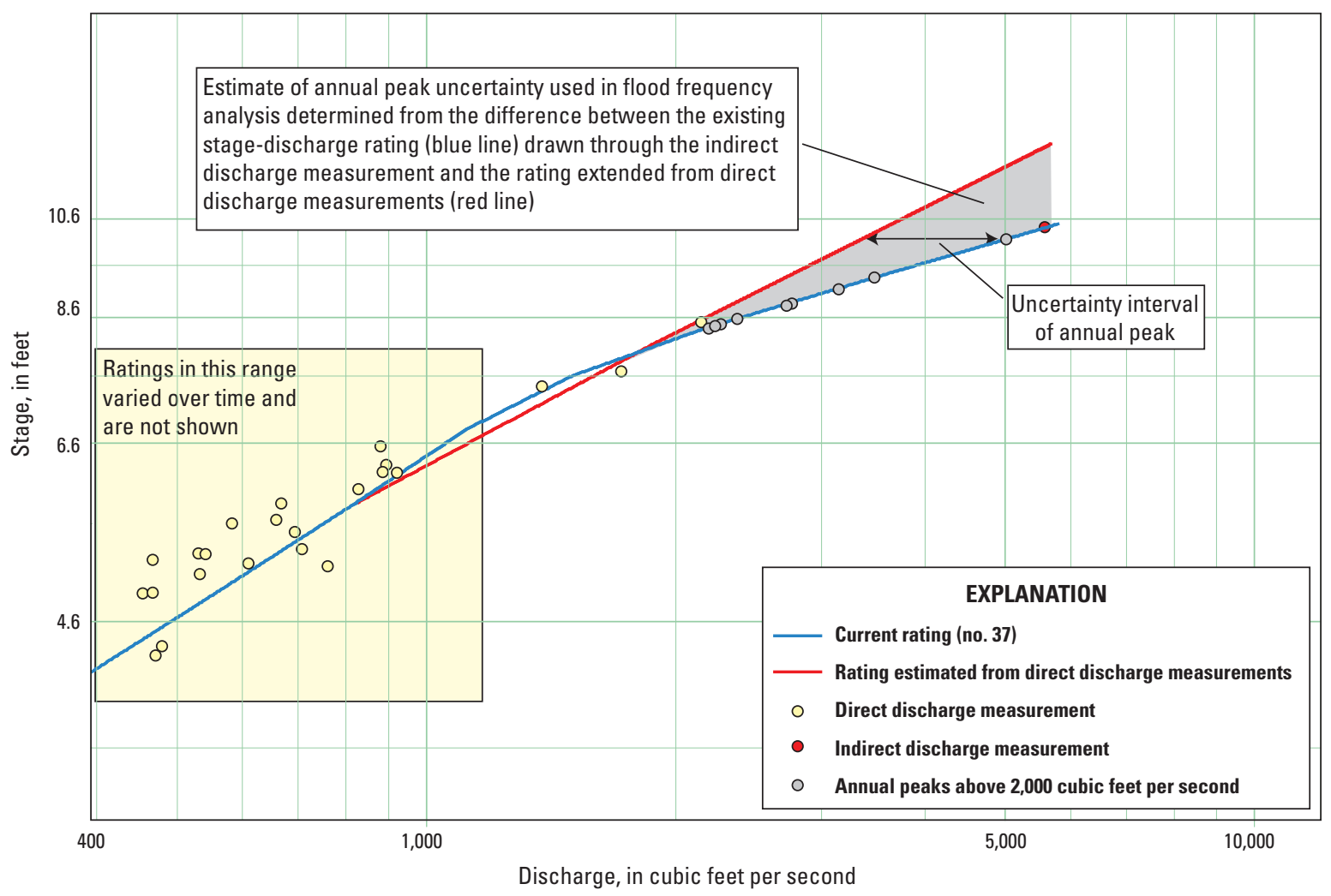

Figure 5. Upper stage-discharge rating and range of uncertainty of higher annual peak flows used in flood frequency analysis at Mount Hope River near Warrenville, CT (01121000).

drainage area at the streamgage is $28.6 \mathrm{mi}^{2}$, whereas the 1938 indirect measurement was made at a drainage area of $6.5 \mathrm{mi}^{2}$. The 1938 indirect measurement adjusted for drainage area was estimated to be $3,780 \mathrm{ft}^{3} / \mathrm{s}$ and was considered reasonable given the magnitudes of the 1938 and 1955 flood discharges at a nearby long-term streamgage (Hop River near Columbia, CT-0112000). Nevertheless, a \pm 25 percent lower and upper confidence interval was assigned to the 1938 peak discharge at Mount Hope River at Warrenville $(2,840$ and 4,720 ft $3 / \mathrm{s}$, respectively) to reflect the normal error of an indirect measurement and the drainage area difference. In addition, the period between the historic peak (1938) and the start of the systematic record (1941) was assigned a perception threshold of $2,000 \mathrm{ft}^{3} / \mathrm{s}$ (blue vertical bar; fig. 6A), which informs the EMA analysis that peak flows during this period did not exceed that threshold.

The resulting probability distribution curves (fig. 6B) indicate that the EMA begins to deviate from the B17B curve at about the 20-percent exceedance probability, and the difference increases as the exceedance probability decreases. The EMA fitted curve is about equal to the lower 95-percent confidence B17B curve at the lower exceedance probabilities. Flood magnitudes calculated by the EMA that incorporate some of the data uncertainties at the Mount Hope River streamgage decreased relative to the flow computed by B17B from about 4 to 18 percent for the 10- to 0.2 -percent exceedance probability, respectively (table 6). However, it should be noted that, despite the decrease in the fitted distribution curves from the B17B to the EMA, the magnitude of floods at the upper confidence level for lower probability floods was appreciably larger for the EMA than for the B17B distribution. The magnitudes of the upper confidence level EMA flows were about 6 to 60 percent larger for the 10- to 0.2-percent exceedance probability, respectively, relative to the $\mathrm{B} 17 \mathrm{~B}$ upper confidence level (fig. 6B; table 6).

Similar hydrologic judgment was used to determine uncertainties at other streamgages used in the analysis. Of the 43 streamgages used, uncertainty limits were specified at 20 streamgages for similar reasons described in the Mount Hope River example. The uncertainties of extended record peak flows were sometimes assigned on the basis of the quality of fit between the short-term streamgage and the index station, which in some cases were compounded by the uncertainties of both streamgage records. On average, the skew decreased by about 16 percent at streamgages where uncertainties were applied in the EMA analysis compared with the skew determined from B17B analysis. 
A. Annual peak flow and historical flows

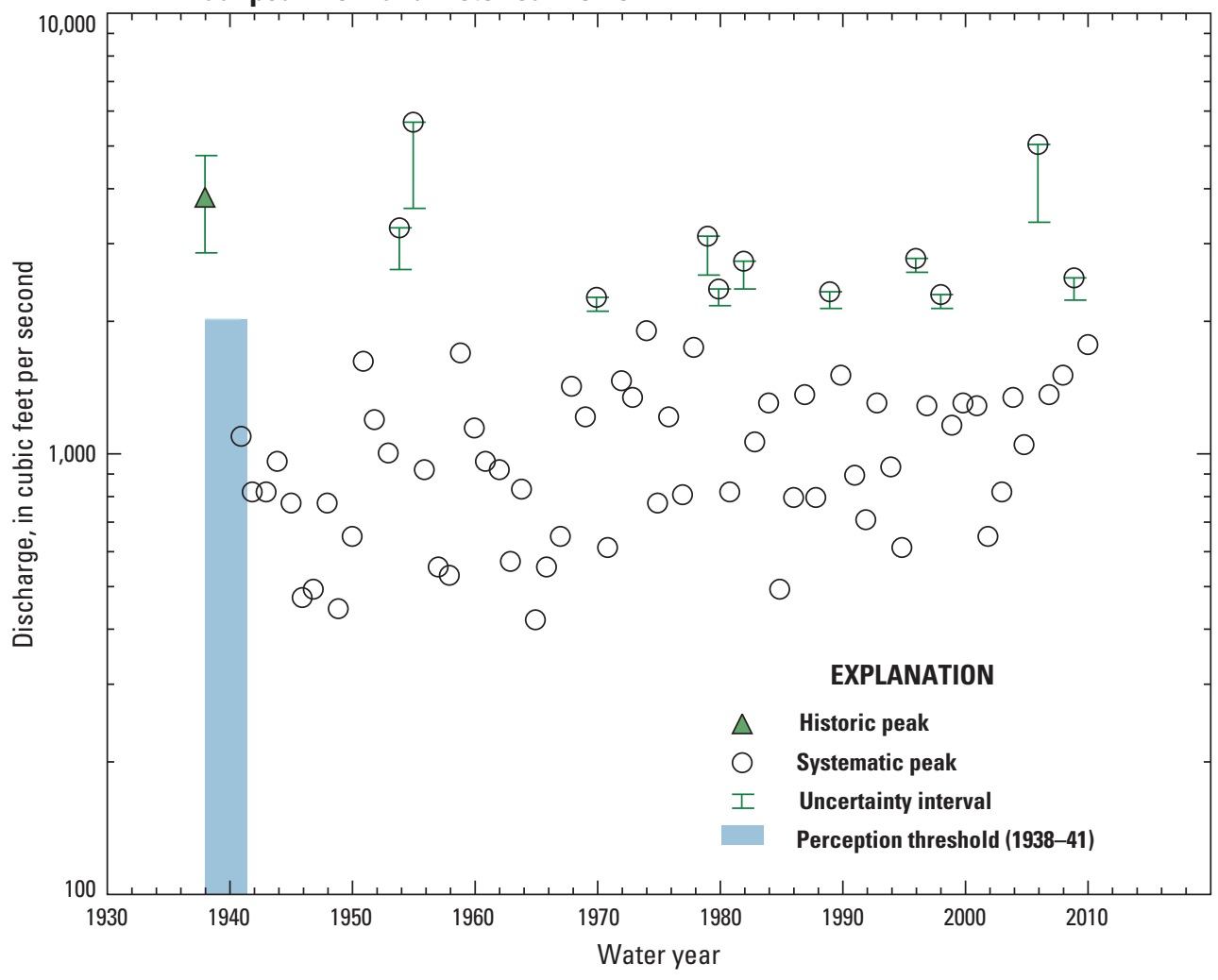

B. Flood-frequency estimates and uncertainty

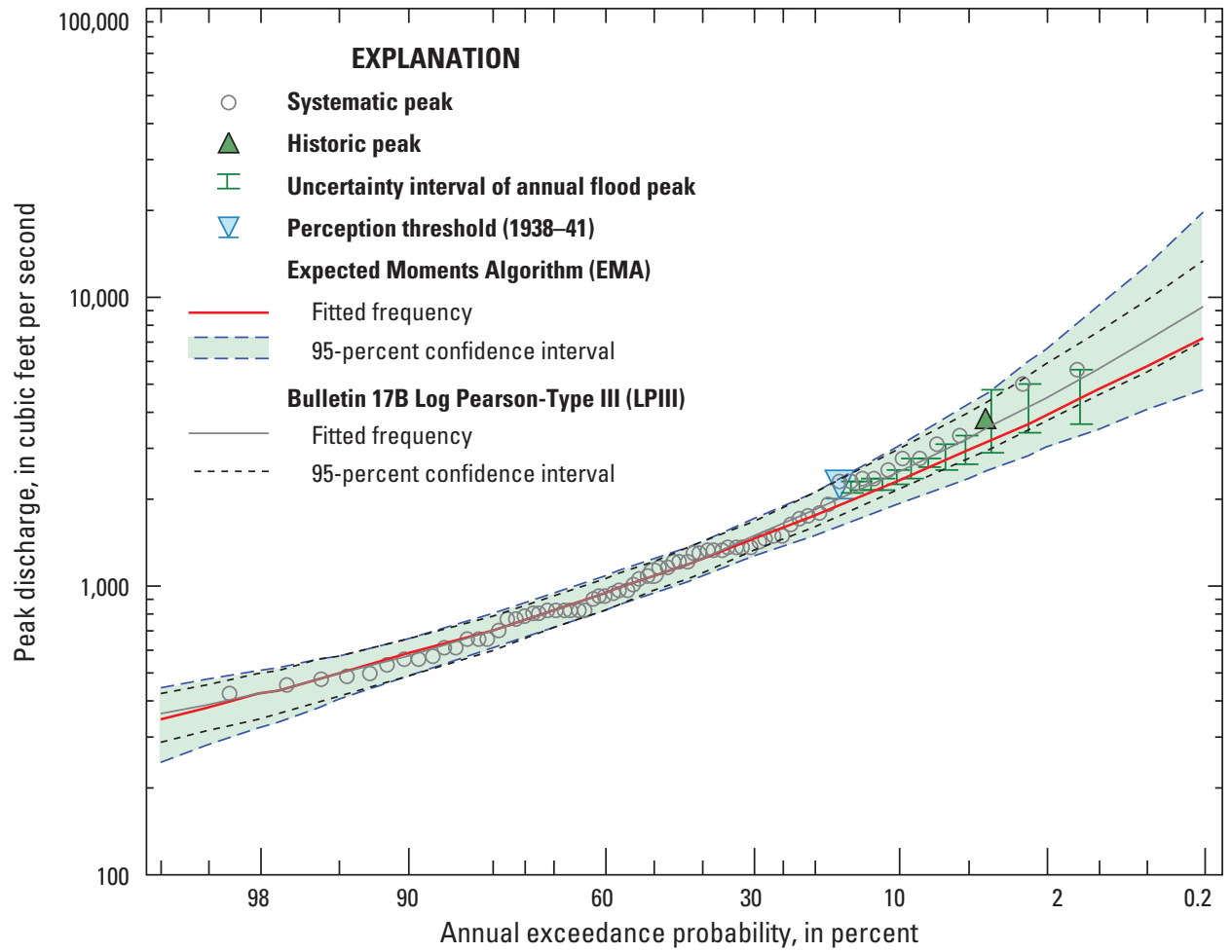

Figure 6. Uncertainty of $A$, annual peak and historic flows used to compute $B$, flood frequency curve at Mount Hope River near Warrenville, CT (01121000). The perception threshold, assigned to the period between the historic peak (1938) and the start of the systematic record (1941), informs the EMA analysis that peak flows during this period did not exceed that threshold. Bulletin 17B is Interagency Committee on Water Data (1981). 
Table 6. Annual exceedance probability, flood quantiles, and confidence limits for Mount Hope River near Warrenville, CT (01121000).

[Values are in cubic feet per second except for percent difference. CT, Connecticut; AEP, annual exceedance probability; B17B, Bulletin 17B (Interagency Committee on Water Data, 1981); EMA, expected moments algorithm; \%, percent]

\begin{tabular}{|c|c|c|c|c|c|c|c|c|c|}
\hline \multirow{3}{*}{$\begin{array}{c}\text { AEP } \\
\text { (percent) }\end{array}$} & \multicolumn{3}{|c|}{ B17B } & \multicolumn{3}{|c|}{ EMA } & \multirow{2}{*}{\multicolumn{3}{|c|}{ Percent difference }} \\
\hline & \multirow{2}{*}{ Estimate } & \multicolumn{2}{|c|}{$95 \%$ confidence } & \multirow{2}{*}{ Estimate } & \multicolumn{2}{|c|}{$95 \%$ confidence } & & & \\
\hline & & Lower & Upper & & Lower & Upper & Estimate & Lower & Upper \\
\hline 4 & 3,360 & 2,830 & 4,170 & 3,120 & 2,500 & 4,670 & -7.1 & -12 & 12 \\
\hline 2 & 4,270 & 3,510 & 5,480 & 3,860 & 2,970 & 6,550 & -9.6 & -15 & 20 \\
\hline 0.5 & 6,640 & 5,210 & 9,100 & 5,670 & 4,000 & 12,800 & -15 & -23 & 41 \\
\hline 0.2 & 8,720 & 6,640 & 12,400 & 7,160 & 4,750 & 19,700 & -18 & -28 & 59 \\
\hline
\end{tabular}

\section{Annual Exceedance Probability Flood Estimates}

The magnitudes of flood flows were computed at 43 streamgages in Rhode Island (20 sites), Connecticut (14 sites), and Massachusetts (9 sites) using B17B as implemented in PeakFQ (Flynn and others, 2006). At-site flood magnitudes also were computed by the EMA analysis (Cohn and others, 1997, 2001; Griffs and others, 2004) as implemented in PeakFQ version 6.0.14667 and in PeakfqSA (Tim Cohn, U.S. Geological Survey, written commun., March 9, 2011). All at-site analyses were determined using a weighted regional skew of 0.52 and RMSE of 0.46, except for Pawtuxet River at Cranston, RI (01116500), where only the at-site skew was used because of upstream regulation from a supply reservoir.

Results (table 7, in back of report) are presented for 20-, 10-, 4-, 2-, 1-, 0.5-, and 0.2-percent AEPs, which are also referred to as 5-, 10-, 25-, 50-, 100-, 200-, and 500-year floods. The results include a B17B analysis for the streamgage period of record and for extended record were applicable, except for Chepachet River at Chepachet, RI (01111400), which only has 11 years of record and, therefore, only the extended record analysis is presented. For comparison purposes, the table also provides the flood flows computed from the systematic record, which are based on the station skew and do not account for low outlier or historic data adjustments.

Values listed in bold in table 7 (in back of report) are the values used to develop the regionalized flood flow regression equations. In general, values used in the regional regression were computed by $\mathrm{B} 17 \mathrm{~B}$ for the period of record if the record was not extended. If the record was extended, then the B17B extended record analysis values were used in the regional regression. If the uncertainties incorporated into the EMA were appreciable, then the EMA computed values were used; if the uncertainties are not appreciable or no uncertainties were incorporated into the analysis, then the EMA values are the same (or nearly so given rounding differences) to the B17B analysis for the same period of record. The EMA uncertainty estimates are summarized in the footnote for each streamgage where applicable.

Flood magnitude results are provided for Wood River near Arcadia, RI (01117800), but the streamgage was not used in the development of the regional flood flow equations. This long-term streamgage has 47 years of record, but the annual peak flows are highly correlated to the annual peaks at the downstream gage at Hope Valley (01118000) and therefore considered redundant. Pawtuxet River at Cranston, RI (01116500) also was not used in the regional regression because of upstream regulation.

\section{Uncertainty of Estimates}

Many factors affect the confidence interval surrounding estimates of the flood magnitude for a given AEP. Foremost is the extent to which the sample population (annual peak flows) represents the true population of flood magnitudes. Bulletin $17 \mathrm{~B}$ incorporates this uncertainty by the length of the record, and the mean and variability of the peak flows used in the analysis; the confidence level decreases, particularly at the tails of the distribution, as the record length decreases and the variability increases.

In addition to the improvements the EMA makes for quantifying uncertainty for the period of nonsystematic record and for specific peaks used in the analysis, the EMA also provides a more robust estimate of the overall uncertainty of the flood magnitude by a derived approximation of the variance of the EMA moments and flood quantile estimators (Cohn and others, 2001). In practice, annual peaks, particularly high outliers, are generally within the 95 -percent confidence level determined by the EMA but often are well outside the 95-percent confidence level determined by B17B. Hence, the confidence intervals for a given AEP are much broader for the EMA than for B17B, but are more realistic of the range of potential flows for a given AEP. 


\section{Magnitude of Flood Flows at Ungaged Streams}

Equations to estimate magnitude of floods at selected AEPs at ungaged sites were developed from flood magnitudes at selected streamgages described above and their respective basin characteristics. Basin characteristics are used to explain the variability of flow for a given AEP through regional regression techniques. Similar to the at site analysis, regression equations were developed for 20-, 10-, 4-, 2-, 1-, 0.5-, and 0.2 -percent AEP floods. The development of regional flood flow equations consist of three basic parts-(1) compilation of basin characteristics, (2) exploratory analysis of the characteristics and flood flows to evaluate the best explanatory variables and their transformations, and (3) use of robust regression methods to develop the final equations and uncertainty of the estimates.

\section{Basin Characteristics}

Basin characteristics are used to relate the magnitude of floods determined from the streamgage analyses to develop equations for estimating flood magnitudes at ungaged streams. A total of 55 basin and climate characteristics were compiled for the initial exploratory analysis of potential explanatory variables (appendix 1). These variables can be broadly characterized by land use type, terrain, infiltration, basin and stream morphology, and climate. The distribution of selected basin characteristics (fig. 7) for the 41 streamgages used in the analysis varied by state; generally, the characteristics overlap among states with differences reflecting the region characteristics shown in figures 1 and 2.

\section{Exploratory Analysis}

From the potential explanatory variables compiled, variables were evaluated for cross correlation and linearity. Variables that required transformation to achieve better linear relation are those that have a large range in values and are typically direct measures of a basin characteristic such as the drainage area (independent variable) and for flood flows (dependent variable). Most independent variables examined did not require transformation because they represent a characteristic that is normalized by the basin size or expressed in terms of a percentage, such as the percentage of basin that is impervious. Regardless of whether a transformation was needed, transformations were tested because of potential gains in the normality of the regression residuals. Exploratory statistics were made using TIBCO Spotfire S+ (version 8.1).

The ordinary least squares (OLS) method was used to identify explanatory variables that best describe the flood magnitudes for the selected AEPs using an automated subset selection from possible subsets of selected variables. Subsets of variables were made so that well correlated variables were not used simultaneously to avoid covariance that can adversely affect a regression. Variables within a subset are automatically tested individually and in various combinations to determine which variables or combinations of variables best explain the variability of the flood magnitudes for a given AEP among streamgages used in the analysis.

The explanatory variables that best describe the flood flows were selected on the basis of several factors, including the standard error (SE) of the estimate, Mallow's $C_{p}$ statistic, (3) adjusted $R^{2}$, residual sum of squares (PRESS) statistic, and the statistical significance of the explanatory variables. The OLS models with a smaller SE, Mallow's $C_{p}$, and PRESS values and higher adjusted $R^{2}$ values were identified. In addition, the explanatory variables were selected based on normality of the distributed error or residuals and for multicolinearity by the variance inflation factor (VIF). From this analysis, six variables were chosen for further analysis - drainage area (DA), stream density (STRDEN), storage (StorNHD), mean basin slope (MBSLP), impervious area (IMPERV), and area underlain by sand and gravel (SG). The ranges of values used in the analysis are listed in table 8 ; the values by streamgage are listed in appendix 1.

The variables in table 8 were further tested using weighted least squares (WLS) regression, which indicated that transforming all variable values to base 10 logarithms produced slightly better models than only transforming flow and drainage area needed to satisfy requirements for linearity. WLS also was used to test different weighting schemes based on the period of record that was adjusted on the basis the overall quality of the record, and the amount of extended record and its quality. In all cases, the period of actual record produced a slightly better model fit than the other weights tested.

\section{Regional Regression Equations}

The final regression equations were developed by the generalized least squares (GLS) method as implemented in the Weighted Multiple Linear Regression program (WREG) version 1.03 (Eng and others, 2009). GLS in WREG incorporates the evolution of the technique as developed and described over time by Stedinger and Tasker $(1985,1986)$, Tasker and Stedinger (1989), Martins and Stedinger (2002), and Griffis and Stedinger $(2007,2009)$. The advantage of GLS compared with OLS and WLS is that GLS accounts for differences in available record length (as does WLS), but also accounts for the spatial correlation of concurrent annual peak flows among streamgages used in the regression. The GLS procedure separates the total variance of the residuals by model error and sample error by an estimator of the sampling error covariance matrix for each flood quantile and the error associated with the weighted skew. Collectively, the enhanced features of a GLS regression provide the most robust model for regionalization of flood flows (Griffis and Stedinger, 2007).

The best explanatory variables determined from the OLS and WLS analyses (table 8) were tested in GLS using the 

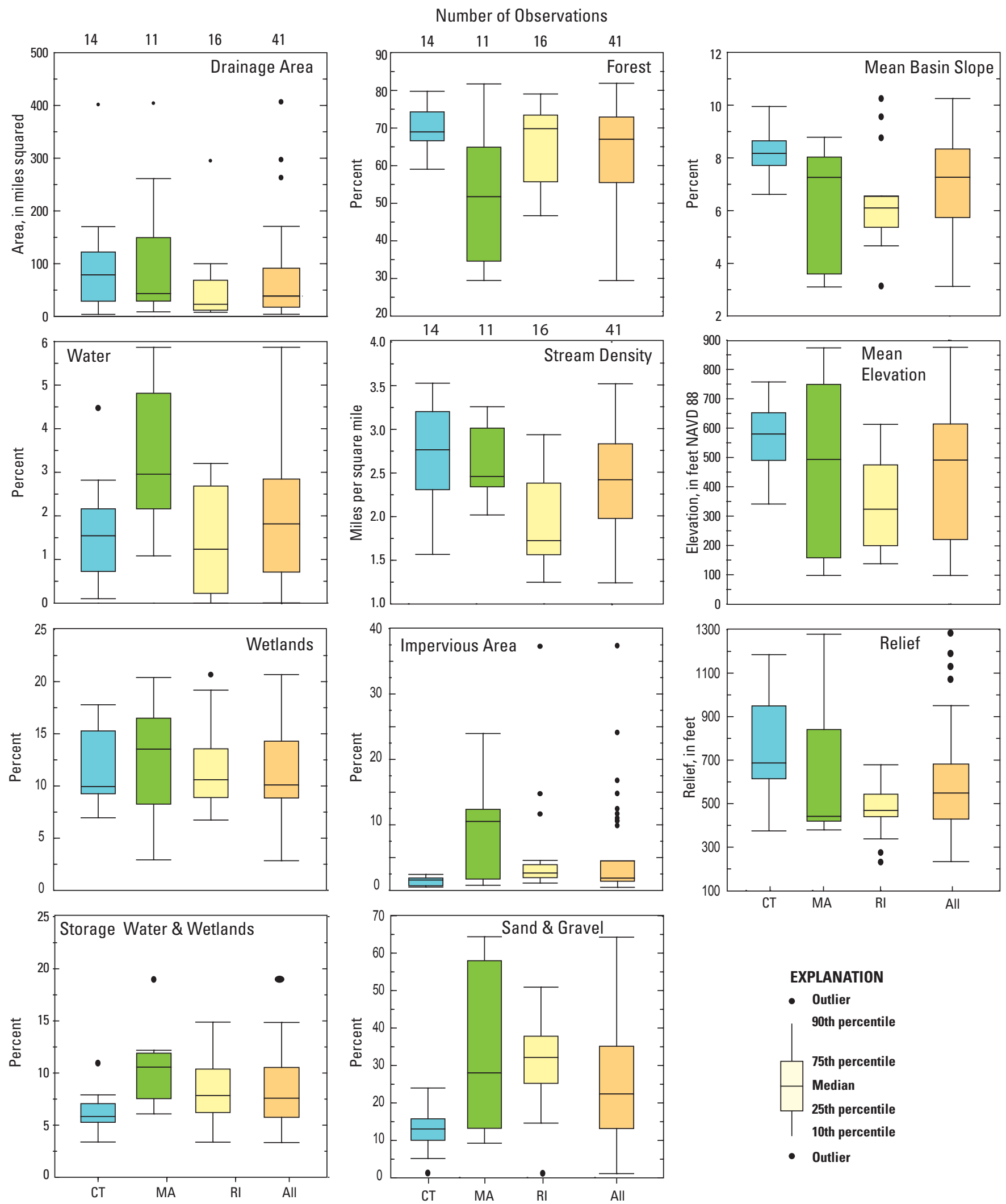

Figure 7. Selected streamgage basin characteristics in Rhode Island (RI), Connecticut (CT), and Massachusetts (MA) used in flood frequency analysis. 
Table 8. Ranges of the basin characteristic values used to develop regional flood flow regression equations.

\begin{tabular}{llccc}
\hline Basin characteristic & Name & Minimum & Mean & Maximum \\
\hline Drainage area, in square miles & DA & 4.00 & 80.2 & 404 \\
Stream density, in miles per square mile & STRDEN & 1.25 & 2.38 & 3.53 \\
Storage, in percentage of basin in open water and wetlands ${ }^{\mathrm{a}}$ & StorNHD & 3.37 & 8.08 & 19.0 \\
Mean basin slope, in percent & MBSlp & 3.11 & 6.92 & 10.2 \\
Impervious area, in percentage of basin area & IMPERV & 0.50 & 5.24 & 37.2 \\
Sand and gravel, in percentage of basin underlain & SG & 1.10 & 25.9 & 64.4 \\
\hline
\end{tabular}

${ }^{a}$ As defined in the National Hydrography Dataset (NHD).

period of actual systematic record to develop the covariance matrix and weights. The final analysis used $\log _{10}$ transformations for all variables. For all the AEPs flood quantiles DA, STRDEN, and StorNHD were statistically significant at the 95-percent confidence level. The MBslp was not significant at the 95-percent confidence level for flood flows at and below the 4-percent AEP but was increasingly statistically significant for floods at and above the 2-percent AEP. However, including the MBslp in the regional equation was determined to be marginally beneficial at the lower exceedance probabilities and was dropped from the final equations. IMPERV, which is a surrogate measure of urbanization, was not statistically significant at the 95-percent confidence level at any AEP, but its influence on flood flows is discussed in more detail in the section on "Urban Influence."

The final regional regression equations for the 20through 0.2-percent AEPs (5- to 500-year floods) are:

$Q_{20 \%}=10^{\left(2.124+0.870 \times \log _{10}(D A)+0.770 \times \log _{10}(\operatorname{STRDEN})-0.856 \times \log _{10}(\operatorname{StorNHD})\right)}$

$Q_{10 \%}=10^{\left(2.264+0.870 \times \log _{10}(D A)+0.790 \times \log _{10}(\operatorname{STRDEN})-0.893 \times \log _{10}(\operatorname{StorNHD})\right)}$

$Q_{4 \%}=10^{\left(2.428+0.862 \times \log _{10}(D A)+0.802 \times \log _{10}(\operatorname{STRDEN})-0.919 \times \log _{10}(\operatorname{StorNHD})\right)}$

$Q_{2 \%}=10^{\left(2.537+0.857 \times \log _{10}(D A)+0.801 \times \log _{10}(\operatorname{STRDEN})-0.940 \times \log _{10}(\operatorname{StorNHD})\right)}$

$Q_{1 \%}=10^{\left(2.623+0.852 \times \log _{10}(D A)+0.792 \times \log _{10}(\operatorname{STRDEN})-0.941 \times \log _{10}(\operatorname{StorNHD})\right)}$

$Q_{0.5 \%}=10^{\left(2.713+0.851 \times \log _{10}(D A)+0.816 \times \log _{10}(\operatorname{STRDEN})-0.975 \times \log _{10}(\operatorname{StorNHD})\right)}$

$Q_{0.2 \%}=10^{\left(2.815+0.850 \times \log _{10}(D A)+0.829 \times \log _{10}(\operatorname{STRDEN})-1.002 \times \log _{10}(\operatorname{StorNHD})\right)}$ where

$Q_{20 \%} \ldots Q_{0.2 \%} \quad$ are flow magnitudes for 20- to 0.2-percent AEP floods, in cubic feet per second;

$D A \quad$ is the drainage area of the basin, in square miles;

STRDEN is the basin stream density, in miles per square mile; and

StorNHD is the basin storage, in percent.

Note that $D A$ and $S T R D E N$ are positive coefficients, which means that, as $D A$ and $S T R D E N$ increase, so does the magnitude of flow. StorNHD has a negative coefficient, which means that, as StorNHD increases, flow decreases. This is a reflection of the effects of storage in mitigating flood flows.

Equal distribution of residuals, the difference between the simulated and observed, is an important consideration in the validity of a linear regression model. Boxplots show residuals are nearly equally distributed around zero for each of the AEP flood quantiles (fig. 8), indicating the regression models are unbiased. Furthermore, the residuals show no spatial pattern (fig. 9), but appear to be inversely related to the station skew (fig. 4). Streamgages with high skews tend to have low residuals, and streamgages with low skews tend to have high residuals. One possible explanation is that streamgages with high at-site skews will have a lower weighted skew, causing the flow magnitudes to decrease and the residual to increase. Conversely, streamgages with low at-site skews will have a higher weighted skew, causing the flow magnitudes to increase and the residual to decrease.

No streamgage appears to have undue leverage or influence in the regression. However, Pendleton Hill Brook near Clark Falls, CT (01118300) is among the streamgages with the greatest leverage and influence because it has the smallest drainage area $\left(4.0 \mathrm{mi}^{2}\right)$ used in the analysis, and drainage area is the strongest explanatory variable. This underscores the importance of the inclusion of small basins in future regional regression equations if the equations are going to be applied to small drainage basins. 


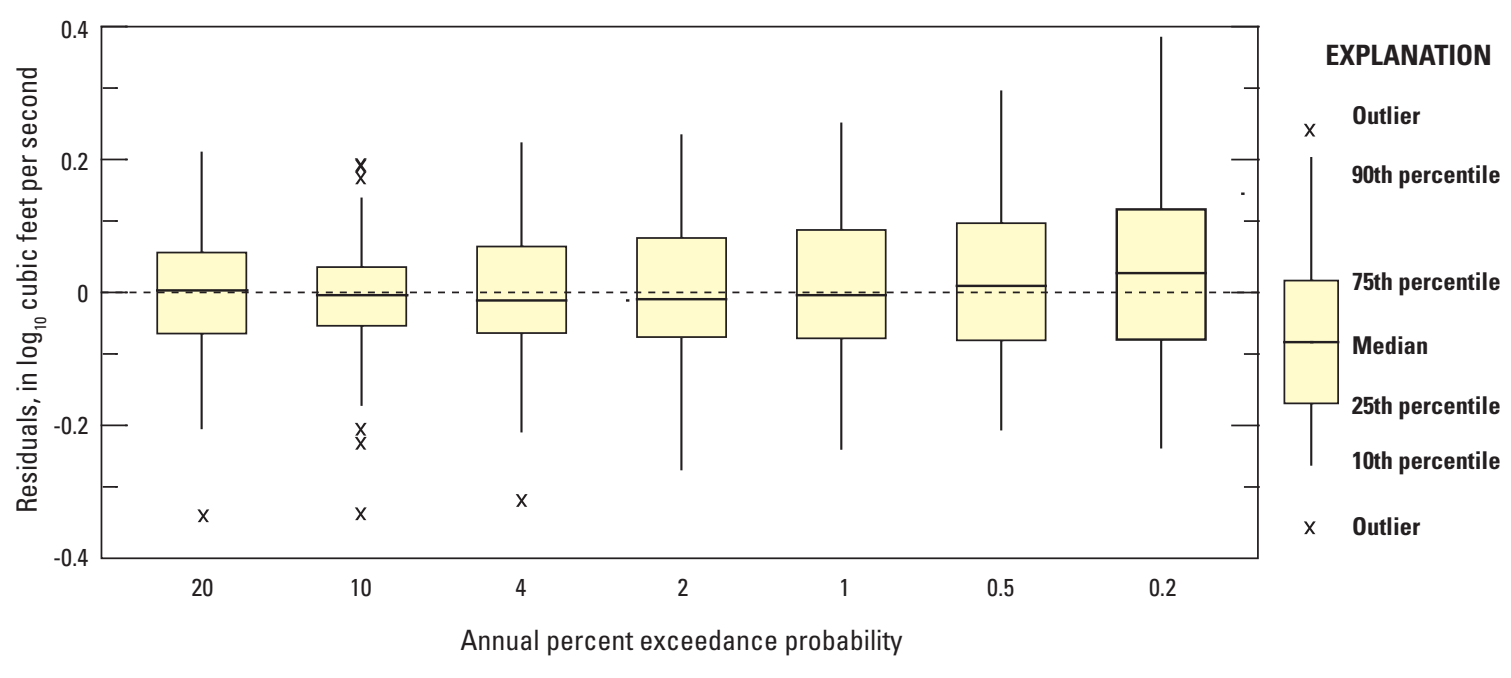

Figure 8. Residuals of generalized least squares (GLS) regional regression of floods for 20- to 0.2-percent annual exceedance probabilities at 41 selected streamgages in Rhode Island, Connecticut, and Massachusetts.

\section{Accuracy and Limitations}

Regression equations are statistical models developed from explanatory variables that best explain the variability of flood flows and are subject to the limitations of the data. These include the range of explanatory variables used in the analysis and the scatter or variance between the predicted and observed values. How well the predicted values represent the true values, or the accuracy of a regression, is an important consideration in the application of the model and the interpretation of the results.

The three parameter regionalized flood flow equations (2-8) best fit the computed at-site AEP flood flows (fig. 10A) without overfitting the data. At higher flows, the regionalized equations tend to undersimulate flood flows, but these values are from basins larger than $100 \mathrm{mi}^{2}$ outside of Rhode Island (fig. 10B). In addition, the Rhode Island regionalized flood flow equations are primarily needed for basins smaller than $100 \mathrm{mi}^{2}$ because the large basins in the state have long-term streamgages to can be used for flood analysis.

Several metrics of model fit are generated for the GLS analysis in WREG; these include the pseudo coefficient of determination (pseudo- $R^{2}$ ), the average standard error of prediction, and the standard model error. The pseudo- $R^{2}$ (Griffis and Stedinger, 2007) value is based on the variability in the dependent variable (flood flow) explained by the regression after removing the effect of time sampling error. The pseudo$R^{2}$ is similar to the standard regression coefficient of determination $\left(R^{2}\right)$ in that, the closer the value is to 1.0 , the better the model fit and the greater the amount of variance explained by the regression. Pseudo- $R^{2}$ ranged from 94 to 96 percent and was slightly lower at the higher and lower AEPs flood quantiles (table 9). The percent average standard error of prediction (table 9) is the percentage form of the mean of the variances of prediction calculated at each of the streamgages used in constructing the regression model (Tasker and Stedinger, 1986). The square root of the variance of prediction is the standard error of prediction. Both are measures in the spread or dispersion of the predicted value from the observed value; hence, the lower the values, the less the expected spread of predictions around the true (unknown) value. Details of how the average variance of prediction and average standard error of prediction are determined are given in appendix 2.

The equations produce estimates of flood flows for the select exceedance probabilities where human influences have little or no effect on the magnitude of floods. Rivers with large regulated impoundments for water supply or flood control, for example, would not be an appropriate use of these equations. Applicability of flood flow estimates determined from basin characteristics outside the range characteristics from which the equations were derived (table 8) is unknown. 


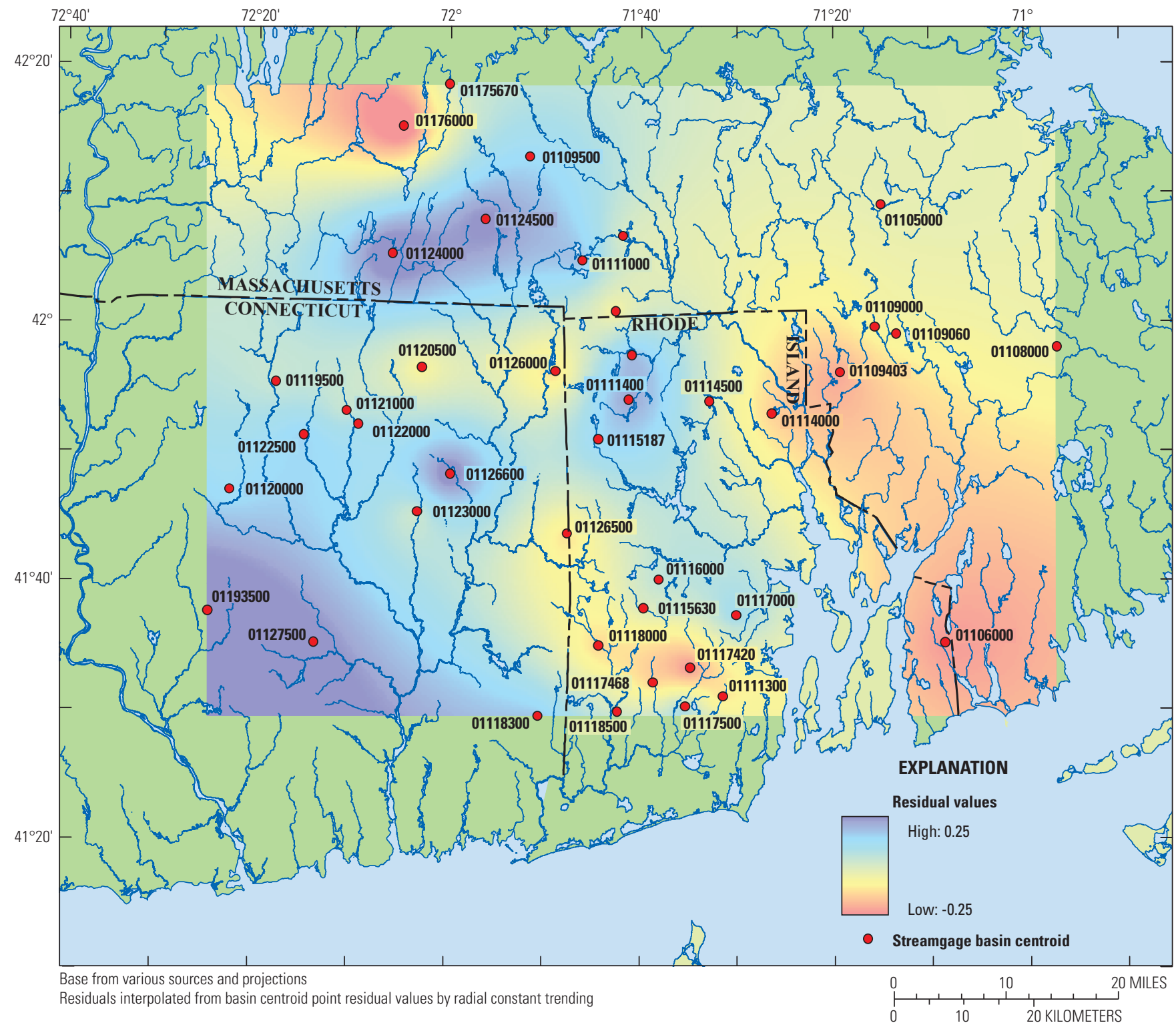

Figure 9. Residuals of generalized least squares (GLS) regional regression and at-site 1-percent annual exceedance probability flood flows at 41 selected streamgages in Rhode Island, Connecticut, and Massachusetts. 

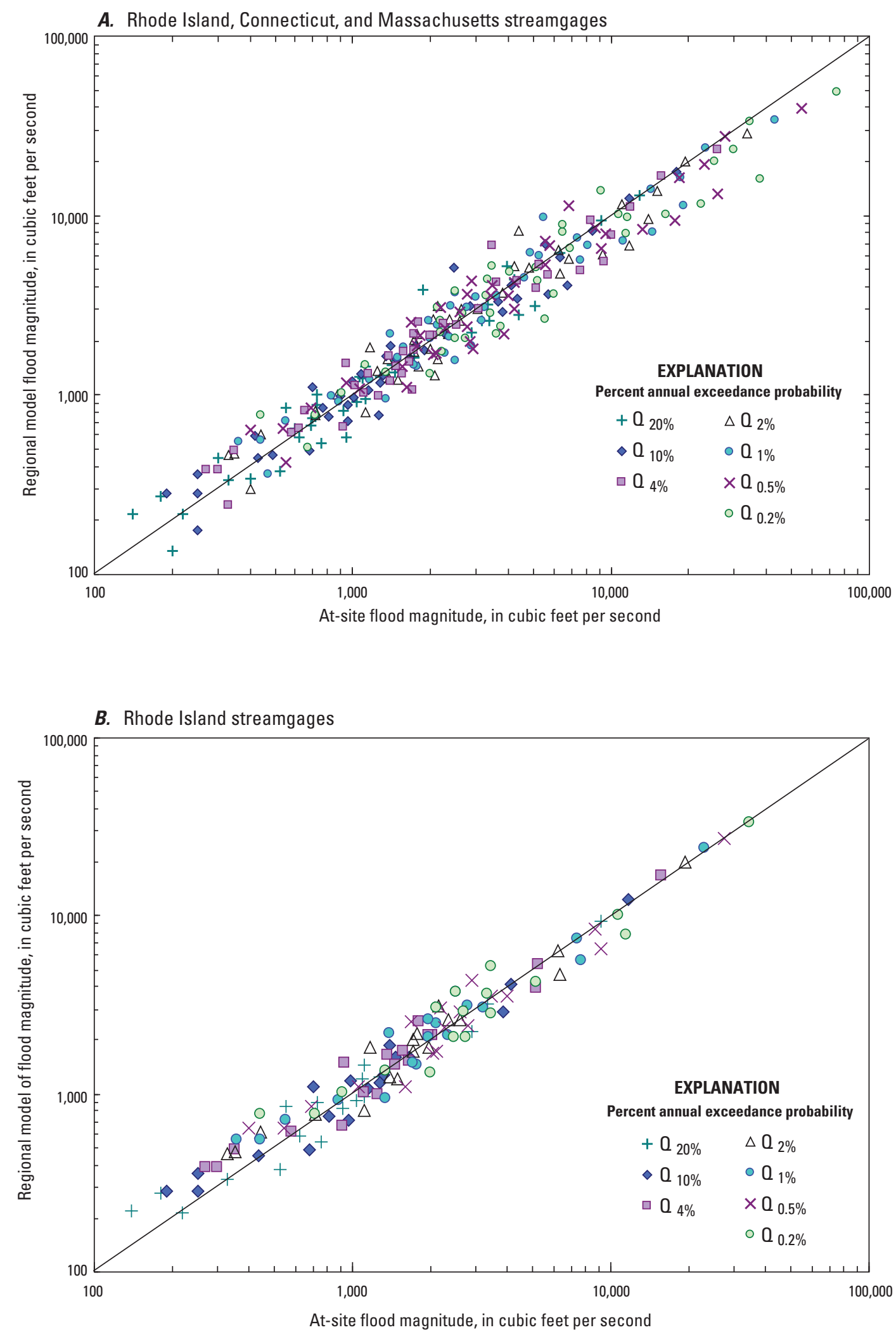

Figure 10. Flood magnitudes for selected annual exceedance probabilities determined from at-site analyses and from regional flood flow equations at $A, 41$ streamgages in Rhode Island, Connecticut, and Massachusetts, and $B, 18$ streamgages in Rhode Island. 
Table 9. Pseudo-coefficient of determination (pseudo- $R^{2}$ ), average variance of prediction, and standard error of prediction for the regional flood flow regression equations.

\begin{tabular}{cccc}
\hline $\begin{array}{c}\text { Annual } \\
\text { exceedance } \\
\text { probability } \\
\text { (percent) }\end{array}$ & $\begin{array}{c}\text { Pseudo- } \boldsymbol{R}^{2} \\
\text { (percent) }\end{array}$ & $\begin{array}{c}\text { Average } \\
\text { variance } \\
\text { of prediction } \\
\text { (percent) }\end{array}$ & $\begin{array}{c}\text { Average } \\
\text { standard error of } \\
\text { prediction } \\
\text { (percent) }\end{array}$ \\
\hline 20 & 96 & 27.2 & 25.1 \\
10 & 95 & 25.9 & 23.4 \\
4 & 96 & 24.0 & 20.9 \\
2 & 96 & 24.5 & 21.1 \\
1 & 96 & 24.2 & 20.6 \\
0.5 & 96 & 26.6 & 22.3 \\
0.2 & 95 & 29.6 & 24.8 \\
\hline
\end{tabular}

\section{Uncertainty Estimates of Regionalized Equations}

The uncertainty of a regression equation is indicated by the confidence interval. A confidence interval is the spread between the minimum and maximum values within which there is a stated probability that the true value of the response variable can exist. As an example, the minimum and maximum values at the 95-percent confidence level for the 1-percent AEP flood for an ungaged site means there is 95-percent confidence that the true value of the 1-percent AEP flood is within the stated intervals.

Driver and Tasker (1990) have shown that a 100(1- $\alpha)$ confidence interval for the true value of a streamflow statistic obtained for an ungaged site from a regression equation can be computed by:

$$
\frac{Q}{C}<Q<Q \times C
$$

where

$Q \quad$ is the flood magnitude for the ungaged site, in cubic feet per second; and

$C$ is the confidence interval computed as:

$$
C=10^{T * S p, i},
$$

where

$T \quad$ Student $t$ value from statistic table for a given confidence level and degrees of freedom (for a 95-percent level $\alpha=0.05$ and degrees of freedom is equal to number of observations minus the number of variables, $42-4=38 ; T=2.024)$; and

$S p, i \quad$ is standard error of prediction for site $i$.

The value of $S p, i$ is computed using the equation:

$$
S p, i=\left[\gamma^{2}+x_{i} U x_{i}^{\prime}\right]^{0.5}
$$

where

$$
\begin{aligned}
& \gamma^{2} \text { model error variance, } \\
& x_{i} \quad \text { a row vector of the logarithms of the } \\
& \text { explanatory variables }(D A, S T R D E N \text {, and } \\
& \text { StorNHD) for site } i \text {, augmented by a } 1 \text { as } \\
& \text { the first element; } \\
& U \text { covariance matrix for the regression } \\
& \text { coefficients; and } \\
& x_{i}^{\prime} \quad \text { transpose of } x_{i} \text { (Ludwig and Tasker, 1993). }
\end{aligned}
$$

An example calculation of the 95-percent confidence interval is given for a hypothetical ungaged stream site with the following characteristics-DA of $30 \mathrm{mi}^{2}$, STRDEN of $3.53\left(\mathrm{mi} / \mathrm{mi}^{2}\right)$, and StorNHD of 6.77 percent. The $x_{i}$ vector computed from the explanatory basin characteristics is

$$
x_{i}=\left\{1, \log _{10}(30.0), \log _{10}(3.53), \log _{10}(6.77)\right\} \text {. }
$$

The model error variance $\left(\gamma^{2}\right)$ and the covariance matrix $(U)$ were determined from the WREG GLS analysis and are reported in table 10. For a 1-percent AEP flood (100-year flood) the procedure for computing the 95 -percent confidence interval is as follows:

- compute $S p, i$ using equation 11:

$$
S p, i=(0.00908+0.00361)^{0.5}=0.11264 ;
$$

converted from $\log _{10}$ units

- compute $C$ using equation 10 :

$$
C=10^{(2.024 \times 0.11264)}=1.69037
$$

- compute the 1-percent AEP flood from equation 6:

$$
Q_{1 \%}=3,590 \mathrm{ft}^{3} / \mathrm{s}
$$

- compute the 95-percent confidence interval from equation 9:

$$
\frac{3,590}{1.69037}<Q_{1 \%}<3,950 \times 1.69037,
$$

- or

$$
2,110 \mathrm{ft}^{3} / \mathrm{s}<3,590 \mathrm{ft}^{3} / \mathrm{s}<6,070 \mathrm{ft}^{3} / \mathrm{s} .
$$

A spreadsheet for solving the regional regression equations at ungaged sites from user specified explanatory values for flood magnitudes with a 20-, 10-, 4-, 2-, 1-, 0.5-, and 0.2-percent AEPs and the 95-percent confidence interval can be accessed through a hyperlink in appendix 3 . The graphical results from the hypothetical test basin computed from the spreadsheet are shown in figure 11. 
Table 10. Model error variance and covariance values needed to determine the uncertainty of the regional regression equations.

$\left[\gamma^{2}\right.$, the regression model error variance in equation $11 ; U$, the covariance matrix in equation 11; The matrix horizontal and vertical variables are defined by the constant and the independent variables in equations $2-8$ in the order they are given]

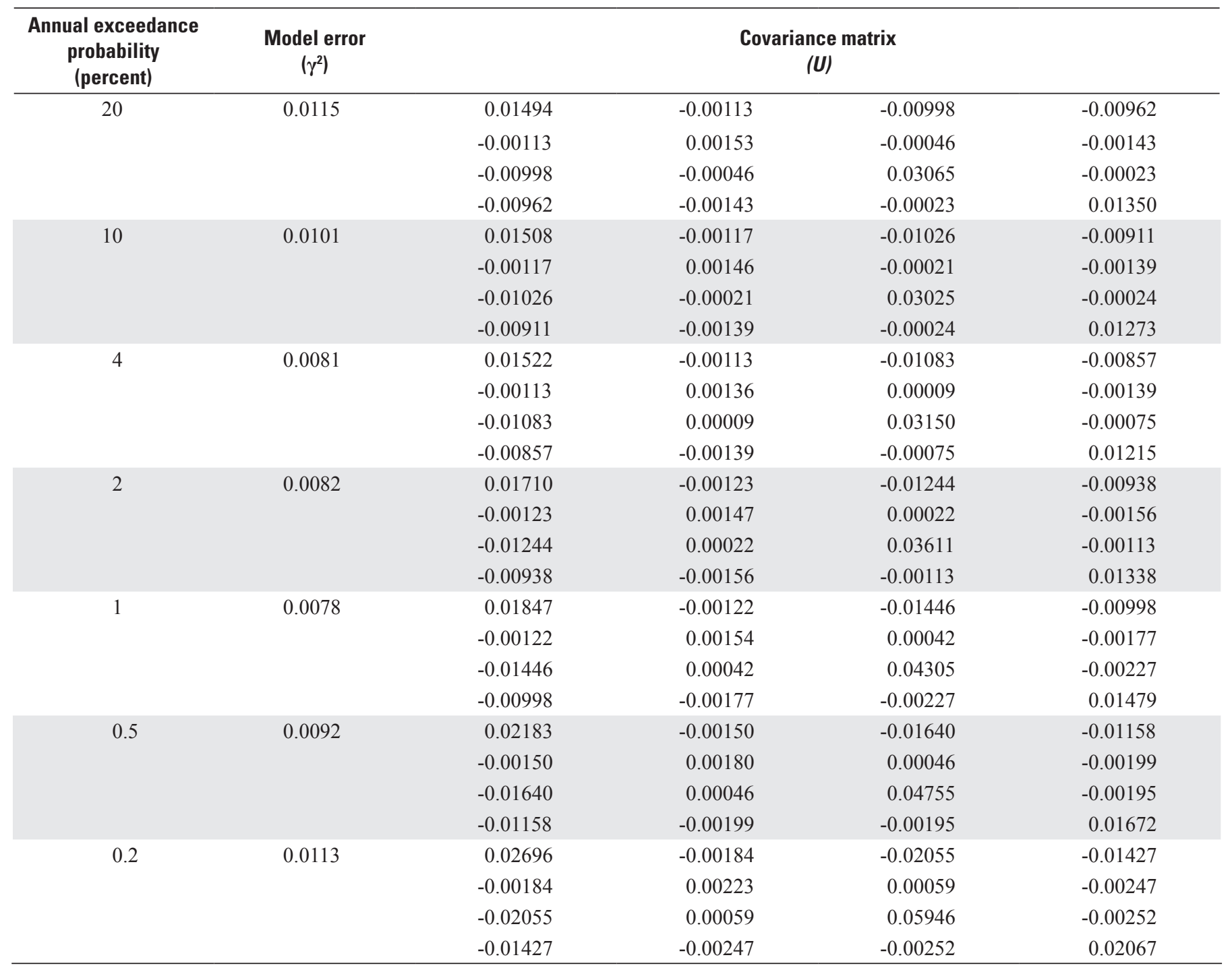

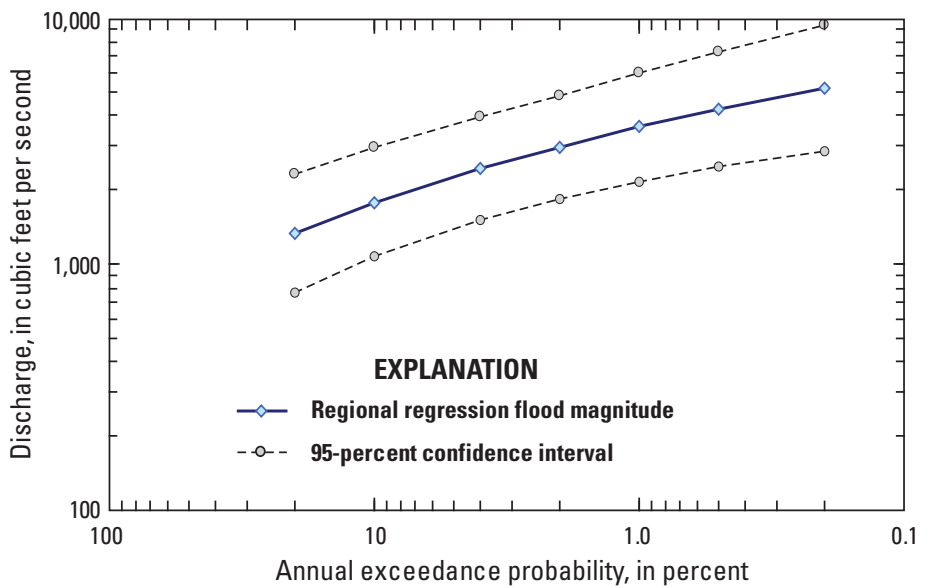

Figure 11. Regional regression estimates of the flood flows and confidence intervals for a hypothetical basin. The hypothetical basin has a drainage area $(D A)$ of 30 square miles, a stream density (STRDEN) of 3.53 miles per square mile, and storage (StorHDN) of 6.77 percent. 


\section{Factors Affecting Flood Flow Estimates}

Many factors affect the magnitude of flood flows, some of which are incorporated into the regional regression equations by the most significant explanatory variables. Two important factors not included in the regional regression that can affect estimates of the magnitude of floods are the extent of urbanization and trends in the annual peak flows. Urbanization can restrict infiltration of precipitation and alter drainage patterns to move water away from developed areas. To the extent that the streamgages used in the analysis reflect different degrees of urbanization, and if the effects of urbanization are reasonably stable over the streamgage record, the at-site analysis includes these effects in the computed flood magnitudes. Hence, regional regression equations developed reflect the effects of urbanization over the range of urban gradients of the streamgages used. The basic question is how representative the streamgages used in the analysis are to other urbanized basins where flood flow regression equations are applied. Trends in annual peak flows affect the fundamental statistical basis for flood frequency analysis as currently performed, which is based on the assumption of stationarity. Trends can affect both the at-site analyses of flood flows and the regression equations on which they are based.

\section{Urban Influence}

Urban drainage basins contain appreciable amounts of impervious surface, such as roads and rooftops, which restrict infiltration of precipitation into the soil and alter drainage systems to move water away from developed areas through storm water drainage systems and channelized streams. These changes can result in increased storm runoff and can alter the timing of runoff in a way that increases the magnitude of the peak streamflow for a given amount of precipitation. The effects of imperviousness have been found to be more pronounced for small, more frequent storms than large infrequent storms (Hollis, 1975; Konrad, 2003). The reason for this is that, during large storms, soils become saturated, preventing further infiltration; this causes surface runoff to increase similar to the effect an impervious surface has for any size storm. Nevertheless, urban adjustments to regionalized flood flow equations for rural basins have been made to include some measure of urbanization, such as impervious surface (Southard, 2010), population density (Watson and Schopp, 2009), or composite urban indices, such as the basin development factor, which accounts for impervious surface as well as storm sewers, culverts, and stream channel alterations (Sauer and others, 1983; Sherwood, 1994).

The suite of basin characteristics tested in the development of regional flood flow equations for Rhode Island includes the percentage of the basin that is covered by impervious area (IMPERV). IMPERV was considered an important factor because of the long history of development in this region and the recognition that most basins of interest with respect to flooding are urbanized to some extent. IMPERV in the basins used in the regionalization analysis ranged from 0.5 to 37 percent with a mean of 5.2 percent (table 8), but the inter-quartile range among all basins was between 1.4 and 4.6 percent, which limits the extent that to which urbanization can be addressed from the available data.

As previously mentioned, IMPERV was not a statistically significant explanatory variable at the 95-percent confidence level for any of the exceedance probabilities examined. Despite this lack of significance in this analysis, other studies (Robbins and Pope, 1996; Southard, 2010; Gotvald and Knaak, 2011) found that imperviousness is an important predictor of the magnitude of flood flows. The exploratory statistical analysis done in this study indicated that IMPERV provided some explanatory power, generally ranking fifth or sixth among the variables examined.

The relation of IMPERV to the magnitude of the AEP flood quantile was further examined and was found to be complicated by other basin characteristics that can offset the effects of urbanization. Most notable was no relation was found between the magnitude of the 20-percent AEP flow and imperviousness for all basins (fig. 12A) but when the basins are stratified by surficial geology type, basins underlain by more than 40 percent sand and gravel show an increasing relation between the magnitude of the 20-percent AEP flow and imperviousness (fig. 12B). Areas with higher percentages of sand and gravel generally allow for greater storm water infiltration; thus, when the infiltration capacity is reduced by imperviousness, the effects on peak flows become more apparent than in areas with naturally lower infiltration. Sand and gravel deposits also tend to be in valley fill areas in the lower parts of the basin where urban areas tend to be more concentrated. Where urban areas are concentrated in the lower basin the effects on peak runoff are less pronounced because the enhanced drainage from the urban areas accelerates the peak relative to the peak from the upper parts of the basin that can reduce overall peak flow from the basin. This interplay between variables complicates the effects of urbanization and its significance in regional analyses.

The relative increase in the annual maximum discharge in urbanized basins has been shown to be more substantial for small frequent floods than for large infrequent floods (Hollis, 1975; Konrad and Booth, 2002; Konrad, 2003). A similar relation can be seen at three long-term streamgages in Moshassuck River at Providence, RI (01114000), Woonasquatucket River at Centerdale, RI (01114500), and Wood River near Arcadia, RI (01117800). All three sites generally have similar dominant explanatory basin characteristics (table 11) except for the percentage of impervious area (about 37, 12, and 0.8 percent, respectively). The dominant explanatory basin characteristics at these sites ranged between 23.1 to $38.3 \mathrm{mi}^{2}$ for DA, 1.35 to $2.46 \mathrm{mi} / \mathrm{mi}^{2}$ for STRDEN, and 4 to 11 percent for StorNHD. The mean basin slope (6 to 10 percent) and percentage of area underlain by sand and gravel ( 22 to 28 percent) are also similar among basins. The basins are also in close proximity to each other; 

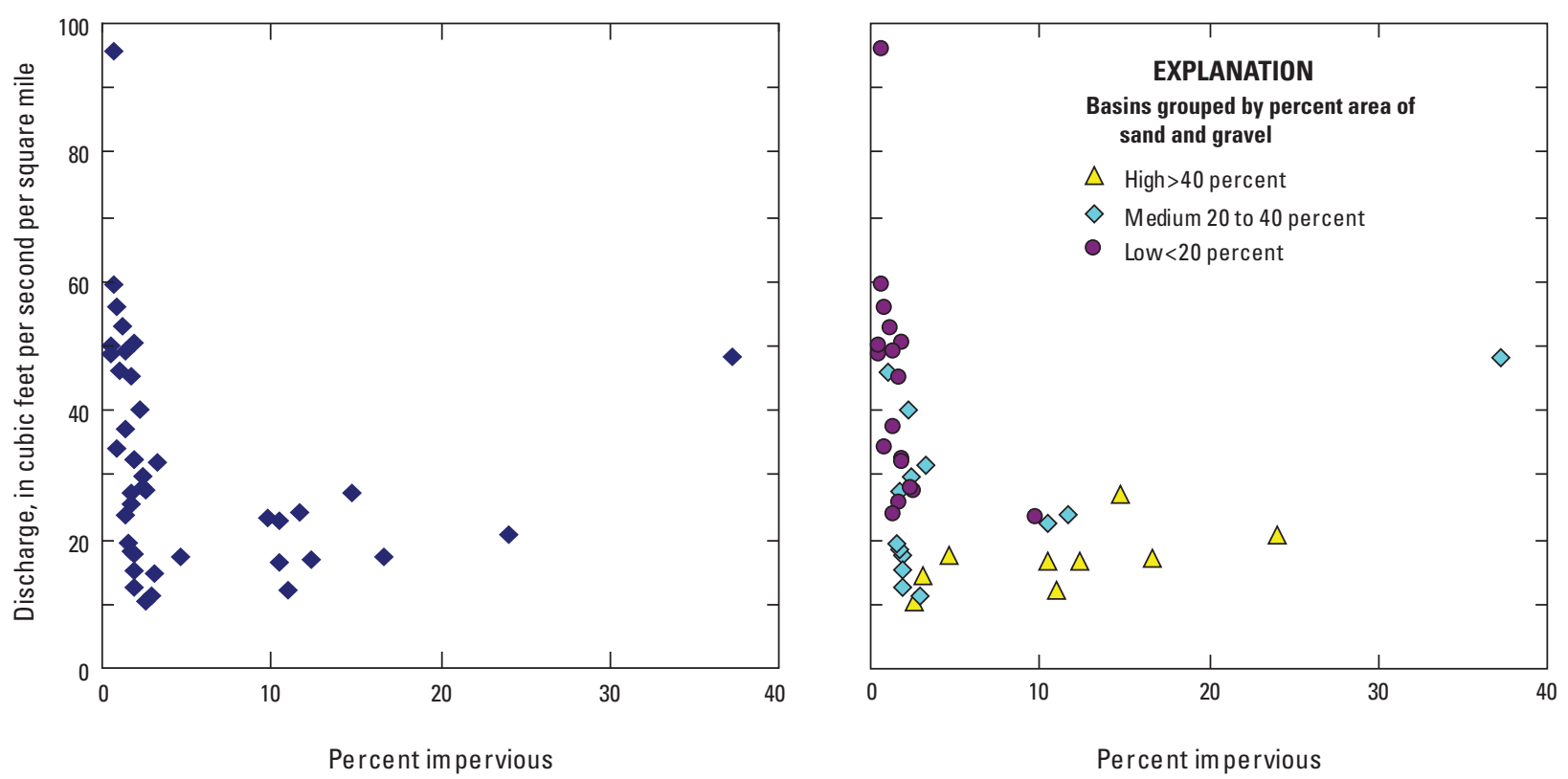

Figure 12. Relation of the magnitude of the 20-percent annual exceedance probability flood determined by regionalized equation to impervious area for $A$, all basins and $B$, basins grouped by ranges of the basin underlain by sand and gravel.

the Moshassuck River and the Woonasquatucket River Basins share a common divide, and the Wood River Basin is about 24 miles to the southwest of the other basins. Recent urban development in these basins has been mostly redevelopment of old development that dates back to the early industrial revolution (1800s) in the United States. Thus, the period of common streamflow record from these basins that starts in 1964 is largely unaffected by new urban growth.

The 47-year common streamflow record and similar basin characteristics among these basins, other than the extent of imperviousness, provides an opportunity to compare the effects of urbanization. The at-site analysis as described previously was performed for each of these streamgages using a common period of record (1964-2010). The AEP flood quantiles were normalized for drainage area for comparison. Flood magnitudes increased as the percent impervious area increased for high AEP flows (smaller more frequent floods). However, when expressed as a ratio of the flood magnitude of the more urbanized basin to the less urbanized basin, the differences between basins becomes less clear (fig. 13). In all cases, the ratio decreases as the AEP decreases; that is, the effects of urbanization decrease for larger less frequent floods. The ratio of the Woonasquatucket River to the Wood River is near one at the 1-percent AEP flood flow and becomes less than one for less frequent floods. Further, the relative difference in the normalized flood magnitude between the two most urbanized basins (Moshassuck and the Woonasquatucket River) and the least urbanized basin (Wood River) decrease more as the AEP decreases relative to the differences between the two more urbanized basins. The most prominent decrease in the ratio

Table 11. Characteristics of three basins used to compare effects of urbanization.

[DA, drainage area; $\mathrm{mi}^{2}$, square mile; Elev, elevation in North American Vertical Datum of 1988; STRDEN, stream density; mi², square miles; mi/mi², miles per square mile; IMPERV, imperviousness; StorNHD, storage; S\&G, sand and gravel]

\begin{tabular}{|c|c|c|c|c|c|c|c|c|c|}
\hline \multirow{2}{*}{ Number } & \multirow{2}{*}{ River } & \multirow{2}{*}{$\begin{array}{c}\text { DA } \\
\left(\mathrm{mi}^{2}\right)\end{array}$} & \multirow{2}{*}{$\begin{array}{c}\text { Elev } \\
\text { (feet) }\end{array}$} & \multirow{2}{*}{$\begin{array}{l}\text { STRDEN } \\
\left(\mathrm{mi} / \mathrm{mi}^{2}\right)\end{array}$} & \multicolumn{5}{|c|}{ Percent } \\
\hline & & & & & Slope & Forest & IMPERV & StorNHD & S\&G \\
\hline 01114000 & Moshassuck & 23.1 & 202 & 1.75 & 6.2 & 53 & 37.2 & 3.9 & 28.4 \\
\hline 01117800 & Wood & 35.2 & 390 & 1.35 & 6.9 & 71 & 0.83 & 7.8 & 27.1 \\
\hline
\end{tabular}




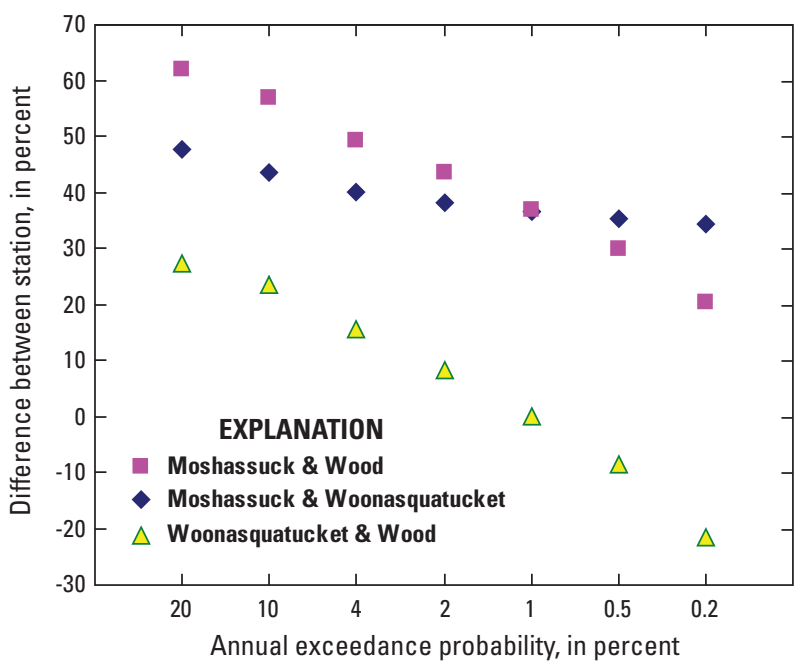

Figure 13. Ratio of flood magnitudes for select annual exceedance probabilities normalized by drainage area between streamgages with different extents of basin urbanization. The at-site analysis was computed from annual peak records from 1964-2010 for the Moshassuck River at Providence, RI (01114000), Woonasquatucket River at Centerdale, RI, (01114500), and Wood River near Arcadia, RI (01117800).

as the AEP decreases was between the most urbanized basin (Moshassuck) and the least urbanized basin (Wood River) from about 2.6 to 1.3 for 20- to 0.2-percent AEP flood flows, respectively. The least amount of change was between the two most urbanized basins - from about 1.5 to 1.9 for 20 - to 0.2-percent AEP flood flows, respectively. The reason for these relative differences is not clear, but underscores some of the differences discussed previously and below.

Adjustments to regional rural flood flow equations to account for the influence of urbanization on flood magnitudes have been developed by Sauer and others (1983) for the United States. The rural equations were modified by Sauer and others to adjust for urbanization by including channel slope, basin storage, rainfall, impervious surface, and the basin development factor (BDF). The BDF is an index that accounts for alterations to the stream channel, sewering, and the extent of curbed streets, which often requires extensive field investigation to determine. Sauer and others showed that the urban to rural peak discharge ratio increases as impervious surface and BDF increase and decreases as the return period of the storm increases. For the 2-year storm, the ratio ranged from 1.3 in areas with low percent impervious and low BDF to 3.6 in basins with high impervious surface and a high BDF. For the 100 -year storm, the ratio of urban to rural flood flow ranged from 1.1 in areas of low impervious and low BDF to 2.4 in basins with high impervious and high BDF.

A more recent urban adjustment to rural flood flow equations was developed by Moglen and Shivers (2006) using either imperviousness or population density. The principal advantage of this method compared with the method developed by Sauer and others (1983) is that the explanatory variables can be readily obtained from available geographic information. However, the Moglen and Shivers method requires a different, time consuming process that involves adjusting annual peak flows over time to solve for coefficients that minimize an objective function in a nonlinear regression model. This analysis was not performed, but the calibrated coefficients for simple impervious models determined by Moglen and Shivers (2006) from 78 streamgages with 30 years record from several areas of the country are based on the following equations:

$$
U Q_{20 \%}=2.866 \times R Q_{20 \%}^{0.862}(I A+1)^{0.147}
$$

$$
U Q_{10 \%}=2.827 \times R Q_{10 \%}^{0.866}(I A+1)^{0.128}
$$

$$
U Q_{4 \%}=2.965 \times R Q_{4 \%}^{0.870}(I A+1)^{0.102}
$$

$$
U Q_{2 \%}=3.080 \times R Q_{2 \%}^{0.873}(I A+1)^{0.0825}
$$

$$
\begin{gathered}
U Q_{1 \%}=3.206 \times R Q_{1 \%}^{0.876}(I A+1)^{0.0628} \\
U Q_{0.2 \%}=3.541 \times R Q_{0.2 \%}^{0.883}(I A+1)^{0.0166}
\end{gathered}
$$

where

$$
\begin{array}{cc}
U Q_{p \%} & \begin{array}{c}
\text { discharge adjusted for urbanization, in cubic } \\
\text { feet per second, for p-percent AEP; }
\end{array} \\
R Q_{p \%} & \begin{array}{c}
\text { rural discharge estimate, in cubic feet per } \\
\text { second, for p-percent AEP; and }
\end{array} \\
I A & \text { impervious area, in percent. }
\end{array}
$$

The calibrated equations (12-17) indicate that imperviousness becomes less influential as the AEP decreases. That is, imperviousness is more important for floods that occur more frequently than for floods that occur less frequently. Equations 12-17 could be used to adjust the equations (2-8) developed in this study for urbanization, but further work is needed to determine the applicability of the coefficients.

Separate equations or adjustments to rural equations have been developed for urban and rural areas in other geographic regions. Adjustments to rural regression equations were made using methods similar to Sauer for North Carolina from the percent impervious cover (Robbins and Pope, 1996) and Jefferson County, Kentucky, by the BDF (Martin and others, 1997). Urban flood flow equations have been developed explicitly for Alabama (Hedgecock and Lee, 2010), Georgia (Gotvald and Knaak, 2011), and Missouri (Southard, 
2010) from either the BDF (Alabama) or the percentage of impervious surface (Georgia and Missouri), in addition to other basin characteristics. The ratios of urban to rural flood flows for 20- and 1-percent AEP were computed from the Alabama, Georgia, Kentucky, Missouri, and North Carolina studies. The median ratios of urban to rural flood flows were 1.4 for the 20-percent AEP and 1.2 for the 1-percent AEP, but in some cases (Missouri in particular), the ratio drops below 1.0 (fig. 14). This further underscores the complex effects of urbanization and the interaction other basin characteristics can have on peak runoff.

Although the effects of urbanization were shown to have a relative decrease with the decreasing flood AEP in this and other studies, the analysis in this study also indicates that the flood magnitude linearly increases in relation to increasing imperviousness in some basins with otherwise similar properties. However, there were insufficient data to develop a statistically significant relation, and further research is needed in this area, particularly for small, highly developed basins, to better assess the effects of urbanization on flood flows. The regionalized equations developed in this study appear to apply reasonably well to basins with less than 37 percent impervious area with drainage areas greater than $10 \mathrm{mi}^{2}$, but the applicability of the regional flood flow equations (2-8) in small urbanized basins is unknown.

\section{Trends in Annual Peak Flows}

Standard methods for calculating the magnitude of floods for a given exceedance probability are based on the assumption of stationarity, that is, the annual peak flows exhibit no significant trend over time. Milly and others (2008) called this assumption into question and advocated for new methods to replace models based on stationarity. Several studies have documented increases in low and median flows across the United States (McCabe and Wolock, 2002; Lins and Slack, 2005; Small and others, 2006), but trends in peak flows are less evident in the literature. In New England, Walter and Vogel (2010) found increasing high flows in urbanizing basins, but increasing high flows have also been shown by Hodgkins and Dudley (2005), Collins (2009), and Huntington and others (2009) in basins minimally affected by urbanization. Failing to take increasing trends in annual peak flows into account in a flood frequency analysis could potentially lead to the

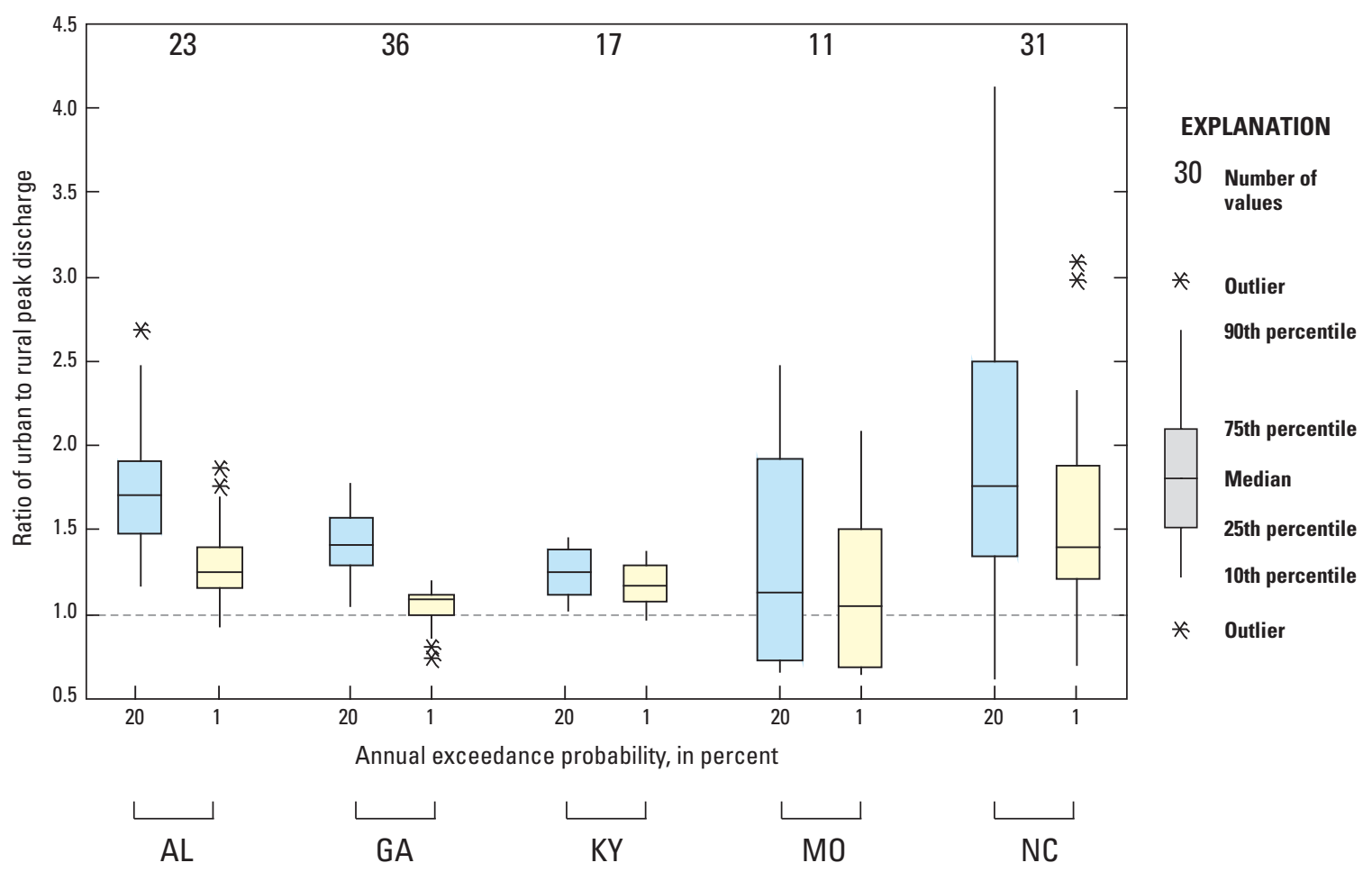

Figure 14. Ratio of urban to rural peak discharges for 20- and 1-percent annual exceedance probability flood in five states with separate flood flow equations. The variation of urban to rural flood flow ratios calculated in previous studies for Alabama (AL), Georgia (GA), Kentucky (KY), Missouri (MO), and North Carolina (NC) underscores the complex interaction of urbanization and other basin characteristics on peak runoff. 
underestimation of flood magnitudes or incorrect frequency of floods of a given magnitude, or both, at some point in the future.

Trends in annual peak flows were tested using Kendall's trend test (Helsel and Hirsch, 2002) for the 41 streamgages used in the regional flood flow analysis. The test indicated 76 percent of these streamgages had a statistically significant positive trend at the 95-percent confidence level (this includes the extended record at 23 streamgages). The Kendall-Theil robust line or Theil slope for sites with statistically significant trends ranged from 0.6 to 43 percent with a median slope of 4.0 percent. A subset of streamgages (16 sites) with 70 or more years of unregulated systematic record (table 12) indicate all but four sites have a statistically significant positive trend at the 95-percent confidence level with a Theil slope ranging from 3.2 to 28 percent with a median slope of 11 percent. Three of the other four streamgages have a statistically significant positive trend at about the 90-percent confidence level or above; only one streamgage, Little River near Hanover, CT (01123000), has a positive trend appreciably less than the 90-percent confidence level.

Plots of annual peak flows over time often mask trends because of normal variation in the magnitude of flows. An example plot (fig. 15A) of annual peak flows for Branch River at Forestdale, RI (01111500) shows little evidence of a trend; however, when a linear trend line was added (dashed blue line) to approximate the Kendall-Theil slope, the positive trend becomes apparent. When the annual peaks are identified by quartile range (fig. 15B), the plot indicates peaks within the interquartile and below the lower quartile have little or no trend, but peaks above the upper quartile have an appreciable upward trend. Plots of annual peaks at the other 15 long-term streamgages with statistically significant trends generally show similar patterns.

Table 12. Trends in annual peak flows at streamgages with 70 or more years of unregulated systematic recorded identified by the Kendall trend test.

[No., number; TAU, is a function of the number of positive (concordant) pairs minus the number of negative (discordant) pairs; $\mathrm{P}$, is the statistical test for significance; light shaded cells indicate trend was not significant above the 95-percent confidence level; dark shading indicates trend was not significant; RI, Rhode Island; CT, Connecticut; MA, Massachusetts]

\begin{tabular}{|c|c|c|c|c|c|c|c|}
\hline \multicolumn{2}{|r|}{ U.S. Geological Survey streamgage } & \multicolumn{3}{|c|}{ Record } & \multirow[b]{2}{*}{ TAU } & \multirow[b]{2}{*}{ P-value } & \multirow[b]{2}{*}{ Theil slope } \\
\hline Number & Name & Begin & End & $\begin{array}{l}\text { No. of } \\
\text { years }\end{array}$ & & & \\
\hline \multicolumn{8}{|c|}{ Rhode Island streamgages } \\
\hline 01111500 & Branch River at Forestdale, RI & 1940 & 2010 & 71 & 0.207 & 0.011 & 13.7 \\
\hline 01112500 & Blackstone River at Woonsocket, RI & 1929 & 2010 & 82 & 0.174 & 0.021 & 28.5 \\
\hline 01117500 & Pawcatuck River at Wood River Junction, RI & 1940 & 2010 & 70 & 0.233 & 0.004 & 14.3 \\
\hline 01118000 & Wood River at Hope Valley, RI & 1941 & 2010 & 69 & 0.247 & 0.003 & 6.3 \\
\hline 01118500 & Pawcatuck River at Westerly, RI & 1940 & 2010 & 70 & 0.233 & 0.004 & 14.3 \\
\hline 01114500 & Woonasquatucket River at Centerdale, RI & 1941 & 2010 & 69 & 0.268 & 0.001 & 6.3 \\
\hline 01116000 & South Branch Pawtuxet River at Washington, RI & 1940 & 2010 & 71 & 0.166 & 0.042 & 4.1 \\
\hline 01117000 & Hunt River near East Greenwich, RI & 1940 & 2010 & 71 & 0.334 & 0.000 & 3.2 \\
\hline \multicolumn{8}{|c|}{ Connecticut streamgages } \\
\hline 01119500 & Willimantic River near Coventry, CT & 1932 & 2010 & 79 & 0.124 & 0.107 & 11.2 \\
\hline 01123000 & Little River near Hanover, CT & 1952 & 2010 & 61 & 0.086 & 0.336 & 4.5 \\
\hline 01121000 & Mount Hope River near Warrenville, CT & 1941 & 2010 & 70 & 0.233 & 0.004 & 8.5 \\
\hline 01127500 & Yantic River at Yantic, CT & 1931 & 2010 & 81 & 0.164 & 0.031 & 16.1 \\
\hline 01193500 & Salmon River at East Hampton, CT & 1929 & 2010 & 83 & 0.233 & 0.002 & 22.9 \\
\hline \multicolumn{8}{|c|}{ Massachusetts streamgages } \\
\hline 01109000 & Wading River near Norton, MA & 1925 & 2010 & 86 & 0.121 & 0.103 & 1.6 \\
\hline 01105000 & Neponset River at Norwood, MA & 1939 & 2010 & 71 & 0.333 & 0.000 & 3.7 \\
\hline 01176000 & Quaboag River at West Brimfield, MA & 1912 & 2010 & 97 & 0.126 & 0.067 & 3.0 \\
\hline
\end{tabular}




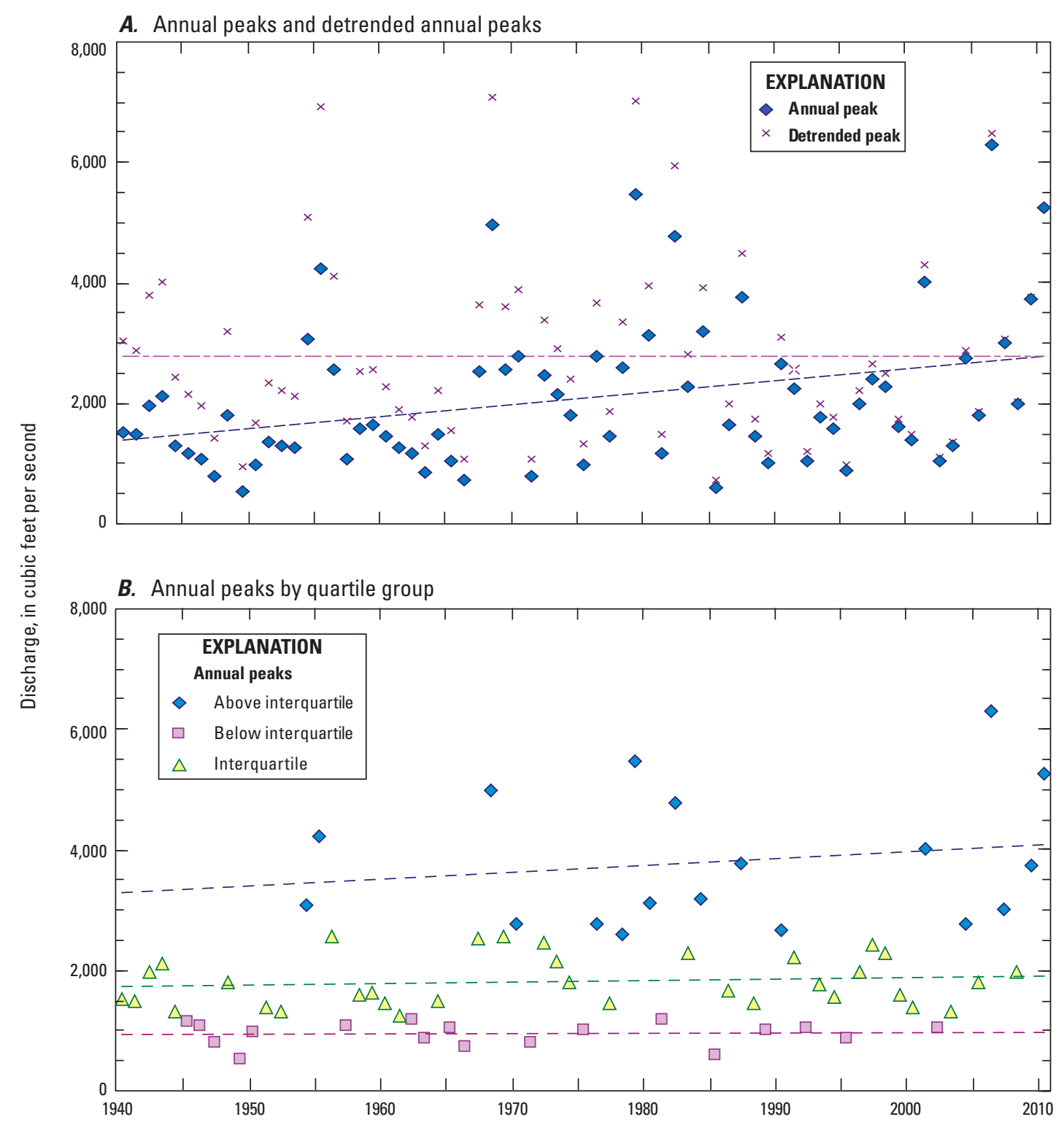

C. Decadal count of annual peak by quartile group

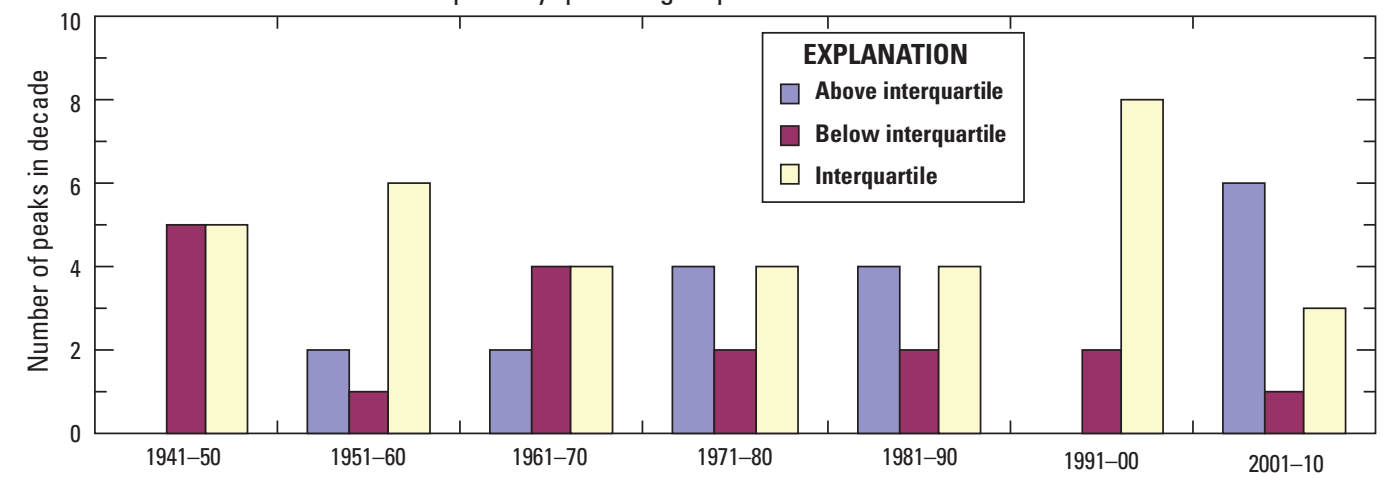

Figure 15. Trends in $A$, annual peak flows and detrended annual peaks, $B$, annual peak flows by quartile group, and $C$, decadal count of annual peak flows by quartile group for Branch River at Forestdale, RI (01111500). 
Histograms of the number of annual peak flows within each quartile group by decade (fig. 15C) generally indicate an increasing number of peaks in the upper quartile range over time and a decreasing number of peaks in the lower quartile over time. Decades of relatively high annual peaks (2001-10), low annual peaks (1941-50), and average annual peaks (1951-60 and 1991-2000) are also revealed. Similar patterns are seen in histograms (fig. 16) of the average number of annual peak flows within each quartile by decade at the 15 streamgages with statistically significant trends above about the 90-percent confidence level (table 12).

Several approaches for incorporating temporal trends into a flood frequency analysis have been discussed in the literature. One approach is to assume a parametric distribution for annual peak flows to model the parameters of the distribution as a function of time using linear regression (Katz and others, 2002) or nonlinear methods (Villarini and others, 2009; Ouarda and El-Adlouni, 2011). Another approach fits a locally weighted least squares (LOESS) smoothed curve to the annual peaks (Ries and Dillow, 2006). Data are adjusted by subtracting the difference between the LOESS line and each of the annual peaks from the final value of the LOESS curve to "detrend" the data, the hypothesis being that the trend is removed but the variance in the data is preserved. This effectively rotates the data upward (when the trend is positive) around a pivot point at the end of the data record as shown in figure 15A. This method appears to unduly affect normal cycles of relatively wet and dry periods and was not used to adjust peaks in this study.
Walter and Vogel (2010) developed magnification and recurrence reduction factors to examine how a linear trend would affect flood magnitudes and recurrence intervals at a future time. Peak flows at a streamgage were first modeled as a function of time using a log-linear regression. The quantile function calculates the flood magnitude at a given exceedance probability. In the presence of a linear trend, the log-normal quantile function may be expressed as a function of time by substituting the regression equation into the cumulative distribution function. The magnification factor is the ratio of the quantile function at a future time to the quantile function at present. After simplification of terms, the magnification factor can be expressed as a function of the slope of the regression and the time period, as follows:

$$
M=e^{\beta \times \Delta t},
$$

where

$$
\begin{aligned}
& M \quad \begin{array}{l}
\text { is the flood modification factor, that is, } \\
\text { the change in flood magnitude over a } \\
\text { specified time; }
\end{array} \\
& \beta \quad \begin{array}{l}
\text { is the slope of the lognormal regression of } \\
\text { annual peak flow and time; and }
\end{array} \\
& \Delta t \quad \text { is the projected time period. }
\end{aligned}
$$

The method assumes that the linear trend persists at the same rate over the projected time period and can be used to calculate the amount by which a given flood flow must be multiplied to represent a flood of the same exceedance probability over that time interval.

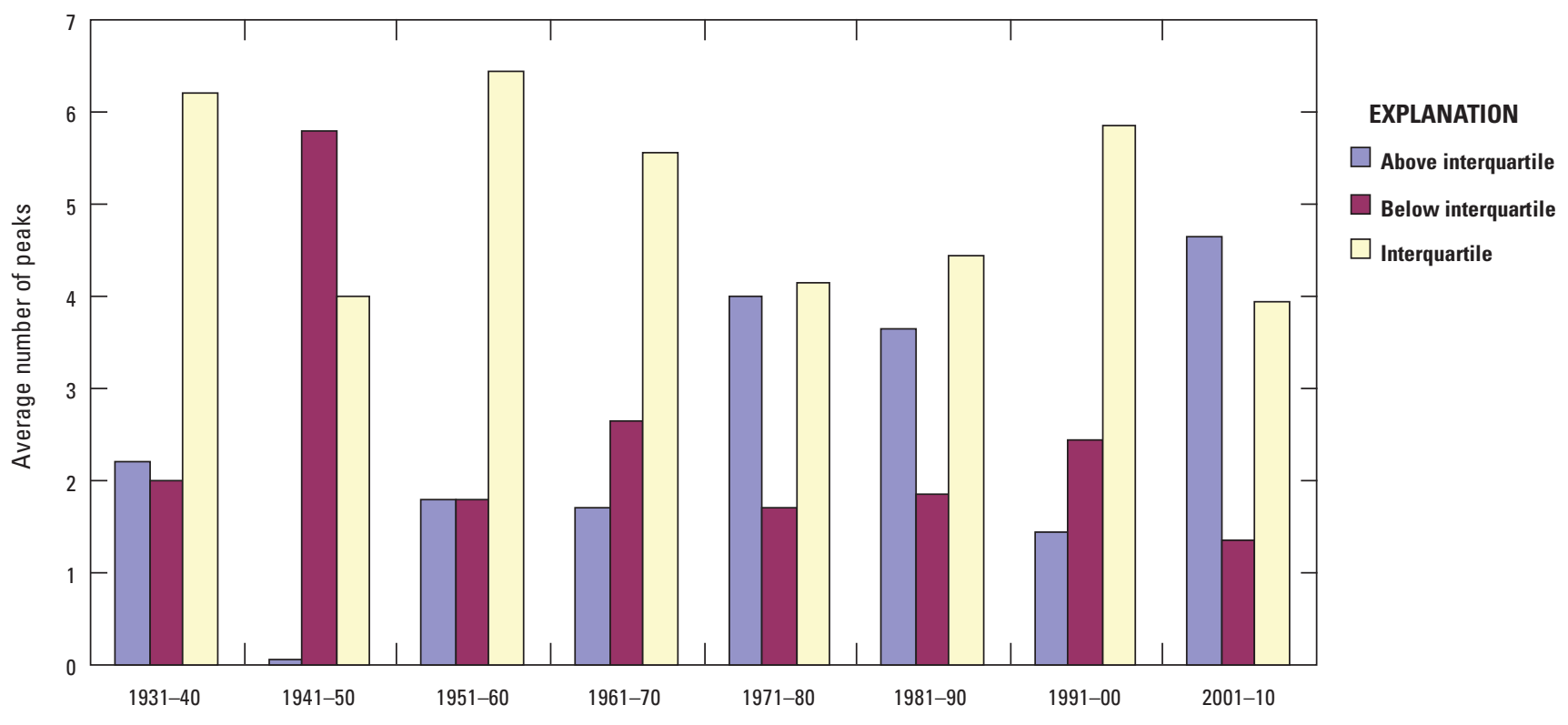

Figure 16. Average number of annual peak flows by decade by quartile range among 15 streamgages with statistically significant trends above about the 90-percent confidence level. 
The flood magnification factors (equation 18) were calculated at 15 unregulated streamgages with long-term records (table 12) with statistically significant trends. Flood magnification factors determined for 10-, 20-, and 30-year projections had computed means of 1.06, 1.13, and 1.21 respectively. In other words, if the linear trend in annual peak flows persists, the flood with a given exceedance probability will, on average, be 6,13 , and 21 percent greater in magnitude in 10,20 , and 30 years, respectively. The distribution of the flood magnification factors at the 15 streamgages projected for 10,20 , and 30 years out in the future are shown in figure $17 \mathrm{~A}$ with values ranging from 0.14 to 12 percent, 2.8 to 25 percent, and 4.3 to 39 percent for 10, 20, and 30 years out from 2010, respectively. The range in flood magnification factors can be applied to floods of any exceedance probability.

Alternatively, a recurrence reduction factor computes the change in the expected average return time of a flood based on a persistent linear trend. An increasing trend causes the average return time of a given magnitude flood to decrease in the future. Walter and Vogel (2010) define the recurrence reduction factor as the ratio of the return period of a given magnitude flood at some point in the future to the return period of the same magnitude flood at present. The return period of a flood is often misinterpreted, and therefore, its use
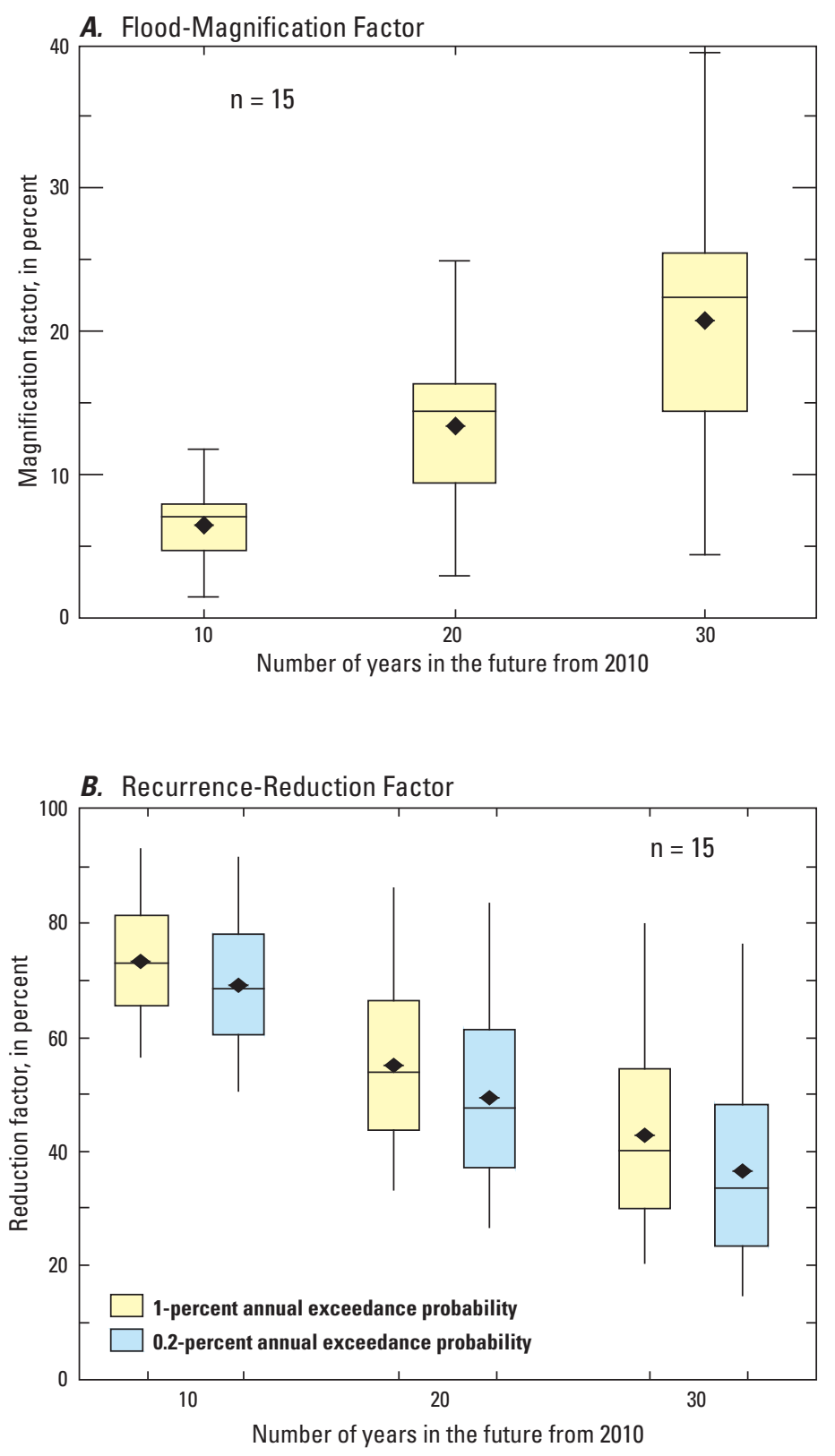

\section{EXPLANATION}

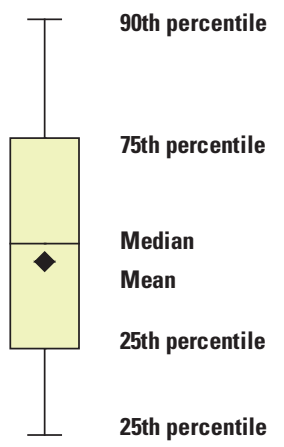

Figure 17. Projected influence of trends in annual peak flows at 15 long-term streamgages by the $A$, flood magnification factor and $B$, recurrence reduction factor. 
has diminished in recent flood frequency analyses but is used here for illustrative purposes. The recurrence reduction factor is the increase in frequency for a given magnitude flood in the presence of a trend derived by equating the quantile function for the present condition at a given exceedance probability to the quantile at a future period. For example, a 0.5 recurrence reduction factor during a 10 -year period would mean that a 100-year flood (1-percent AEP) would become a 50-year flood (2-percent AEP) in 10 years time. That is, a flood magnitude for a given AEP will likely occur twice as frequently if the trend persists at the 0.5 reduction factor rate.

Recurrence reduction factors calculated for 100- and 500-year floods were projected out for the 10-, 20-, and 30 -year periods (fig. 17B). The trend at the 15 unregulated streamgages with long-term records (table 12) with statistically significant trends, on average, indicate that a 100 -year flood at present (2010) would have an average return period of 73,55 , and 43 years when projected 10,20 , and 30 years in the future. A 500-year flood at present would have an average return period of 344,245 , and 182 years when projected 10,20 , and 30 years in the future. While these results can be unsettling, it should be emphasized that the change factors computed by the methods of Walter and Vogel (2010) assume the same linear trend, which may not continue over the projected time periods. True trends can only be determined by continued monitoring of streamflow. Statistical procedures for nonstationarity are in their infancy, and the trends observed in the data used in this study and its effects on flood frequency will require further work as this science evolves.

\section{Application of Methods and Significance of Results}

Floods are considered random events that have inherent uncertainties associated with the data, or lack thereof, and various errors and limitations of the statistical methods used to estimate the magnitude of floods for a given AEP. Our understanding of flood flows and the associated risks can be improved by applying the information gained from the streamgage flood frequency and the regional regression analyses. The analyses can also improve our understanding of flood flows at short-term streamgages not used in the analyses and exceedance probability of the 2010 flood in Rhode Island.

\section{Weighted Estimates of Flood Flows at Streamgages}

Flood flow estimates for a given AEP at streamgages, particularly those with short records, can be improved by a weighted average of two independent estimates from the streamgage analyses and the regional regression equations. The procedure assumes that the estimates are independent, which is considered true in most practical instances by Bulletin 17B. Exceptions may include regional regression equations based on clusters of streamgages in close proximity or with uniformly short periods of record; this does not appear to be a factor in this analysis. If the at-site and regression flood flow statistics are not independent, then the variance of a weighted estimate will be larger than the variance of each estimate. Also note that if basin characteristics are outside the range of characteristics used in the regional regression or if the high flows at a streamgage are appreciably affected by regulation, then a weighted estimate should not be made.

In the past, the weights for flood flow estimates were often made based on the number of years of record used to determine the at-site estimate and the equivalent years of record for the regression equation. The equivalent years of record is an approximation of the gage record needed to achieve accuracy comparable with that of the regression model (Tasker and Stedinger, 1989). This approach often fails to account for the true variance of the respective flood flow estimate and the information content provided by the regional skew. For example, the variance of the annual peak flow record will determine the reliability of the probability distribution even for streamgage records of equal length.

A weighted estimate can be calculated from the variance of independent estimates, which can be viewed as a measure of the uncertainty. When the variance corresponding to one of the estimates is high, the uncertainty is high and the weight applied to that estimate should be relatively small. Conversely, when the variance is low, the uncertainty is low and the weight applied to that estimate should be relatively large. Thus, the optimum weight is inversely proportional to the variance of each flood flow estimate, which is described in Bulletin 17B and can be calculated from the $\log _{10}$ of flood flows and variances as follows:

$$
Q_{w g t}=\frac{\left(Q_{\text {site }} \times V_{r e g}\right)+\left(Q_{\text {reg }} \times V_{\text {site }}\right)}{V_{\text {site }}+V_{r e g}},
$$

where

$Q_{w g t} \quad$ is the weighted flow estimate for a given AEP,

$Q_{\text {site }} \quad$ is the at-site flow estimate for a given AEP,

$Q_{\text {reg }} \quad$ is the regional regression flood flow estimate for a given AEP,

$V_{\text {site }} \quad$ is the variance of the at-site estimate for a given AEP, and

$V_{r e g} \quad$ is the variance of the regional regression estimate for a given AEP.

Similarly, a weighted variance can be calculated from the inverse variances of each flood flow estimate by:

$$
V_{w g t}=\frac{V_{\text {site }} \times V_{r e g}}{V_{\text {site }}+V_{r e g}}
$$


There are a number of variables needed to calculate the variance of the at-site and regional regression flood flow estimates. The at-site variance is based on the number of peak flow observations and the $\log _{10}$ values of the mean, standard deviation, and skew determined by the B17B or the EMA analysis and the RMSE of the regional skew used. In this analysis, the regional regression variance is determined from the standard error of the model, the number of explanatory variables, and the covariance matrix $(U)$ of the explanatory variables used in equation. To facilitate the computation of the weighted estimate (equation 19), the USGS developed the Weighted Independent Estimator (WIE) program (Cohn and others, 2012).

Weighted estimates of 20-, 10-, 4-, 2-, 1-, 0.5-, and 0.2-percent AEP flood flows were calculated using the WIE and are reported in table 13 (in back of report) for the Rhode Island streamgages reported in table 7 (in back of report); the WIE values in table 13 (in back of report) are the arithmetic transformation of the $\log _{10}$ values of flow computed in equation 19. For comparison, the at-site and regression flood flows along with the percent difference between the at-site value and WIE values also are reported. A positive difference indicates the weighted estimate is greater than the at-site estimate, and conversely, a negative value indicates the weighted estimate is smaller than the at-site estimate. Differences between the magnitude of floods determined from the at-site and weighted estimates progressively increase as the exceedance probability decreases (fig. 18); differences at the 0.2-percent AEP flows were largest and ranged from -45 to 23 percent. A flood with a 20-percent $\mathrm{AEP}$ has an interquartile range of -1.0 to
1.4 percent, whereas a flood with a 0.2 -percent AEP has an interquartile range of -16 to 5.8 percent. The increasing difference with decreasing flood probability is attributed to the greater uncertainty of flood flows as the AEP decreases.

\section{Flood Flows at Streamgages with Limited Record}

Flood magnitudes determined at streamgages with short records are subject to greater inaccuracies because the statistical properties of the record are less likely to reflect long term conditions. This is referred to as the sampling error of the true population, and the effects of the sampling error are mitigated to some extent by a skew weighted to the generalized skew representative of the region. The weighted skew is inversely proportional to the variance of each estimate as described in Bulletin 17B; however, this procedure is not without flaws because the true variance may not be accurately represented, particularly for streamgages with short records. Streamgages with short records can be extended using MOVE to better reflect long-term conditions, as was done for 23 of streamgages used in the study; however, the extrapolated record is made with less confidence as the concurrent shortand long-term streamgage record decreases. The regional flood frequency analysis did not include all the available short-term streamgages initially complied for the study because of the greater uncertainties associated with these streamgages and because of the limited number of index stations available for record extension. Still, flood flow estimates at short-term

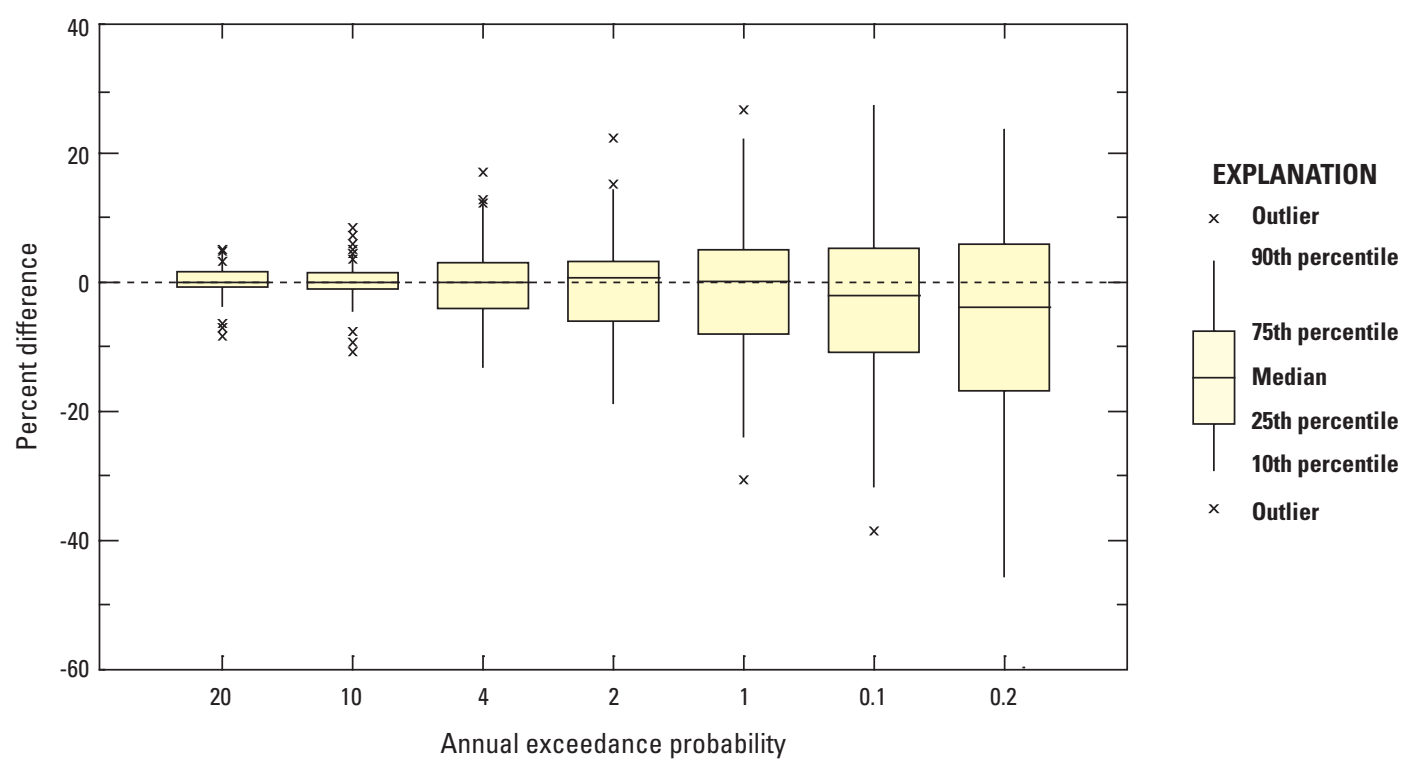

Figure 18. Range of differences between flood flows calculated from at-site analysis of annual peak flows and weighted independent estimate for selected annual exceedance probabilities. 
streamgages provide additional information for flood insurance studies, infrastructure design, and other purposes in basins with short-term streamgages not used in the regional analysis.

In preparation of the Johnson and Laraway (1977) flood frequency study, 20 streamgages were established in Rhode Island that generally ran between the mid-1960s and mid-1970s. The drainage area for these streams ranged from 0.5 to $7.33 \mathrm{mi}^{2}$ with a median of $3.1 \mathrm{mi}^{2}$ (table 14). While data for small basins are generally lacking, the record at these streamgages has a median length of 9 years. Three streamgages established later for other purposes have been in operation 10,12, and 16 years with drainage areas of 3.6, 20 , and $5.0 \mathrm{mi}^{2}$, respectively (table 14). In 2010, 17 other streamgages were in operation in Rhode Island that were not compiled because they have a record of less than 6 years, but could be of value in future flood frequency studies.
The distribution of flood flows was estimated at 19 of the short-term streamgages using B17B analysis of the systematic record, $\mathrm{B} 17 \mathrm{~B}$ and EMA analysis of the extended record, and the regional regression equation regardless of its applicability to the site (table 15, in back of report). That is, many of these short-term streamgages had basin characteristics outside the range applicable to the regional flood flow equations, particularly drainage area size. Four of the short-term streamgages (Metacomt Brook at East Providence, RI-01109300; Mowry Painc Brook near Chepachet, RI-01111450; Shippee Brook tributary at North Foster, RI-01115200; Furnace Hill Brook at Cranston, RI-01116870) were not included in the analysis because of suspect data quality (for example, the annual peak flows are excessively large for drainage basins of that size and showed little variation over the period data was collected). Thirteen of the 19 streamgages have basin characteristics outside of the range of characteristics used to develop the

Table 14. Streamgages with short-term records in Rhode Island that were not used in the regional flood frequency analysis.

[DA, drainage area; $\mathrm{mi}^{2}$, square miles; STRDEN, stream density; $\mathrm{mi} / \mathrm{mi}^{2}$, miles per square mile; StorNHD, storage; trib, tributary; --, not determined; 17 other streamgages are in the U.S. Geological Survey peak-flow database but with no greater than 6 years record]

\begin{tabular}{|c|c|c|c|c|c|c|c|}
\hline \multicolumn{2}{|r|}{ U.S. Geological Survey streamgage } & \multicolumn{3}{|c|}{ Record } & \multirow{2}{*}{$\begin{array}{c}\text { DA } \\
\left(\mathrm{mi}^{2}\right)\end{array}$} & \multirow{2}{*}{$\begin{array}{l}\text { STRDEN } \\
\left(\mathrm{mi} / \mathrm{mi}^{2}\right)\end{array}$} & \multirow{2}{*}{$\begin{array}{l}\text { StorNHD } \\
\text { (percent) }\end{array}$} \\
\hline Number & Name & Begin & End & Years & & & \\
\hline 01106100 & Cold Brook near Adamsville, RI & 1966 & 1973 & 9 & 1.15 & 2.86 & 5.64 \\
\hline 01111250 & Dry Arm Brook near Wallum Lake, RI & 1966 & 1978 & 13 & 1.74 & 2.20 & 14.69 \\
\hline 01111450 & Mowry Painc Brook near Chepachet, RI ${ }^{\mathrm{a}}$ & 1966 & 1973 & 9 & 1.87 & -- & -- \\
\hline 01113695 & Catamint Brook at Cumberland, RI & 2000 & 2010 & 10 & 3.55 & 2.29 & 5.99 \\
\hline 01115098 & Peeptoad Brook near North Scituate, RI & 1994 & 2010 & 16 & 4.96 & 1.68 & 17.15 \\
\hline 01115100 & Mosquitohawk Brook near North Scituate, RI & 1965 & 1974 & 9 & 3.06 & 2.41 & 17.18 \\
\hline 01115200 & Shippee Brook trib at North Foster, RI ${ }^{\mathrm{a}}$ & 1966 & 1974 & 9 & 2.42 & -- & -- \\
\hline 01116300 & Furnace Hill Brook at Cranston, $\mathrm{RI}^{\mathrm{a}}$ & 1965 & 1974 & 9 & 4.19 & 2.39 & 5.29 \\
\hline 01116600 & Pocasset River near North Scituate, RI & 1966 & 1978 & 13 & 1.34 & 3.10 & 10.66 \\
\hline 01116650 & Hardig Brook near W. Warwick, RI & 1966 & 1973 & 9 & 3.19 & 2.00 & 1.48 \\
\hline 01116870 & Frenchtown Brook near Davisville, RI & 1966 & 1973 & 9 & 3.12 & 2.15 & 6.75 \\
\hline 01117250 & Browns Brook at Wakefield, RI & 1966 & 1973 & 9 & 0.5 & 0.53 & 13.30 \\
\hline 01117370 & Queen River at Liberty, RI & 1998 & 2010 & 12 & 19.6 & 1.73 & 4.42 \\
\hline 01117600 & Meadow Brook near Carolina, RI & 1965 & 1974 & 11 & 5.53 & 1.67 & 9.15 \\
\hline 01117820 & Wood River trib near Arcadia, RI & 1966 & 1973 & 9 & 0.77 & 1.46 & 1.87 \\
\hline 01118020 & Perry Healy Brook near Bradford, RI & 1966 & 1973 & 9 & 1.82 & 1.48 & 12.84 \\
\hline
\end{tabular}

${ }^{\text {aS }}$ uspect peak flow record. 
regional regression equations, mostly because drainage areas were about 20 to 90 percent smaller than the minimum drainage area $\left(4.0 \mathrm{mi}^{2}\right)$ used in the regional regression. At these streamgages, regional regression estimates were reported, but no uncertainty limits or weighted estimates are given because the equations were applied to basins outside the appropriate limits of the equations.

Results indicate a wide variation between the flood estimates by method and by site with similar drainage areas. Generally, flood flows differed less between the period of record and extended record estimates than between extended record and regression estimates. Differences between the period of record and extended record estimates ranged from -46 to 37 percent and from -64 to 251 percent for 20 - and 0.2 -percent AEPs, respectively. Differences between the extended record and regression estimates ranged from -83 to 345 percent and from -89 to 541 percent for 20 - and 0.2-percent AEPs, respectively. Differences between methods at a site tended to be consistent across the range of AEP flows. Generally, the flood flow information from the shortterm streamgage can be used with greater confidence when the differences between methods are small. The results also indicate the need for additional data in small basins.

The streamgage at Carr River near Nooseneck, RI (01116600) was established in 1964, discontinued in 1980 , and reactivated in 2006. Collectively, the Carr River streamgage has 20 years of annual peak flows that provide a reasonable length of record to independently verify the regional regression equations for a small basin; the drainage area at the streamgage is $6.74 \mathrm{mi}^{2}$. The same regional skew (0.52) and RMSE (0.46) applied elsewhere this study was used in this at-site analysis. The magnitude of flood flows determined by a $\mathrm{B} 17 \mathrm{~B}$ analysis for the period of record on average was 37 greater than that determined from the extended record analysis; flows ranged from 27 to 45 percent greater for 20- and 0.2-percent AEP, respectively. Carr River records were extended back to 1941 using MOVE and the Hunt River near East Greenwich, RI (01117000) as the index streamgage; the MOVE fit reasonably well with a correlation coefficient of 0.89 and an RMSE of $60 \mathrm{ft}^{3} / \mathrm{s}$. Flood magnitudes derived from the regional regression equation were consistently less than those computed from the period of record B17B analysis; flows ranged from 18 to 71 percent less for 20- and 0.2-percent AEP, respectively. On the other hand, the regression equation flood magnitudes compared with the extended record $\mathrm{B} 17 \mathrm{~B}$ analysis were 13 percent greater at the 20-percent AEP, matched the 10-percent AEP, and were progressively smaller (14 to 48 percent) from the 4 - to 0.2-percent AEP, respectively. All but the 0.5- and 0.2-percent AEP regional regression flows for this streamgage were within the percent average standard error of prediction.

\section{Flood Flows at an Ungaged Site on a Gaged Stream}

Estimates of flood flows on a stream above or below a gaged location, within limits, can be improved by combining the streamgage information with the regional regression equation. Verdi and Dixon (2011) present a method for better estimating flows at an ungaged site on a gaged stream from Sauer (1974) for streamgages with a record of 10 or more years (equation 21). To obtain a weighted peak-flow estimate $\left(Q_{P(u) w}\right)$ for an AEP at the ungaged site, the flood flow estimate for an upstream or downstream gaged $\left(Q_{P(g) w}\right)$ must first be determined by the at-site analysis (table 7 , in back of report) adjusted by the WIE analysis reported in table 13 (in back of report). Streamgages in Rhode Island with short records not included in the regional analysis are listed in table 14, but most should not be used because they have drainage areas outside the applicable limits of the regional regression equations. The weighted estimate for the ungaged site $\left(Q_{P(u) w}\right)$ on a gaged stream is then computed as follows:

$$
Q_{P(u) w}=\left[\left(\frac{2 \Delta D A}{D A_{g}}\right)+\left(1-\frac{2 \Delta D A}{D A_{g}}\right)\left(\frac{Q_{P(g) w}}{Q_{P(g) r}}\right)\right] Q_{P(u) r},
$$

where

$Q_{P(u) w} \quad$ is the flow estimate for the selected P-percent AEP at the ungaged site, in cubic feet per second;

$\triangle D A \quad$ is the absolute difference between the drainage areas at the gaged and ungaged sites, in square miles;

$D A_{g} \quad$ is the drainage area for the gaged site, in square miles;

$Q_{P(g) w} \quad$ is the weighted flow at the streamgage derived from at-site analysis and regional regression equations for the selected P-percent AEP (table 13, in back of report), in cubic feet per second;

$Q_{P(g) r} \quad$ is the flow estimate derived from the applicable regional equations 2-8 for the selected P-percent AEP at the gaged site, in cubic feet per second; and

$Q_{P(u) r} \quad$ is the flow estimate derived from the applicable regional equations 2-8 for the selected P-percent AEP at the ungaged site, in cubic feet per second.

Use of equation 21 gives no weight to the at-site estimate when the drainage area ratio between the gaged and ungaged sites are less than 0.5 or greater than 1.5 and gives increased weight to the at-site estimate as the drainage area ratio approaches 1 . The weighting procedure should not be used when hydrologic characteristics abruptly change, such as a large instream impoundment between the sites. 
An example application of this procedure is the computation of the weighted 1-percent AEP flow, for a hypothetical site on the Wood River above Hope Valley, RI (01117500) streamgage. For simplicity and comparative purposes, the example assumes the ungaged site is the streamgage at Wood River at Arcadia, RI (01117800). It also should be noted that the Wood River at Arcadia streamgage was not used in the development of the regionalized flood flow equations because of its high correlation with the downstream streamgage at Hope Valley.

1. Obtain the value of $Q_{1 \%(g) w}$ for the streamgage in table 13 (in back of report) $\left(=3,160 \mathrm{ft}^{3} / \mathrm{s}\right)$

2. Obtain the $\triangle D A$ between the gaged and ungaged sites $\left(=74.53-35.14=39.39 \mathrm{mi}^{2}\right)$

3. Compute the regional regression $\left(Q_{1 \%(u) r}\right)$ for the ungaged site using equation 6

$\left(=10^{\left(2.623+\left(0.852 \times \log _{10}(35.14)\right)+\left(0.792 \times \log _{10}(1.35)\right)-\left(0.941 \times \log _{10}(7.84)\right)\right)}\right.$

$$
\left.=1,590 \mathrm{ft}^{3} / \mathrm{s}\right)
$$

4. Compute the regional regression $\left(Q_{1 \%(g) r}\right)$ for the gaged site using equation $5\left(=3,200 \mathrm{ft}^{3} / \mathrm{s}\right)$ and

5. Compute the weighted estimate for the ungaged site $\left(Q_{1 \%(u) w}\right)$ using equation 21

$$
\begin{gathered}
\left(\frac{2 \times-39.39}{74.53}+\left(\left(1-\frac{2 \times-39.39}{74.53}\right) \times \frac{3,160}{3,200}\right) \times 1,590\right. \\
=1,590 \mathrm{ft}^{3} / \mathrm{s} .
\end{gathered}
$$

The adjusted discharge $\left(1,590 \mathrm{ft}^{3} / \mathrm{s}\right)$ at the "ungaged" site determined by equation 21 is no different than the computed value from the regional regression $\left(1,590 \mathrm{ft}^{3} / \mathrm{s}\right)$ because the drainage area at the "ungaged" site is under the lower limit of the drainage area ratio (0.47); thus, all the weight is put on regional regression flow value.

A similar, but simpler approach used in StreamStats (an interactive online tool for solving regionalized equations; Ries and others, 2008) is used to adjust flood flows on the basis of the drainage area ratio at the gaged and ungaged sites on the same stream. The weighting procedure should not be applied when the drainage area ratio is less than 0.5 or greater than 1.5 or when hydrologic characteristics abruptly change between the sites. The adjustment method for a site above or below a gaged location in StreamStats goes at least a far back as the Elements of Applied Hydrology (Johnstone and Cross, 1949):

$$
Q_{P(u) w}=\left(\frac{D A_{u}}{D A_{g}}\right)^{b} Q_{P(g) w},
$$

where

$$
\begin{gathered}
Q_{P(u) w} \quad \begin{array}{l}
\text { is the flow estimate for the selected P-percent } \\
\text { AEP at the ungaged site, in cubic feet per } \\
\text { second; }
\end{array} \\
D A_{u} \quad \text { is the drainage area at the ungaged site, in } \\
\text { square miles; } \\
D A_{g} \quad \text { is the drainage area at the streamgage, in } \\
\text { square miles; } \\
Q_{P(g) w} \quad \begin{array}{c}
\text { is the weighted flow estimate for the selected } \\
\text { P-percent AEP at the ungaged site, in cubic } \\
\text { feet per second; and }
\end{array} \\
\text { is the exponent of drainage area from the } \\
\text { appropriate regression equations. }
\end{gathered}
$$

Exponents from regional flood flow equations derived from WREG using a GLS analysis of drainage area range from 0.76 to 0.80 (table 16 ). The average exponent $b$ over the range of exceedance probabilities ( 0.78 in this study) is used by some in equation 22 to obtain a weighted estimate of a flood flow at an ungaged site on a gaged stream for any exceedance probability flood. Solving equation 22 for Wood River at Arcadia (the "ungaged" site) yields a discharge of $1,770 \mathrm{ft}^{3} / \mathrm{s}$ $\left(=[35.14 / 74.53]^{0.77} \times 3,160\right)$ for the 1-percent AEP flow. The adjusted 1-percent AEP flow is about 11 percent larger than the computed magnitude from the regional regression equation $\left(1,590 \mathrm{ft}^{3} / \mathrm{s}\right)$ and about 8 percent larger than the weighted at-site flood magnitude $\left(1,640 \mathrm{ft}^{3} / \mathrm{s}\right)$.

Table 16. Regional exponent for drainage area adjustment of a flood flows at an ungaged site on gaged stream determined from the regional regression of drainage area.

[Note, the constant is not used in the drainage area ratio adjustment but could be used to estimate flood flows at ungaged site from drainage area only]

\begin{tabular}{ccc}
\hline $\begin{array}{c}\text { Percent annual } \\
\text { exceedance } \\
\text { probability }\end{array}$ & Exponent $\boldsymbol{b}$ & Constant \\
\hline 20 & 0.81 & 1.76 \\
10 & 0.80 & 1.88 \\
4 & 0.79 & 2.04 \\
2 & 0.78 & 2.14 \\
1 & 0.77 & 2.23 \\
0.5 & 0.77 & 2.32 \\
0.2 & 0.76 & 2.42 \\
\hline
\end{tabular}


In some instances, equation 21 can produce flows that do not increase in the downstream direction when the change in drainage area is small and the change in basin storage is large. This is because, in the underlying regional regression used in equation 21 (equations 2-8), basin storage (StorNHD) is a negative term, which causes the flood quantile to decrease as StorNHD increases. Although, this can be true, some applications require flows increase in the downstream direction and care should be taken to ensure the desired result. A hybrid of equations 21 and 22 presented by Guimaraes and Bohman (1992) and Stamey and Hess (1993) can be used to ensure increasing flow in the downstream direction:

$$
Q_{P(u) w}=\left[\left(\frac{2 \Delta D A}{D A_{g}}\right) Q_{P(u) r}+\left(1-\frac{2 \Delta D A}{D A_{g}}\right)\left(\frac{D A_{u}}{D A_{g}}\right)^{b} Q_{P(g) w}\right] .
$$

Similar to the other methods, this method only applies when the ungaged site is within 0.5 and 1.5 times the drainage area of the streamgage and there is no major change in basin characteristics between sites. Using the same example as before, equation 23 yields an adjusted discharge of $1,580 \mathrm{ft}^{3} / \mathrm{s}$, which is about 4 percent less than the WIE flow $\left(1,640 \mathrm{ft}^{3} / \mathrm{s}\right)$ at Wood River at Arcadia, RI (01117800) determined from the at-site analysis weighted by the regional regression equation (table 13, in back of report).

A spreadsheet for solving the flood flows for a given exceedance probability on a stream above or below a gaged location by these methods can be accessed through a hyperlink in appendix 3. The equation 21 requires user specified drainage area at the gaged and ungaged sites, regional regression estimated flood magnitudes for the ungaged and gaged sites for a given exceedance probability, and flood magnitude determined from the streamgage analysis for the same exceedance probability. Equation 23 is solved simultaneously with equation 21, but does not require the regional regression estimated flood magnitude at the streamgage. The drainage area ratio method (equation 22) only requires user specified drainage areas at the gaged site and flood magnitude determined from the streamgage analysis for a given exceedance probability at the gaged site. In this test example, the "ungaged" site, which is actually a long-term streamgage, the more complex method (equation 23) was marginally closer to the at-site flood flow estimate than the simpler method (equation 22).

For an ungaged site that is between two gaged sites on the same stream, two flow estimates can be made using the methods and criteria outlined above, but additional hydrologic judgment may be necessary to determine which method and estimates (or some interpolation thereof) are most appropriate. Only a few rivers in Rhode Island have multiple gages to apply multiple adjusted estimates of flood flows at an ungaged site on a gaged stream, such as Pawcatuck River between Westerly and Wood River Junction and Wood River between Hope Valley and Arcadia. Other factors that should be considered when evaluating the two estimates include differences in the length of record for the two streamgages and the quality of the peak flow record.

\section{Comparison with a Previous Rhode Island Flood Study}

With the development of updated at-site flood statistics and regional regression relations, a question that arises is how have results changed between previous and updated analyses. Comparisons were made for flood magnitudes at the 10-, 1-, and 0.2-percent exceedance probabilities using the 18 Rhode Island streamgages in this study (table 7 , in back of report), 10 of which had been used in the previous study by Johnson and Laraway (1977), which was intended for use in small drainage basins (less than about $10 \mathrm{mi}^{2}$ ) and for frequent floods (the data used in that study only spanned 6 years of record from 1966-71). Regression equations had been developed for 50and 20-percent AEP floods and were then extrapolated to 10-, 4-, and 2-percent AEP floods using factors presented by Green (1964). Further extrapolations were made to a 1-percent AEP flood when the equations were incorporated into the NFF program (Jennings and others, 1994) and to a 0.2-percent AEP flood when NFF was replaced by the National Streamflow Statistics (NSS) program (Ries and Crouse, 2002).

Comparisons were made between the flood magnitudes obtained from the at-site analyses determined from the weighted skew coefficient and the regional regression equations in this report. A second comparison was made between the at-site flows and those calculated from the previous Rhode Island flood flow equations, and a third comparison was made between the updated and previous flood flow equations. The distribution of the differences between the at-site analyses, the updated equations, and the previous regional equations are shown by boxplots in figure 19 .

Positive differences indicate that the updated regression equation results are greater than the at-site results or previous regression equation results; negative percentage differences indicate that the updated regression equation results are smaller than the at-site results or previous regression equation results. Most notable is that the median difference in values between the updated regional equation and the at-site analyses 


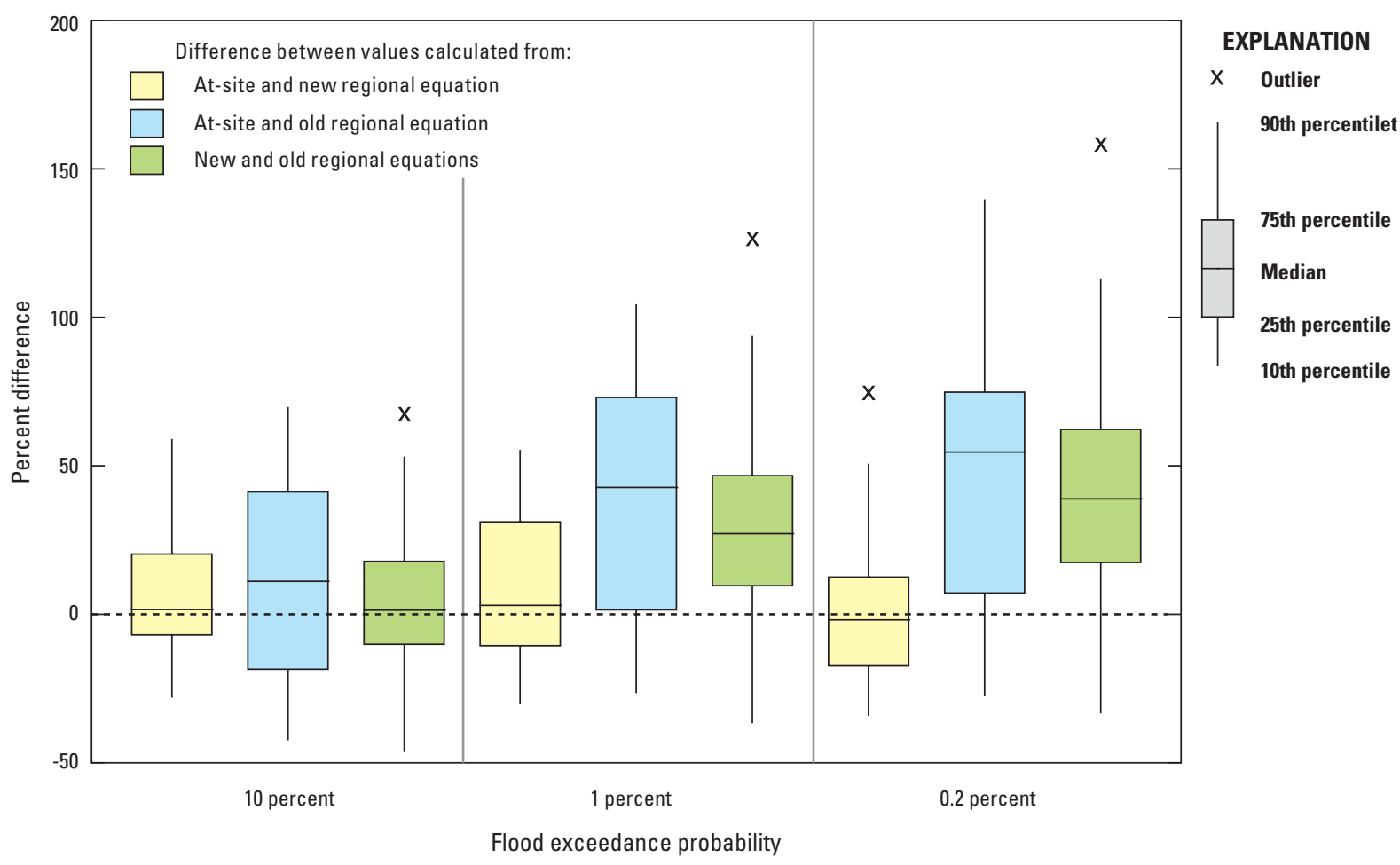

Figure 19. Differences from at-site analyses and regional regression equations in this study and regression equations from previous study by Johnson and Laraway (1977) for 18 streamgages in Rhode Island (table 7) for 10-, 1-, and 0.2-percent annual exceedance probability floods.

are near zero, whereas the median difference between the previous regional equation and the at-site analyses are appreciably higher than zero. Hence, the previous equations generally produce larger flows than the updated equations, particularly as the exceedance probability decreases, underscoring the limitation of how the previous regression equations were developed. At the 1- and 0.2-percent AEP, the median differences between the at-site analyses and previous flood equations are about 43 and 55 percent, respectively, and the lower quartile is above the zero line. Generally, the large differences between the updated and previous flood flow equations can be explained by the additional record used in the analyses and the disproportional number of the highest peaks in the years following the end of the record used in the previous study. These differences highlight the need to periodically update flood flow statistics and regional regression equations.

\section{Annual Exceedance Probability of the $\mathbf{2 0 1 0}$ Flood in Rhode Island}

One of the purposes of this study was to determine the annual exceedance probability of the 2010 flood in Rhode Island. Of the 21 active streamgages in Rhode Island in 2010, 18 set new record peak flows (table 17) with AEPs ranging from 2 to 0.2 percent (50- to 500 -year return interval, respectively). Most 2010 peak flows were between a 0.5 - and 0.2-percent AEP except for streamgages in the Blackstone River Basin, which lie in the northern part of Rhode Island and in Massachusetts and did not set new record peak flows during the 2010 flood; the AEP of the peak flows at these streamgages ranged from 4 and 2 percent (25- to 50-year return interval, respectively). 
Table 17. March-April 2010 flood peak and annual exceedance probability at active streamgages in Rhode Island.

[Values in bold typeface indicate new peak of record. AEP, annual exceedance probability determined from weighted estimates in table 7. $\mathrm{ft}^{3} / \mathrm{s}$, cubic feet per second; \%, percent; R, river; Ave., Avenue; Rd., Road; RI, Rhode Island; nr, near; --, not determined]

\begin{tabular}{|c|c|c|c|c|c|c|c|c|}
\hline \multicolumn{2}{|r|}{ U.S. Geological Survey streamgage } & $\begin{array}{l}\text { Start of } \\
\text { record }\end{array}$ & \multicolumn{4}{|c|}{2010 Flood peak } & \multicolumn{2}{|c|}{ Previous record peak } \\
\hline \multicolumn{9}{|c|}{ Ten Mile River Basin } \\
\hline 01109403 & Ten Mile R, Pawtucket Ave. at East Providence, RI & 1986 & 03/31/2010 & 10.79 & 2,600 & 1 & 2,190 & $10 / 16 / 2005$ \\
\hline 01111300 & Nipmuc River near Harrisville, RI & 1964 & $03 / 30 / 2010$ & 8.29 & 1,800 & 2 & 1,870 & $10 / 15 / 2005$ \\
\hline 01111500 & Branch River at Forestdale, RI & 1940 & $03 / 31 / 2010$ & 12.05 & 5,260 & 4 & 6,290 & $10 / 15 / 2005$ \\
\hline 01112500 & Blackstone River at Woonsocket, RI & 1929 & $03 / 31 / 2010$ & 14.50 & 14,900 & 4 & $32,900^{\mathrm{a}}$ & 08/19/1955 \\
\hline \multicolumn{9}{|c|}{ Pawtuxet, Woonasquatucket, Moshassuck, and Hunt River Basins } \\
\hline 01115187 & Ponaganset River at South Foster, RI & 1994 & 03/14/2010 & 6.57 & 1,330 & 2 & 1,110 & $06 / 17 / 2001$ \\
\hline 01115630 & Nooseneck River at Nooseneck, RI & $1964^{\mathrm{b}}$ & 03/30/2010 & 5.32 & 1,020 & 0.2 & 762 & 08/11/2008 \\
\hline 01116000 & South Branch Pawtuxet River at Washington, RI & 1940 & $03 / 31 / 2010$ & 9.22 & 5,480 & 0.2 & 1,980 & 06/06/1982 \\
\hline 01116500 & Pawtuxet River at Cranston, RI & 1939 & $03 / 31 / 2010$ & 20.79 & 14,900 & $0.2^{\mathrm{c}}$ & 5,440 & 06/07/1982 \\
\hline 01117000 & Hunt River near East Greenwich, RI & 1940 & $03 / 30 / 2010$ & 5.61 & 2,380 & 0.2 & 1,680 & $10 / 15 / 2005$ \\
\hline \multicolumn{9}{|c|}{ Pawcatuck River Basin } \\
\hline 01117350 & Chipuxet River at West Kingston, RI & 1973 & 03/31/2010 & 9.78 & 748 & 0.2 & 306 & $10 / 16 / 2005$ \\
\hline 01117800 & Wood River near Arcadia, RI & 1964 & $03 / 31 / 2010$ & 10.56 & 2,650 & 0.2 & 1480 & $06 / 06 / 1982$ \\
\hline 01118000 & Wood River at Hope Valley, RI & 1941 & 03/30/2010 & 13.72 & 5,470 & 0.2 & 2,390 & 06/06/1982 \\
\hline 01118500 & Pawcatuck River at Westerly, RI & 1940 & $03 / 30 / 2010$ & 15.38 & 10,800 & 0.2 & 7,070 & 06/06/1982 \\
\hline
\end{tabular}

aPreviously coded as a dam break, but recent inspection of the record indicates this had little effect on the peak.

${ }^{\text {b}}$ Ended in 1981 and restarted in 2007.

'Determined from at-site flood analysis. 


\section{Summary and Conclusions}

A statewide disaster was declared for Rhode Island by the President on March 30, 2010, following heavy persistent rains from late February through March 2010 that caused severe flooding and set, or nearly set, record streamflows and water levels at many long-term streamgages in the state. Following floods of this severity, updating and documenting the magnitude of annual exceedance probability (AEP) floods is important for flood plain management, transportation infrastructure design, and flood insurance studies to help minimize future flood damages and risks. In August 2010, the U.S. Geological Survey (USGS) entered into an agreement with the Federal Emergency Management Agency to document and characterize the March-April 2010 flood. As part of that agreement, a study was conducted to estimate the magnitude of flood flows at selected AEPs at streamgages in Rhode Island and to develop statewide regional equations for estimating flood flows at ungaged locations.

To better represent the Rhode Island region, the magnitude of floods were determined at 43 streamgages including 20 in Rhode Island, 14 in eastern Connecticut, and 9 in southeastern and south central Massachusetts. At-site analyses were made using the standard Bulletin 17B (Interagency Committee on Water Data, 1981) log-Pearson type III (B17B) methods as implemented in PeakFQ (Flynn and others, 2006) and by the expected moments algorithm (EMA) for 20-, 10-, 4-, 2-, 1-, 0.5-, and 0.2-percent AEP floods. The B17B and EMA methods use the same statistical moments (mean, standard deviation, and skew) of the logs of the annual peak flows to fit the data to a log-Pearson type III probability distribution. The difference is that the $\mathrm{B} 17 \mathrm{~B}$ method fits the data point values, whereas the EMA method uses point and interval data to better utilize available information. The inverse of the AEP is an approximation of the recurrence interval of a flood, which for the AEPs listed are 5-, 10-, 25-, 50-, 100-, 200-, and 500-year return intervals, respectively.

The at-site AEP flood magnitudes were computed using a weighted skew determined from the average skews at 40 streamgages. Annual peak flow records were extended at 22 of the 40 streamgages using the maintenance of variance extension (MOVE) procedure to best represent the generalized skew for the region by incorporating the largest number of streamgages and longest period possible. After adjustments for low outliers, historic data, and uncertainties in the annual peak flows, an average skew of 0.52 was determined for the region with a root mean square error of 0.46 . At 18 long-term streamgages used in the skew analysis, high outliers were detected (annual peaks that far exceed other annual peaks) that were caused by four large independent events. Skews at these 18 streamgages averaged 0.93 and were 79 percent larger than the average skew determined from the 40 streamgages. It could be argued that because the high outliers are caused by independent events, the higher average skew values are more representative of the regional long-term population distribution. A change in the regional skew from 0.52 to 0.93 resulted in an average increase in the magnitude of 1- and 0.2-percent AEP floods by about 7 and 13 percent, respectively, but had progressively less effect on successively higher probability floods (more frequent floods).

Flood magnitudes were reported at selected AEPs at 43 streamgages, which included three additional streamgages in Rhode Island that were not used in the regional skew analysis because of regulation, an atypical large negative skew, and redundancy with a longer term downstream gage. In addition to flood flow estimates for selected AEPs, the magnitude of the 95-percent confidence interval was determined at each streamgage. The confidence interval determined by the EMA is considered more robust and a more accurate measure of the possible flood magnitudes for a given AEP than those determined by the standard $\mathrm{B} 17 \mathrm{~B}$ method. Regression equations to estimate magnitude of floods at selected AEPs at ungaged sites were developed from 41 of these streamgages; two of the three additional streamgages in Rhode Island were not used in the regional regression equation development because of regulation or redundancy.

Regional regression equations were developed to estimate magnitude of floods at selected AEPs at ungaged sites from atsite flood quantiles and their respective basin characteristics. A total of 55 basin characteristics were evaluated as potential explanatory variables in the regression; however, only three characteristics were statistically significant — drainage area (DA) in square miles, stream density (STRDEN) in miles per square mile, and basin storage (StorNHD) in percent. Stream density and storage were derived from the 1:24:000 National Hydrography Dataset (NHD). Storage is the total area of wetlands and water over the basin. All values used in the regression were transformed to base 10 logarithms. The final regression equations were developed using the USGS Weighted Multiple Linear Regression (WREG) program determined by the Generalized Least Squares (GLS) method, which is considered the most applicable for regional analysis because it accounts for streamgage record lengths and correlation between streamgages. The pseudo coefficient of determination (pseudo $\mathrm{R}^{2}$ ) indicates that the explanatory variables explain 95 to 96 percent of the variance in the flood magnitude from 20- to 0.2-percent AEPs at the 41 streamgages used to develop the regression equations. Flood flows at the 95-percent confidence level for each exceedance probability derived from the regional regression equation model error variance and the covariance matrix are also reported.

Flood flow estimates for a given AEP at gaged sites, particularly at sites with short records, can be improved by a weighted average of two independent estimates of the at-site analysis and the regional regression equations. The weighted estimate is based on the magnitude of the flood and uncertainty associated with each estimate. Differences between the magnitude of floods determined from the at-site estimate and the weighted estimate ranged from -44 to 28 percent; a positive value indicates the weighted estimate is greater than the at-site estimate, and conversely, a negative value indicates the weighted estimate is smaller than the at-site estimate. 
The progressive increase in difference with decreasing flood probability is attributed to the greater uncertainty of the flood magnitude as the exceedance probability decreases. Estimates of flood flows on a stream above or below a gaged location, within limits, also can be improved by combining the streamgage information with the regional regression equation. A weighting procedure is applicable when the ungaged to gaged drainage area ratio is between 0.5 and 1.5 and hydrologic characteristics of the basin do not abruptly change.

Effects of urbanization on flood flows also were examined because impervious cover is generally considered an important factor, and this region has a long history of urban development. The imperviousness of the streamgage basins used in the regression analysis ranged from 0.5 to 37 percent with a mean of 5.2 percent, and although imperviousness provided some explanatory power in the regression, it was not statistically significant at the 95-percent confidence level for any of the exceedance probabilities examined. Stratified datasets indicated a linear relation for 20-percent AEP floods that increase with increasing imperviousness, but only for basins underlain by 40 percent or more sand and gravel. The magnitude of the 20-percent AEP flood flow appears to be unrelated to imperviousness for basins underlain by less than 20 percent sand and gravel. For flood flows with lower AEPs, the relation between surficial deposits and imperviousness progressively weakened. This result is confirmed by analysis of three longterm streamgages in close proximity to each other with similar characteristics except for the percentage of imperviousness. Although regional flood studies in other areas of the country have found urbanization to be an important factor, results from this study indicate a complex interaction with other characteristics that confounds a statistical portrayal of urban effects on flood flows. Further research is needed in this area, particularly for small, highly developed basins where little data exist.

Standard methods for calculating the magnitude of floods for given exceedance probabilities are based on the assumption of stationarity, that is, annual peak flows exhibit no significant trend over time. A subset of 16 streamgages with 70 or more years of unregulated systematic record indicates all but 4 have a statistically significant positive trend at the 95-percent confidence level; three streamgages had a significant positive trend between the about 90- and 95-percent confidence level. The Theil slope of the 15 streamgages with statistical significance ranged from 3.2 to 28 percent with a median slope of 11 percent. If this trend continued linearly in time, then the magnitude of a flood with a given exceedance probability, on average, would be 6,13 , and 21 percent greater in 10,20, and 30 years, respectively. Trends and their effects can only be ascertained by continued monitoring of streamflow and the continued development of the science of nonstationarity in flood frequency analysis.

One of the purposes of updating the flood frequency information for Rhode Island was to assess the AEP of the 2010 flood. Of the 21 active streamgages in Rhode Island in 2010, 18 set new record peaks with AEPs ranging from 2 and 0.2 percent (50- to 500 -year return interval, respectively).
Most 2010 peak flows were between a 0.5- and 0.2-percent AEP except for streamgages in the Blackstone River Basin, which ranged between a 4- and 2-percent AEP.

\section{Acknowledgments}

The authors gratefully acknowledge Timothy A. Cohn and Julie E. Kiang of the U.S. Geological Survey (USGS) for their valuable assistance and guidance through the labyrinth of statistical procedures used in flood frequency analysis and regionalization. The authors also acknowledge Charles E. Berenbrock of the USGS for his assistance with the weighted independent estimates program.

\section{Selected References}

Alexander, T.W., and Wilson, G.L., 1995, Technique for estimating the 2- to 500-year flood discharges on unregulated streams in rural Missouri: U.S. Geological Survey WaterResources Investigations Report 95-4231, 33 p.

Benson, M.A., 1962, Factors influencing the occurrence of floods in a humid region of diverse terrain: U.S. Geological Survey Water-Supply Paper 1580-B, 30 p.

Bogart, D.B., 1960, Floods of August-October 1955, New England to North Carolina: U.S. Geological Survey WaterSupply Paper 1420, $854 \mathrm{p}$.

Cohn, T.A., Berenbrock, Charles, Kiang, J.E., and Mason, R.R., Jr., 2012, Calculating weighted estimates of peak streamflow statistics: U.S. Geological Survey Fact Sheet 2012-3038, 4 p., at http://pubs.usgs.gov/fs/2012/3038/.

Cohn, T.A., Lane, W.M., and Baier, W.G., 1997, An algorithm for computing moments-based flood quantile estimates when historical flood information is available: Water Resources Research, v. 33, no. 9, p. 2089-2096.

Cohn, T.A., Lane, W.M., and Stedinger, J.R., 2001, Confidence intervals for expected moments algorithm flood quantile estimates: Water Resources Research, v. 37, no. 6, p. 1695-1706.

Collins, M.J., 2009, Evidence for changing flood risk in New England since the late 20th century: Journal of the American Water Resources Association, v. 45, no. 2, p. 279-290.

Denny, C.S., 1982, Geomorphology of New England: U.S. Geological Survey Professional Paper 1208, 18 p.

Driver, N.E., and Tasker, G.D., 1990, Techniques for estimating storm-runoff loads, volumes, and selected constituent concentrations in urban watersheds in the United States: U.S. Geological Survey Water-Supply Paper 2362, 51 p. 
Eng, Ken, Chen, Yin-Yu, and Kiang, J.E., 2009, User's guide to the weighted-multiple-linear-regression program (WREG version 1.0): U.S. Geological Survey Techniques and Methods, book 4, chap. A8, 21 p., at http://pubs.usgs.gov/ $\mathrm{tm} / \mathrm{tm} 4 \mathrm{a} 8 /$.

Federal Emergency Management Agency, 1981, Flood insurance study, City of Warwick, Rhode Island, Kent County, September 15, 1981: Federal Emergency Management Agency community no. 445409, 16 p., 2 pls.

Flynn, K.M., Kirby, W.H., and Hummel, P.R., 2006, User's manual for PeakFQ, annual flood frequency analysis using bulletin 17B guidelines: U.S. Geological Survey Techniques and Methods Report, book 4, chap. B4, 42 p., at http://pubs.usgs.gov/tm/2006/tm4b4/.

Gotvald, A.J., Feaster, T.D., and Weaver, J.C., 2009, Magnitude and frequency of rural floods in the southeastern United States, 2006-Volume 1, Georgia: U.S. Geological Survey Scientific Investigations Report 2009-5043, 120 p., at http://pubs.usgs.gov/sir/2009/5043/.

Gotvald, A.J., and Knaak, A.E., 2011, Magnitude and frequency of floods for urban and small rural streams in Georgia, 2008: U.S. Geological Survey Scientific Investigations Report 2011-5042, 39 p., at http://pubs.usgs.gov/ $\operatorname{sir} / 2011 / 5042 /$.

Green, A.R., 1964, Magnitude and frequency of floods in the United States-Part 1A, North Atlantic slope basins, Maine to Connecticut: U.S. Geological Survey Water-Supply Paper $1671,260 \mathrm{p}$

Griffis, V.W., and Stedinger, J.R., 2007, The use of GLS regression in regional hydrologic analyses: Journal of Hydrology, v. 344, p. 82-95.

Griffis, V.W., and Stedinger, J.R., 2009, Log-Pearson Type 3 distribution and its application in flood frequency analysis. III-Sample skew and weighted skew estimators: Journal of Hydrologic Engineering, v. 14, no. 2, p. 121-130.

Griffis, V.W., Stedinger, J.R., and Cohn, T.A., 2004, Log Pearson Type 3 quantile estimators with regional skew information and low outlier adjustments: Water Resources Research, v. 40, W07503, 17 p.

Grover, N.C., 1937, The floods of March 1936-Part 1. New England rivers: U.S. Geological Survey Water-Supply Paper 798, 466 p.

Grubbs, F.E., and Beck, Glen, 1972, Extension of sample sizes and percentage points for significance tests of outlying observations: Technometrics, v. 14, no. 2, p. 847-854.
Gruber, A.M., Dirceu, S.R., Jr., and Stedinger, J.R., 2007, Models of regional skew based on Bayesian GLS regression, in Kabbes, K.C., ed., Proceedings of the World Environmental and Water Resources Congress 2007_Restoring our Natural Habitat, Tampa, Florida, May 15-19, 2007: Reston, Virginia, American Society of Civil Engineers, paper 40927-3285, $10 \mathrm{p}$.

Gruber, A.M., and Stedinger, J.R., 2008, Models of LP3 regional skew, data selection, and Bayesian GLS regression, in Babcock, R.W., Jr., and Walton, Raymond, eds., World Environmental and Water Resources Congress 2008Ahupua'a, Honolulu, Hawaii, May 12-16, 2008: Reston, Va., American Society of Civil Engineers, paper 596, 10 p.

Guimaraes, W.B., and Bohman, L.R., 1992, Techniques for estimating magnitude and frequency of floods in South Carolina, 1988: U.S. Geological Survey Water-Resources Investigations Report 91-4157, 175 p.

Hedgecock, T.S., and Feaster, T.D., 2007, Magnitude and frequency of floods in Alabama, 2003: U.S. Geological Survey Scientific Investigations Report 2007-5204, 28 p., at http://pubs.usgs.gov/sir/2007/5204/.

Hedgecock, T.S., and Lee, K.G., 2010, Magnitude and frequency of floods for urban streams in Alabama, 2007: U.S. Geological Survey Scientific Investigations Report 20105012, 17 p., at http://pubs.usgs.gov/sir/2010/5012/.

Helsel, D.R., and Hirsch, R.M., 2002, Statistical methods in water resources: U.S. Geological Survey Techniques of Water-Resources Investigations, book 4, chap. A3, 523 p.

Hirsch, R.M., 1982, A comparison of four streamflow record extension techniques: Water Resource Research, v. 18, no. 4, p. 1081-1088.

Hodgkins, G.A., and Dudley, R.W., 2005, Changes in the magnitude of annual and monthly streamflows in New England, 1902-2002: U.S. Geological Survey Scientific Investigations Report 2005-5135, 37 p., at http://pubs.usgs.gov/sir/2005/5135/.

Hollis, G.E., 1975, The effect of urbanization on floods of different recurrence interval: Water Resources Research, v. 11, no. 3 , p. $431-435$.

Huntington, T.G., Richardson, A.D., McGuire, K.J., and Hayhoe, Katharine, 2009, Climate and hydrological changes in the northeastern United States - Recent trends and implications for forested and aquatic ecosystems: Canadian Journal of Forest Research, v. 39, no. 2, p. 199-212.

Interagency Advisory Committee on Water Data, 1981, Guidelines for determining flood flow frequency: Bulletin 17B of the Hydrology Subcommittee, Office of Water Data Coordination, U.S. Geological Survey, Reston, Va., revised March 1982, 183 p. 
Jennings, M.E., Thomas, W.O., Jr., and Riggs, H.C., 1994, Nationwide summary of U.S. Geological Survey regional regression equations for estimating magnitude and frequency of floods for ungaged sites, 1993: U.S. Geological Survey Water-Resources Investigations Report 94-4002, 196 p. [Superseded by Water-Resources Investigations Report 02-4168.]

Johnson, C.G., and Laraway, G.A., 1977, Flood magnitude and frequency of small Rhode Island streams-Preliminary estimating relations: U.S. Geological Survey Open-File Report 76-883, 20 p.

Johnstone, Don, and Cross, W.P., 1949, Elements of applied hydrology: New York, N.Y., Ronald Press Co., 276 p.

Katz, R.W., Parlange, M.B., and Naveau, Philippe, 2002, Statistics of extremes in hydrology: Advances in Water Resources v. 25, p. 1287-1304.

Kinnison, H.B., 1930, The New England flood of November of 1927: U.S. Geological Survey Water-Supply Paper 636-C, $330 \mathrm{p}$.

Konrad, C.P., 2003, Effects of urban development on floods: U.S. Geological Survey Fact Sheet 076-03, 4 p.

Konrad, C.P., and Booth, D.B., 2002, Hydrologic trends associated with urban development for selected streams in the Puget Sound Basin, western Washington: U.S. Geological Survey Water-Resources Investigations Report 02-4040, 40 p., at http://pubs.usgs.gov/wri/wri024040/pdf/ WRIR02-4040.pdf.

Lins, H.F., and Slack, J.R., 2005, Seasonal and regional characteristics of U.S. streamflow trends in the United States from 1940 to 1999: Physical Geography, v. 26, no. 6, p. 489-501.

Ludwig, A.H., and Tasker, G.D., 1993, Regionalization of low-flow characteristics of Arkansas streams: U.S. Geological Survey Water-Resources Investigations Report 93-4013, $19 \mathrm{p}$.

Martin, G.R., Ruhl, K.J., Moore, B.L., and Rose, M.F., 1997, Estimation of peak discharge frequency of urban streams in Jefferson County, Kentucky: U.S. Geological Survey WaterResources Investigations Report 97-4219, 40 p.

Martins, E.S., and Stedinger, J.R., 2002, Cross-correlation among estimators of shape: Water Resources Research, v. 38, no. 11, 7 p., at http://www.agu.org/journals/wr/ wr0211/2002WR001589/2002WR001589.pdf.

McCabe, G.J., and Wolock, D.M., 2002, A step increase in streamflow in the conterminous United States: Geophysical Research Letters, v. 29, no. 24, p. 2185-2189, at http://www.agu.org/journals/gl/g10224/2002GL015999/ 2002GL015999.pdf.
Milly, P.C.D., Betancourt, Julio, Falkenmark, Malin, Hirsch, R.M., Kundzewicz, Z.W., Lettenmaier, D.P., and Stouffer, R.L., 2008, Stationarity is dead-Whither Water Management?: Science, v. 319, no. 5863, p. 573-574.

Moglen, G.E., and Shivers, D.E., 2006, Methods for adjusting U.S. Geological Survey rural regression peak discharges in urban settings: U.S. Geological Survey Scientific Investigations Report 2006-5270, 55 p., at http://pubs.usgs.gov/sir/2006/5270/.

Murphy, P.J., 2001a, Estimating equation for mixed populations of floods in Massachusetts: Journal of Hydrologic Engineering, v. 6, no. 1, p. 72-74.

Murphy, P.J., 2001b, Evaluation of mixed-population flood frequency analysis: Journal of Hydrologic Engineering, v. 6, no. 1 , p. 62-70.

National Oceanic and Atmospheric Administration, 2002, Rhode Island, sec. 37 of Monthly station normals of temperature, precipitation, and heating and cooling degree days 1971-2000: Climatography of the United States, no. 82, accessed March 3, 2012, at http://cdo.ncdc.noaa.gov/ climatenormals/clim81/RInorm.pdf.

National Oceanic and Atmospheric Administration, [undated], Historical hurricane tracks: National Oceanic and Atmospheric Administration, accessed May 4, 2012, at http://www.csc.noaa.gov/hurricanes/.

Ouarda, T.B.M.J., and El-Adlouni, S., 2011, Bayesian nonstationary frequency analysis of hydrological variables: Journal of the American Water Resources Association, v. 47, no. 3, p. 496-505.

Parker, G.W., Ries, K.G., III, and Socolow, R.S., 1998, The flood of June 1998 in Massachusetts and Rhode Island: U.S. Geological Survey Fact Sheet 110-98, 4 p., at http://pubs.usgs.gov/fs/fs110-98/.

Paulsen, C.G., Bigwood, B.L., Harrington, A.W., Hartwell, O.W., and Kinnison, H.B., 1940, Hurricane floods of September 1938: U.S. Geological Survey Water-Supply Paper 867, $562 \mathrm{p}$.

Perley, Sidney, 1891, Historic storms of New England: Salem, Mass., Salem Press, 341 p.

Reis, D.S., Jr., Stedinger, J.R., and Martins, E.S., 2005, Bayesian generalized least squares regression with application to log Pearson Type 3 regional skew estimation: Water Resources Research, v. 41, W10419, 14 p.

Ries, K.G., III, 2007, The National streamflow statistics program-A computer program for estimating streamflow statistics for ungaged sites: U.S. Geological Survey Techniques and Methods, book 4, chap. A6, 37 p., at http://pubs.usgs.gov/tm/2006/tm4a6/. 
Ries, K.G., III, and Atkins, J.B., 2002, The National flood frequency program, version 3-A computer program for estimating magnitude and frequency of floods for ungaged sites, 2002: U.S. Geological Survey WaterResources Investigations Report 02-4168, 42 p., at http://pubs.usgs.gov/wri/wri024168/.

Ries, K.G., III, and Crouse, M.Y., comps., 2002, The National Flood Frequency Program, version 3-A computer program for estimating magnitude and frequency of floods for ungaged sites, 2002: U.S. Geological Survey WaterResources Investigations Report 02-4168, 53 p., at http://pubs.usgs.gov/wri/wri024168/.

Ries, K.G., III, and Dillow, J.J.A., 2006, Magnitude and frequency of floods on nontidal streams in Delaware: U.S. Geological Survey Scientific Investigations Report 2006-5146, 59 p., at pubs.usgs.gov/sir/2006/5146/pdf/ sir2006-5146.pdf.

Ries, K.G., III, Guthrie, J.D., Rea, A.H., Steeves, P.A., and Stewart, D.W., 2008, StreamStats-A water resources web application: U.S. Geological Survey Fact Sheet 20083067, 6 p., at http://pubs.usgs.gov/fs/2008/3067/pdf/ fs-2008-3067-508.pdf.

Robbins, J.C., and Pope, B.F., III, 1996, Estimation of flood frequency characteristics of small urban streams in North Carolina: U.S. Geological Survey WaterResources Investigations Report 96-4084, 21 p., at http://pubs.usgs.gov/wri/1996/4084/report.pdf.

Sauer, V.B., 1974, Flood characteristics of Oklahoma streams-Techniques for calculating magnitude and frequency of floods in Oklahoma, with compilations of flood data through 1971: U.S. Geological Survey WaterResources Investigations Report 52-73, 301 p.

Sauer, V.B., Thomas, W.O., Stricker, V.A., and Wilson, K.V., 1983, Flood characteristics of urban watersheds in the United States: U.S. Geological Survey Water-Supply Paper 2207, 69 p.

Sherwood, J.M., 1994, Estimation of volume-durationfrequency relations of ungaged small urban streams in Ohio: Water Resources Bulletin, v. 30, no. 2, p. 261-269.

Small, David, Islam, Shafiqul, and Vogel, R.M., 2006, Trends in precipitation and streamflow in the eastern U.S.-Paradox or perception?: Geophysical Research Letters L03403, v. 33,4 p.

Southard, R.E., 2010, Estimation of the magnitude and frequency of floods in urban areas in Missouri: U.S. Geological Survey Scientific Investigations Report 2010-5073, 27 p., at http://pubs.usgs.gov/sir/2010/5073/.
Stamey, T.C., and Hess, G.W., 1993, Techniques for estimating magnitude and frequency of floods in rural basins of Georgia: U.S. Geological Survey Water-Resources Investigations Report 93-4016, 69 p.

Stedinger, J.R., and Tasker, G.D., 1985, Regional hydrologic analysis - 1 . Ordinary, weighted, and generalized least squares compared: Water Resources Research, v. 21, no. 9, p. 1421-1432.

Stedinger, J.R., and Tasker, G.D., 1986, Regional hydrologic analysis - 2. Model-error estimators, estimation of sigma and log-Pearson type 3 distributions: Water Resources Research, v. 22, no. 10, p. 1487-1499.

Tasker, G.D., and Stedinger, J.R., 1989, An operational GLS model for hydrologic regression: Journal of Hydrology, v. 111, p. 361-375.

Thomas, W.O., and Kirby, W.H., 2002, Estimation of extreme floods, in Ries, K.G., III, and Crouse, M.Y., eds., The National Flood Frequency Program, version 3-A computer program for estimating magnitude and frequency of floods for ungaged sites: U.S. Geological Survey WaterResources Investigations Report 02-4168, p. 12-14, at http://pubs.usgs.gov/wri/wri024168/.

Thomson, M.T., Cannon, W.B., Thomas, M.P., and Hayes, S.S., 1964, Historical floods in New England: U.S. Geological Survey Water-Supply Paper 1779-M, 105 p.

U.S. Army Corps of Engineers, 1958, Frequency of New England floods: U.S. Army Corps of Engineers Civil Works Investigations Project CW-151, $10 \mathrm{p}$.

U.S. Geological Survey, 2012, Peak streamflow for the Nation, in National Water Information System: U.S. Geological Survey, accessed May 4, 2012, at http://nwis.waterdata. usgs.gov/usa/nwis/peak/.

Verdi, R.J., and Dixon, J.F., 2011, Magnitude and frequency of floods for rural streams in Florida, 2006: U.S. Geological Survey Scientific Investigations Report 2011-5034, 69 p., 1 pl., at http://pubs.usgs.gov/sir/2011/5034/.

Villarini, Gabriele, Smith, J.A., Serinaldi, Francesco, Bales, Jerad, Bates, P.D., and Krajewski, W.F., 2009, Flood frequency analysis for nonstationary annual peak records in an urban drainage basin: Advances in Water Resources, v. 23, p. 1255-1266.

Walker, P.N., 1991, Rhode Island floods and droughts, with a section on General climatology, by R.E. Lautzenheiser, in National water summary 1988-89-Floods and droughts: U.S. Geological Survey Water-Supply Paper 2375, p. $483-488$. 
Walter, Meghan, and Vogel, R.M., 2010, Increasing trends in peak flows in the northeastern United States and their impacts on design, in Joint Federal Interagency Conference, 2d, Las Vegas, Nevada, June 27-July 1, 2010, Proceedings: Advisory Committee on Water Information, 16 p., at http://acwi.gov/sos/pubs/2ndJFIC/Contents/ 2F_Walter_03_01_10.pdf.

Watson, K.M., and Schopp, R.D., 2009, Methodology for estimation of flood magnitude and frequency for New Jersey streams: U.S. Geological Survey Scientific Investigations Report 2009-5167, 51 p., at http://pubs.usgs.gov/ sir/2009/5167/.

Wood, G.K., Swallow, L.A., Johnson, C.G., and Searles, G.H., 1970, Flood of March 1968 in eastern Massachusetts and Rhode Island: U.S. Geological Survey Open-File Report 70-373, $81 \mathrm{p}$. 


\section{Glossary}

adjusted r-squared (adj- $\mathbf{R}^{2}$ ) The adjusted coefficient of determination $\left(\operatorname{adj}-R^{2}\right)$, a measure of the percentage of the variation explained by the explanatory variables of the equation adjusted for the number of parameters in the equation.

annual exceedance probability (AEP)

The expected annual probability of a flood, previously referred to in terms of return period of a flood. The probability, often expressed as a decimal fraction less than 1.0 , that an annual peak discharge will be exceeded in a 1-year period. The reciprocal of the exceedance probability is referred to as the recurrence interval or return period in years.

annual peak The maximum instantaneous discharge occurring during a water year.

\section{average standard error of prediction}

The square root of the average spread or dispersion of the predicted value from the observed mean.

\section{average variance of prediction (AVP)}

The average spread or dispersion of the predicted value from the observed mean.

confidence interval The range of an estimated parameter value in which the true value lies for a specified probability (95-percent confidence level, $\alpha=5$ percent, is generally used throughout this report).

covariance A measure of how much two random variables change together. Positive values indicate variables tend to show similar behavior, whereas negative values indicate the greater value of one variable correspond to the smaller value of the other variable. In multiple variable regression, covariance is expressed in matrix form sized according to the number of variables in the regression.

expected moments algorithm (EMA) Method for fitting a probability distribution to annual peak discharge data using a generalized method of moments, similar to the standard log-Pearson type III (LPIII) method described in Bulletin 17B (Interagency Advisory Committee on Water Data, 1981), except the expected moments algorithm (EMA) can also use interval data, whereas LPIII is restricted to point data. Interval data provide additional information that cannot be represented by point data, such as the potential range of annual peak flows outside of the systematic and historic record and the uncertainties around recorded peaks used in the analysis.

generalized least squares (GLS)

A regression method that accounts for differences in the variances and cross correlations of the errors associated with different recorded discharges; known as GLS. Differences in variances can result from differences in the length of record for each site, whereas cross correlations among concurrent annual peak discharges results in cross correlation between estimated flood statistics, such as quantiles and skew coefficients.

historic flood Magnitude of a flood recorded, or estimated, outside the systematic period of record.

log-Pearson type III (LPIII) A frequency distribution determined from the statistical moments of the annual peak flow mean, standard deviation, and skew.

maintenance of variation extension (MOVE) A linear regression technique used for filling in missing streamflow data measurements or producing a unique extended streamflow sequence that maintains the mean and variance for the sample.

Mallow's $\boldsymbol{C}_{p}$ An estimate of the standardized mean square error of prediction; this is a compromise between maximizing the explained variance by including all relevant variables and minimizing the standard error by keeping the number of variables as small as possible.

mean square error (MSE) The average of the squares of the differences between the estimated values and the measured values. This metric represents how closely, on average, an estimated value matches a measured value. 
multicolinearity A statistical phenomenon in which two or more predictor variables in a multiple regression model are highly correlated, in which case the regression coefficients may change erratically in response to small changes in the model or the data.

ordinary least squares (OLS) Linear regression method is standard approach to the "least squares" solution of fitting and independent variable to one or more dependent variables.

outlier A data point that departs from the trend of the rest of a dataset as described by a distribution or other mathematical relationship.

100-year flood An annual peak discharge having an average recurrence interval of 100 years, corresponding to an annual exceedance probability of 1 percent.

predicted residual sum of squares (PRESS) A validation type estimator of error. Predicted residual sum of squares (PRESS) uses $n-1$ observations to develop the equation and then estimates the value of the observation that was left out. The process is repeated for each observation, and the prediction errors are squared and summed.

pseudo-R-squared (pseudo- $\boldsymbol{R}^{2}$ ) A statistic generated by GLS regression, the pseudo coefficient of determination (pseudo- $R^{2}$ ) is similar to the adj- $R^{2}$ in that it is a measure of the predictive strength of the regression model except that it removes the time sampling error.

root mean square error (RMSE)

The square root of the sum of the squares of the differences between estimated and the measured values divided by the number of observations minus one. This metric represents the magnitude of the differences between the estimated and measured values. Of particular concern in this report is the root mean square error (RMSE) of the regional skew estimate.

skew $(\gamma)$ A statistical measure of the data symmetry or lack thereof used to compute the flood frequency distribution. The skew generally is computed from the logarithms of annual peak discharges at the streamgage.
Because the skew is sensitive to outliers, it may be an unreliable estimate of the true skew, especially for small samples; Bulletin 17B (Interagency Committee on Water Data, 1981) recommends that the skew is weighted with a regional, or generalized, skew that is based on data from many longterm streamgages to produce at-site flood frequency estimates.

standard error of estimate (SE) Also referred to as the root mean squared error of the residuals, it is the standard deviation of observed values about the regression line. It is computed by dividing the unexplained variation or the error sum of squares by its degrees of freedom. In this study, the standard error is based on one standard deviation.

variance A measure of the spread or dispersion of a set of values around their mean calculated by the mean of the squares of the deviation of the value from the mean, which is equal to the square of the standard deviation.

variance inflation factor (VIF) Expresses the ratio of the actual variance of the coefficient of the explanatory variable to its variance if it were independent of the explanatory variables. A variance inflation factor greater than 5 to 10 generally indicates multicolinearity, a serious problem in the regression models.

variance of prediction (VP) A measure of the likely difference between the prediction provided by a regression model and the actual value of the variable.

weighted independent estimator (WIE) A software program that weights two independent estimates inversely proportional to the uncertainty of the individual estimates.

weighted least squares (WLS) A regression method that accounts for the variation in the errors caused by unequal record lengths at streamgages used to estimate the flood characteristics of interest. Weighted least squares regression incorporates weights associated with each data point into the fitting criterion. The size of the weights corresponds to the precision of the information contained in the record. 
Tables 7, 13, and 15 
Table 7. Estimated magnitude of flood flows and confidence limits for selected annual exceedance probabilities at selected streamgages in Rhode Island, Connecticut, and Massachusetts for the period of record through 2010.

[AEP, annual exceedance probability, in percent. Period of record analysis, the systematic record and historic peaks if present. Extended record analysis, includes the period of record plus records estimated by maintenance of variance extension (MOVE). Length of record used in the analysis is shown below each streamgage. B17B, flood frequency analysis made using Bulletin 17B (Interagency Committee on Water Data, 1981) guidelines. EMA, expected moments algorithm; the EMA analysis is for the period of record for stations were the record is not extended. Values in bold typeface are values used in the regional analysis. All values are in cubic feet per second $\left(\mathrm{ft}^{3} / \mathrm{s}\right)$. All values except for the systematic peak were computed from a weighted skew of 0.52 and root mean square error of $0.46 . \%$, percent; --, station record was not extended; RI, Rhode Island; MA, Massachusetts; CT, Connecticut]

\begin{tabular}{|c|c|c|c|c|c|c|c|c|c|c|c|}
\hline \multirow{4}{*}{$\begin{array}{l}\text { AEP } \\
(\%)\end{array}$} & \multirow{4}{*}{$\begin{array}{c}\text { Return } \\
\text { interval } \\
\text { (years) }\end{array}$} & \multirow{2}{*}{\multicolumn{3}{|c|}{$\begin{array}{c}\text { Period of record analysis } \\
\text { B17B }\end{array}$}} & \multirow{4}{*}{$\begin{array}{c}\text { Systematic } \\
\text { peak flow } \\
\text { estimate }\end{array}$} & \multicolumn{6}{|c|}{ Extended record analysis } \\
\hline & & & & & & \multicolumn{3}{|c|}{ B17B } & \multicolumn{3}{|c|}{ EMA } \\
\hline & & \multirow{2}{*}{$\begin{array}{l}\text { Peak flow } \\
\text { estimate }\end{array}$} & \multicolumn{2}{|c|}{ 95\% confidence } & & \multirow{2}{*}{$\begin{array}{l}\text { Peak flow } \\
\text { estimate }\end{array}$} & \multicolumn{2}{|c|}{ 95\% confidence } & \multirow{2}{*}{$\begin{array}{c}\text { Peak flow } \\
\text { estimate }\end{array}$} & \multicolumn{2}{|c|}{$95 \%$ confidence } \\
\hline & & & Lower & Upper & & & Lower & Upper & & Lower & Upper \\
\hline \multicolumn{12}{|c|}{ Rhode Island streamgages } \\
\hline \multicolumn{12}{|c|}{ Adamville Brook at Adamville, RI (01106000) } \\
\hline & & \multicolumn{10}{|c|}{ 1941-1978, 1987a } \\
\hline 20 & 5 & 220 & 200 & 250 & 220 & -- & -- & -- & 220 & 190 & 250 \\
\hline 10 & 10 & 260 & 230 & 300 & 250 & -- & -- & -- & 250 & 220 & 300 \\
\hline 4 & 25 & 310 & 270 & 370 & 290 & -- & -- & -- & 300 & 250 & 390 \\
\hline 2 & 50 & 340 & 290 & 420 & 310 & -- & -- & -- & 330 & 280 & 480 \\
\hline 1 & 100 & 380 & 320 & 470 & 330 & -- & -- & -- & 360 & 300 & 580 \\
\hline 0.5 & 200 & 410 & 340 & 520 & 340 & -- & -- & -- & 400 & 320 & 700 \\
\hline 0.2 & 500 & 450 & 380 & 590 & 360 & -- & -- & -- & 440 & 340 & 900 \\
\hline \multicolumn{12}{|c|}{${ }^{\mathrm{a} E M A}$ analysis detected and conditioned six low ouliers. } \\
\hline \multicolumn{12}{|c|}{ Beaver River near Usquepaug, RI (01117468) } \\
\hline & & \multicolumn{3}{|c|}{$1976-2010$} & \multicolumn{7}{|c|}{$1942-2010^{a, b}$} \\
\hline 20 & 5 & 230 & 190 & 290 & 230 & 190 & 170 & 210 & 190 & 160 & 230 \\
\hline 10 & 10 & 320 & 260 & 410 & 320 & 250 & 220 & 300 & 250 & 210 & 340 \\
\hline 4 & 25 & 460 & 360 & 650 & 470 & 350 & 300 & 430 & 350 & 280 & 580 \\
\hline 2 & 50 & 590 & 450 & 880 & 610 & 450 & 370 & 570 & 450 & 330 & 880 \\
\hline 1 & 100 & 750 & 550 & 1,200 & 790 & 560 & 460 & 740 & 560 & 400 & 1,320 \\
\hline 0.5 & 200 & 950 & 670 & 1,600 & 1,000 & 700 & 560 & 950 & 700 & 470 & 2,010 \\
\hline 0.2 & 500 & 1,300 & 850 & 2,240 & 1,370 & 930 & 710 & 1,310 & 920 & 570 & 3,500 \\
\hline \multicolumn{12}{|c|}{${ }^{a}$ Actual records 1942-1975 extended using Wood River at Hope Valley, RI (01118000). } \\
\hline \multicolumn{12}{|c|}{ Blackstone River at Woonsocket, RI (01112500) } \\
\hline & & & & & & 1929-20 & & & & & \\
\hline 20 & 5 & 9,160 & 8,290 & 10,300 & 9,180 & -- & -- & -- & 9,160 & 8,030 & 10,800 \\
\hline 10 & 10 & 11,800 & 10,500 & 13,600 & 11,800 & -- & -- & -- & 11,800 & 10,100 & 14,900 \\
\hline 4 & 25 & 15,800 & 13,800 & 18,800 & 15,700 & -- & -- & -- & 15,800 & 13,000 & 22,300 \\
\hline 2 & 50 & 19,300 & 16,400 & 23,500 & 19,100 & -- & -- & -- & 19,300 & 15,300 & 30,200 \\
\hline 1 & 100 & 23,100 & 19,400 & 28,900 & 22,800 & -- & -- & -- & 23,100 & 17,700 & 40,600 \\
\hline 0.5 & 200 & 27,500 & 22,700 & 35,100 & 27,100 & -- & -- & -- & 27,500 & 20,200 & 54,400 \\
\hline 0.2 & 500 & 34,200 & 27,500 & 44,900 & 33,400 & -- & -- & -- & 34,200 & 23,700 & 79,600 \\
\hline Branch R & at Fores & dale, RI (0111 & 1500) & & & & & & & & \\
\hline & & & & & 1940 & $2010(1936 \mathrm{H}$ & toric pe & & & & \\
\hline 20 & 5 & 2,890 & 2,560 & 3,320 & 2,830 & -- & -- & -- & 2,820 & 2,430 & 3,400 \\
\hline 10 & 10 & 3,800 & 3,310 & 4,490 & 3,670 & -- & -- & -- & 3,680 & 3,100 & 4,730 \\
\hline 4 & 25 & 5,160 & 4,380 & 6,330 & 4,880 & -- & -- & -- & 4,960 & 4,010 & 7,180 \\
\hline 2 & 50 & 6,320 & 5,260 & 7,980 & 5,880 & -- & -- & -- & 6,040 & 4,720 & 9,740 \\
\hline 1 & 100 & 7,630 & 6,230 & 9,900 & 6,990 & -- & -- & -- & 7,250 & 5,450 & 13,100 \\
\hline 0.5 & 200 & 9,100 & 7,290 & 12,100 & 8,200 & -- & -- & -- & 8,600 & 6,200 & 17,500 \\
\hline 0.2 & 500 & 11,300 & 8,860 & 15,600 & 9,990 & -- & -- & -- & 10,600 & 7,240 & 25,500 \\
\hline
\end{tabular}


Table 7. Estimated magnitude of flood flows and confidence limits for selected annual exceedance probabilities at selected streamgages in Rhode Island, Connecticut, and Massachusetts for the period of record through 2010.-Continued

\begin{tabular}{|c|c|c|c|c|c|c|c|c|c|c|c|}
\hline \multirow{4}{*}{$\begin{array}{l}\text { AEP } \\
(\%)\end{array}$} & \multirow{4}{*}{$\begin{array}{c}\text { Return } \\
\text { interval } \\
\text { (years) }\end{array}$} & \multirow{2}{*}{\multicolumn{3}{|c|}{$\begin{array}{c}\text { Period of record analysis } \\
\text { B17B }\end{array}$}} & \multirow{4}{*}{$\begin{array}{c}\text { Systematic } \\
\text { peak flow } \\
\text { estimate }\end{array}$} & \multicolumn{6}{|c|}{ Extended record analysis } \\
\hline & & & & & & \multirow{3}{*}{$\begin{array}{l}\text { Peak flow } \\
\text { estimate }\end{array}$} & \multicolumn{2}{|l|}{ B17B } & \multicolumn{3}{|c|}{ EMA } \\
\hline & & \multirow{2}{*}{$\begin{array}{l}\text { Peak flow } \\
\text { estimate }\end{array}$} & \multicolumn{2}{|c|}{ 95\% confidence } & & & \multicolumn{2}{|c|}{$95 \%$ confidence } & \multirow{2}{*}{$\begin{array}{l}\text { Peak flow } \\
\text { estimate }\end{array}$} & \multicolumn{2}{|c|}{ 95\% confidence } \\
\hline & & & Lower & Upper & & & Lower & Upper & & Lower & Upper \\
\hline \multicolumn{12}{|c|}{ Rhode Island streamgages-Continued } \\
\hline \multicolumn{12}{|c|}{ Chepachet River at Chepachet, RI (01111400) } \\
\hline & & \multicolumn{3}{|c|}{ 1965-1975 } & & & & $40-2010^{\mathrm{a}}$ & & & \\
\hline 20 & 5 & -- & -- & -- & 520 & 520 & 470 & 600 & 520 & 450 & 630 \\
\hline 10 & 10 & -- & -- & -- & 680 & 680 & 600 & 800 & 680 & 570 & 880 \\
\hline 4 & 25 & -- & -- & -- & 910 & 920 & 780 & 1,120 & 920 & 740 & 1,340 \\
\hline 2 & 50 & -- & -- & -- & 1,100 & 1,120 & 940 & 1,400 & 1,120 & 870 & 1,820 \\
\hline 1 & 100 & -- & -- & -- & 1,310 & 1,350 & 1,110 & 1,730 & 1,350 & 1,010 & 2,470 \\
\hline 0.5 & 200 & -- & -- & -- & 1,540 & 1,600 & 1,290 & 2,110 & 1,600 & 1,150 & 3,340 \\
\hline 0.2 & 500 & -- & -- & -- & 1,900 & 1,990 & 1,570 & 2,710 & 1,990 & 1,350 & 4,920 \\
\hline${ }^{2}$ Actual & ords $1965-75$ & extended usin & Branch Ri & at Forestd & , RI (01111500). & & & & & & \\
\hline Chipuxt & at $W E$ & Kingston, R & 01117350 & & & & & & & & \\
\hline & & & 974-2010 & & & & & $11-2010^{\mathrm{a}, \mathrm{b}}$ & & & \\
\hline 20 & 5 & 180 & 160 & 220 & 150 & 140 & 130 & 160 & 140 & 120 & 180 \\
\hline 10 & 10 & 250 & 210 & 320 & 200 & 190 & 170 & 230 & 190 & 160 & 270 \\
\hline 4 & 25 & 360 & 290 & 490 & 280 & 270 & 230 & 330 & 270 & 210 & 460 \\
\hline 2 & 50 & 460 & 360 & 670 & 360 & 350 & 290 & 440 & 350 & 260 & 700 \\
\hline 1 & 100 & 580 & 440 & 890 & 450 & 440 & 360 & 570 & 440 & 310 & 1,080 \\
\hline 0.5 & 200 & 730 & 530 & 1,170 & 560 & 550 & 430 & 740 & 550 & 360 & 1,660 \\
\hline 0.2 & 500 & 980 & 680 & 1,670 & 750 & 730 & 560 & 1,030 & 730 & 450 & 2,980 \\
\hline $\begin{array}{l}{ }^{2} \text { Actual } \\
\text { bError o }\end{array}$ & $\begin{array}{l}\text { ords 1974-2C } \\
\% \text { assigned }\end{array}$ & $\begin{array}{l}10 \text { extended us } \\
\text { to } 1968 \text { and } 19\end{array}$ & $\begin{array}{l}\text { ng Hunt Ri } \\
\text { O peaks for }\end{array}$ & at East $\mathrm{Gr}$ & nwich, RI (01117 & & & & & & \\
\hline Hunt Riv & eear East G & reenwich, $R$ & 01117000 & & & & & & & & \\
\hline & & & & & & $1941-20$ & & & & & \\
\hline 20 & 5 & 610 & 550 & 690 & 610 & -- & -- & -- & 610 & 530 & 750 \\
\hline 10 & 10 & 810 & 710 & 940 & 810 & -- & -- & -- & 810 & 680 & 1,080 \\
\hline 4 & 25 & 1,110 & 957 & 1,350 & 1,140 & -- & -- & -- & 1,110 & 880 & 1,780 \\
\hline 2 & 50 & 1,390 & 1,170 & 1,740 & 1,450 & -- & -- & -- & 1,390 & 1,060 & 2,610 \\
\hline 1 & 100 & 1,720 & 1,420 & 2,220 & 1,820 & -- & -- & -- & 1,720 & 1,240 & 3,850 \\
\hline 0.5 & 200 & 2,120 & 1,700 & 2,810 & 2,280 & -- & -- & -- & 2,120 & 1,450 & 5,710 \\
\hline 0.2 & 500 & 2,750 & 2,140 & 3,800 & 3,040 & -- & -- & -- & 2,750 & 1,750 & 9,620 \\
\hline a Set hig & reshold $(1,7$ & $8 \mathrm{ft}^{3} / \mathrm{s}$ ) to refle & that 1938 & k was larg & out less than 201 & eak $\left(2,380 \mathrm{ft}^{3}\right)$ &, $1938 \mathrm{stag}$ & only and & ects storm surg & & \\
\hline Mosha & $\mathrm{k}$ River at $\mathrm{P}$ & rovidence, $\mathrm{F}$ & 10111400 & & & & & & & & \\
\hline & & & 964-2010 & & & & & $42-2010^{\mathrm{a}}$ & & & \\
\hline 20 & 5 & 1,210 & 1,120 & 1,320 & 1,140 & 1,120 & 1,050 & 1,220 & 1,130 & 1,030 & 1,260 \\
\hline 10 & 10 & 1,400 & 1,290 & 1,560 & 1,320 & 1,320 & 1,220 & 1,450 & 1,320 & 1,190 & 1,540 \\
\hline 4 & 25 & 1,660 & 1,500 & 1,910 & 1,540 & 1,570 & 1,430 & 1,770 & 1,580 & 1,390 & 1,970 \\
\hline 2 & 50 & 1,870 & 1,660 & 2,190 & 1,690 & 1,770 & 1,590 & 2,030 & 1,770 & 1,530 & 2,360 \\
\hline 1 & 100 & 2,090 & 1,830 & 2,500 & 1,840 & 1,980 & 1,750 & 2,300 & 1,970 & 1,660 & 2,800 \\
\hline 0.5 & 200 & 2,320 & 2,000 & 2,820 & 1,990 & 2,190 & 1,920 & 2,590 & 2,180 & 1,790 & 3,320 \\
\hline 0.2 & 500 & 2,640 & 2,240 & 3,300 & 2,180 & 2,490 & 2,150 & 3,000 & 2,460 & 1,960 & 4,130 \\
\hline actual & rds 1964-2 & 10 extended us & ng Woonas & atucket Riv & at Centerdale, $\mathrm{R}$ & (01114500). & & & & & \\
\hline 4 & 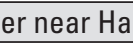 & ille, RI & 111300) & & & & & & & & \\
\hline & & & 965-2010 & & & & & $10-2010^{\mathrm{a}, \mathrm{b}}$ & & & \\
\hline 20 & 5 & 880 & 740 & 1,100 & 730 & 730 & 640 & 850 & 730 & 620 & 900 \\
\hline 10 & 10 & 1,200 & 980 & 1,520 & 980 & 990 & 850 & 1,180 & 990 & 810 & 1,310 \\
\hline 4 & 25 & 1,640 & 1,300 & 2,210 & 1,360 & 1,380 & 1,150 & 1,720 & 1,380 & 1,080 & 2,100 \\
\hline 2 & 50 & 2,020 & 1,570 & 2,840 & 1,680 & 1,720 & 1,410 & 2,220 & 1,720 & 1,300 & 2,980 \\
\hline 1 & 100 & 2,450 & 1,860 & 3,580 & 2,050 & 2,120 & 1,700 & 2,820 & 2,120 & 1,530 & 4,190 \\
\hline 0.5 & 200 & 2,930 & 2,170 & 4,430 & 2,470 & 2,580 & 2,020 & 3,530 & 2,580 & 1,780 & 5,850 \\
\hline 0.2 & 500 & 3,650 & 2,630 & 5,760 & 3,100 & 3,290 & 2,510 & 4,660 & 3,280 & 2,120 & 9,020 \\
\hline
\end{tabular}


Table 7. Estimated magnitude of flood flows and confidence limits for selected annual exceedance probabilities at selected streamgages in Rhode Island, Connecticut, and Massachusetts for the period of record through 2010.-Continued

\begin{tabular}{|c|c|c|c|c|c|c|c|c|c|c|c|}
\hline \multirow{4}{*}{$\begin{array}{l}\text { AEP } \\
(\%)\end{array}$} & \multirow{4}{*}{$\begin{array}{l}\text { Return } \\
\text { interval } \\
\text { (years) }\end{array}$} & \multirow{2}{*}{\multicolumn{3}{|c|}{$\begin{array}{c}\text { Period of record analysis } \\
\text { B17B }\end{array}$}} & \multirow{4}{*}{$\begin{array}{c}\text { Systematic } \\
\text { peak flow } \\
\text { estimate }\end{array}$} & \multicolumn{6}{|c|}{ Extended record analysis } \\
\hline & & & & & & \multirow{3}{*}{$\begin{array}{l}\text { Peak flow } \\
\text { estimate }\end{array}$} & \multicolumn{2}{|l|}{ B17B } & \multicolumn{3}{|c|}{ EMA } \\
\hline & & \multirow{2}{*}{$\begin{array}{l}\text { Peak flow } \\
\text { estimate }\end{array}$} & \multicolumn{2}{|c|}{ 95\% confidence } & & & \multicolumn{2}{|c|}{$95 \%$ confidence } & \multirow{2}{*}{$\begin{array}{l}\text { Peak flow } \\
\text { estimate }\end{array}$} & \multicolumn{2}{|c|}{$95 \%$ confidence } \\
\hline & & & Lower & Upper & & & Lower & Upper & & Lower & Upper \\
\hline \multicolumn{12}{|c|}{ Rhode Island streamgages-Continued } \\
\hline \multicolumn{12}{|c|}{ Nooseneck River at Nooseneck, RI (01115630) } \\
\hline & & \multicolumn{3}{|c|}{ 1965-1975 } & \multicolumn{7}{|c|}{$1942-2010^{a, b}$} \\
\hline 20 & 5 & 430 & 340 & 590 & 330 & 330 & 290 & 370 & 330 & 280 & 400 \\
\hline 10 & 10 & 600 & 450 & 880 & 430 & 430 & 380 & 500 & 430 & 360 & 560 \\
\hline 4 & 25 & 860 & 620 & 1,400 & 580 & 580 & 500 & 710 & 580 & 470 & 890 \\
\hline 2 & 50 & 1,100 & 760 & 1,930 & 720 & 720 & 600 & 910 & 720 & 550 & 1,260 \\
\hline 1 & 100 & 1,380 & 920 & 2,600 & 880 & 880 & 720 & 1,140 & 880 & 650 & 1,780 \\
\hline 0.5 & 200 & 1,710 & 1,100 & 3,450 & 1,070 & 1,060 & 850 & 1,420 & 1,060 & 750 & 2,500 \\
\hline 0.2 & 500 & 2,240 & 1,380 & 4,920 & 1,350 & 1,350 & 1,050 & 1,860 & 1,350 & 890 & 3,930 \\
\hline \multicolumn{12}{|c|}{$\begin{array}{l}\left.{ }^{a} \text { Actual record } 1965-75 \text { extended using Wood River at Hope Valley, RI ( } 01118000\right) \text {. } \\
{ }^{b} \text { Error of } \pm 16 \% \text { assigned to } 1982 \text { peak. }\end{array}$} \\
\hline \multicolumn{12}{|c|}{ Pawtuxet River at Cranston, RI (01116500) } \\
\hline & & \multicolumn{10}{|c|}{$1940-2010^{\mathrm{a}}$} \\
\hline 20 & 5 & 2,830 & 2,570 & 3,170 & 2,830 & -- & -- & -- & 2,900 & 2,400 & 3,420 \\
\hline 10 & 10 & 3,740 & 3,330 & 4,300 & 3,740 & -- & -- & -- & 3,840 & 3,220 & 4,840 \\
\hline 4 & 25 & 5,230 & 4,520 & 6,290 & 5,230 & -- & -- & -- & 5,420 & 4,330 & 8,340 \\
\hline 2 & 50 & 6,640 & 5,600 & 8,260 & 6,640 & -- & -- & -- & 6,940 & 5,290 & 14,100 \\
\hline 1 & 100 & 8,370 & 6,880 & 10,800 & 8,370 & -- & -- & -- & 8,820 & 6,370 & 24,000 \\
\hline 0.5 & 200 & 10,500 & 8,400 & 13,900 & 10,500 & -- & -- & -- & 11,100 & 7,590 & 38,200 \\
\hline 0.2 & 500 & 14,000 & 10,800 & 19,400 & 14,000 & -- & -- & -- & 15,000 & 9,450 & 70,700 \\
\hline
\end{tabular}

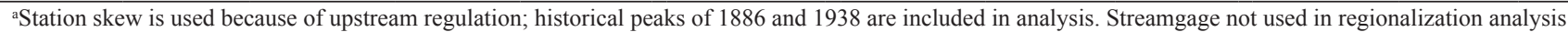
because of upstream regulation by Scituate Reservoir.

Pawcatuck River at Westerly, RI (01118500)

\begin{tabular}{|c|c|c|c|c|c|c|c|c|c|c|c|}
\hline \multirow[b]{2}{*}{20} & \multirow[b]{2}{*}{5} & \multicolumn{10}{|c|}{ 1941-2010 (Historical peaks 1927 and 1936 } \\
\hline & & 3,300 & 3,040 & 3,620 & 3,310 & -- & -- & -- & 3,400 & 3,030 & 3,940 \\
\hline 10 & 10 & 4,080 & 3,710 & 4,570 & 4,160 & -- & -- & -- & 4,230 & 3,680 & 5,200 \\
\hline 4 & 25 & 5,230 & 4,650 & 6,060 & 5,480 & -- & -- & -- & 5,460 & 4,560 & 7,550 \\
\hline 1 & 100 & 7,340 & 6,310 & 8,930 & 8,070 & -- & -- & -- & 7,730 & 6,000 & 13,500 \\
\hline 0.5 & 200 & 8,610 & 7,270 & 10,700 & 9,700 & -- & -- & -- & 9,100 & 6,790 & 18,100 \\
\hline 0.2 & 500 & 10,600 & 8,700 & 13,600 & 12,300 & -- & -- & -- & 11,200 & 7,910 & 26,700 \\
\hline
\end{tabular}

${ }^{a}$ Set high threshold $\left(7,625 \mathrm{ft}^{3} / \mathrm{s}\right)$ above 1936 historical peak $\left(3,150 \mathrm{ft}^{3} / \mathrm{s}\right)$ to reflect that 1938 peak was likely larger.

Pawcatuck River at Wood River Junction, RI (01117500)

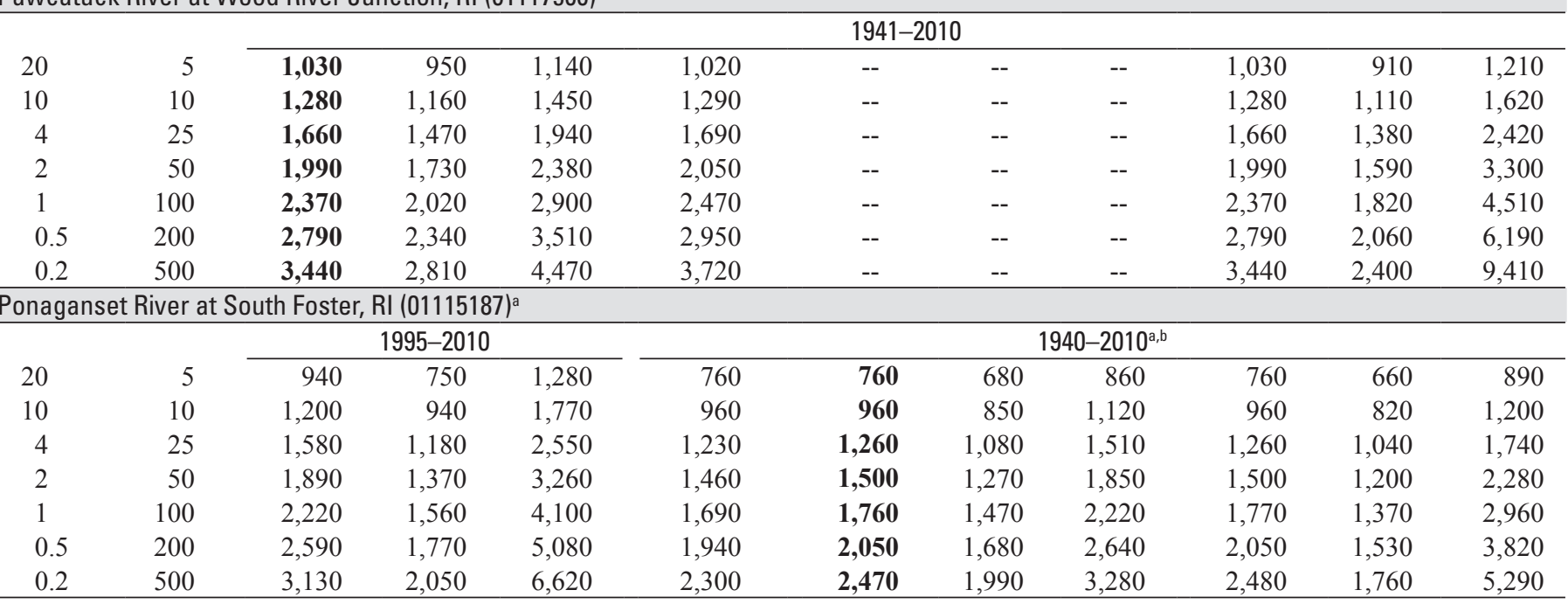

${ }^{\mathrm{a}}$ Actual records 1995-2010 extended using Branch River at Forestdale, RI (01111500).

${ }^{\mathrm{b}}$ Error of $\pm 5 \%$ assigned to $1955,1968,1979$, and 1982 peak for EMA analysis. 
Table 7. Estimated magnitude of flood flows and confidence limits for selected annual exceedance probabilities at selected streamgages in Rhode Island, Connecticut, and Massachusetts for the period of record through 2010.-Continued

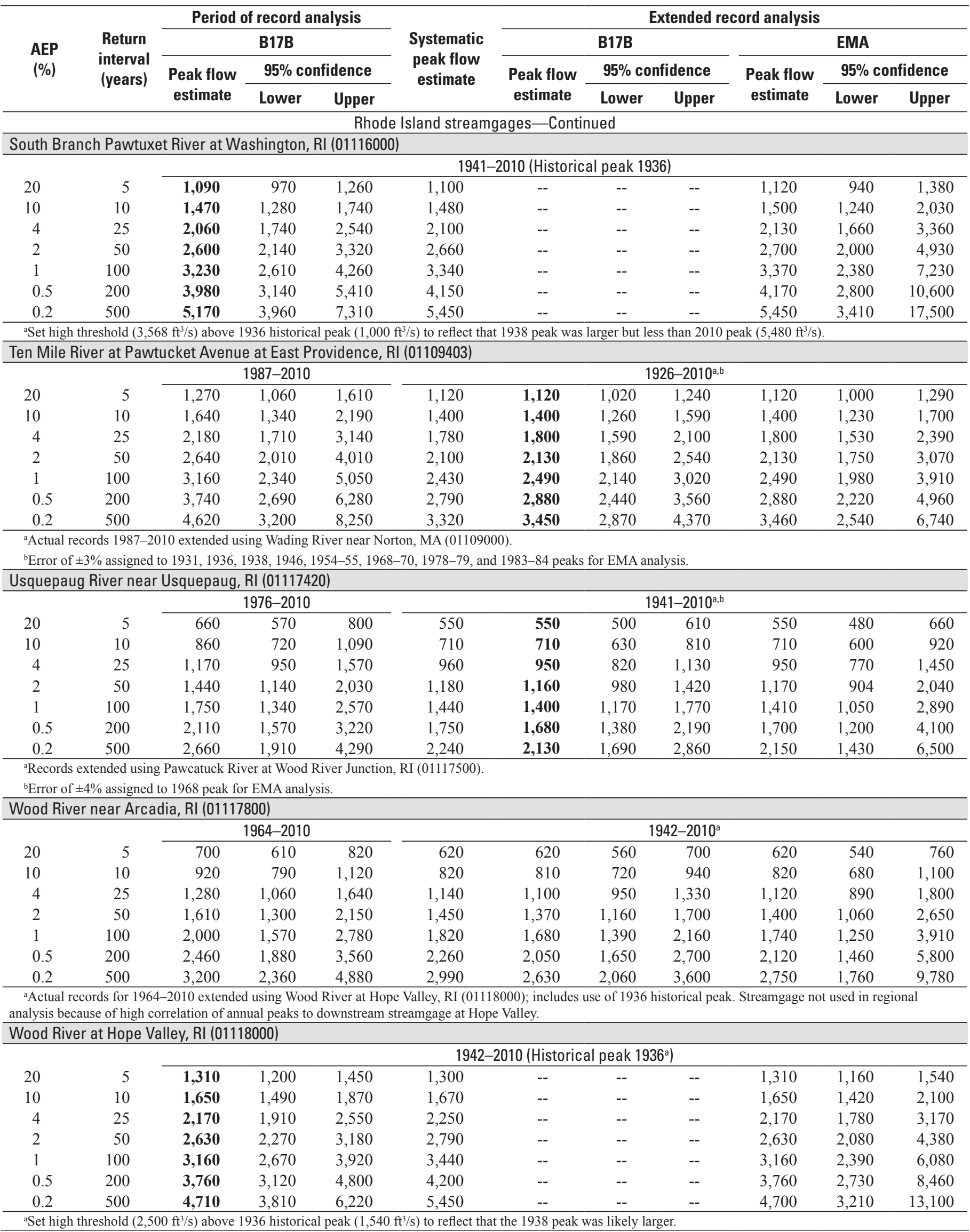


Table 7. Estimated magnitude of flood flows and confidence limits for selected annual exceedance probabilities at selected streamgages in Rhode Island, Connecticut, and Massachusetts for the period of record through 2010.-Continued

\begin{tabular}{|c|c|c|c|c|c|c|c|c|c|c|c|}
\hline \multirow{3}{*}{$\begin{array}{l}\text { AEP } \\
(\%)\end{array}$} & \multirow{3}{*}{$\begin{array}{c}\text { Return } \\
\text { interval } \\
\text { (years) }\end{array}$} & \multirow{2}{*}{\multicolumn{3}{|c|}{$\begin{array}{c}\text { Period of record analysis } \\
\text { B17B } \\
\end{array}$}} & \multirow{3}{*}{$\begin{array}{c}\text { Systematic } \\
\text { peak flow } \\
\text { estimate }\end{array}$} & \multicolumn{6}{|c|}{ Extended record analysis } \\
\hline & & & & & & \multicolumn{3}{|c|}{ B17B } & \multicolumn{3}{|c|}{ EMA } \\
\hline & & $\begin{array}{l}\text { Peak flow } \\
\text { estimate }\end{array}$ & \multicolumn{2}{|c|}{ 95\% confidence } & & $\begin{array}{l}\text { Peak flow } \\
\text { estimate }\end{array}$ & \multicolumn{2}{|c|}{ 95\% confidence } & $\begin{array}{l}\text { Peak flow } \\
\text { estimate }\end{array}$ & \multicolumn{2}{|c|}{ 95\% confidence } \\
\hline \multicolumn{12}{|c|}{ Rhode Island streamgages-Continued } \\
\hline \multicolumn{12}{|c|}{ Woonasquatucket River at Centerdale, RI (01114500) } \\
\hline & & \multicolumn{10}{|c|}{ 1942-2010 (Historical peak 1936ª) } \\
\hline 10 & 10 & 1,150 & 1,020 & 1,340 & 1,150 & -- & -- & -- & 1,150 & 990 & 1,400 \\
\hline 4 & 25 & 1,470 & 1,270 & 1,760 & 1,440 & -- & -- & -- & 1,460 & 1,230 & 1,940 \\
\hline 2 & 50 & 1,720 & 1,460 & 2,110 & 1,670 & -- & -- & -- & 1,720 & 1,400 & 2,450 \\
\hline 1 & 100 & 1,990 & 1,670 & 2,490 & 1,900 & -- & -- & -- & 1,980 & 1,570 & 3,070 \\
\hline 0.5 & 200 & 2,270 & 1,880 & 2,900 & 2,130 & -- & -- & -- & 2,270 & 1,740 & 3,810 \\
\hline 0.2 & 500 & 2,670 & 2,170 & 3,500 & 2,460 & -- & -- & -- & 2,670 & 1,960 & 5,020 \\
\hline 20 & 5 & 730 & 610 & 900 & 720 & -- & -- & -- & 730 & 570 & 1,000 \\
\hline 10 & 10 & 1,080 & 880 & 1,400 & 1,080 & -- & -- & -- & 1,080 & 810 & 1,740 \\
\hline 4 & 25 & 1,720 & 1,330 & 2,380 & 1,730 & -- & -- & -- & 1,720 & 1,190 & 3,580 \\
\hline 2 & 50 & 2,350 & 1,760 & 3,430 & 2,390 & -- & -- & -- & 2,350 & 1,540 & 6,230 \\
\hline 1 & 100 & 3,170 & 2,300 & 4,850 & 3,230 & -- & -- & -- & 3,170 & 1,930 & 10,900 \\
\hline 0.5 & 200 & 4,200 & 2,940 & 6,760 & 4,320 & -- & -- & -- & 4,200 & 2,380 & 19,000 \\
\hline 0.2 & 500 & 6,000 & 4,020 & 10,300 & 6,230 & -- & -- & -- & 6,000 & 3,070 & 39,800 \\
\hline Little Ri & ar Oxfor & MA 1011245 & & & & & & & & & \\
\hline & & & $940-1958$ & & & & & $13-2010^{a}$ & & & \\
\hline 20 & 5 & 830 & 600 & 1,300 & 670 & 700 & 630 & 800 & 700 & 600 & 870 \\
\hline 10 & 10 & 1,340 & 920 & 2,370 & 1,010 & 1,010 & 890 & 1,180 & 1,010 & 820 & 1,400 \\
\hline Mumforc & $\mathrm{cot}_{\mathrm{C}} \mathrm{cot}$ & ouglas, MA & 0111100 & & & & & & & & \\
\hline & & 1939-195 & $1,1955,2$ & 4-2010 & & & & $40-2010$ & & & \\
\hline 20 & 5 & 680 & 510 & 1,000 & 700 & 690 & 600 & 810 & 690 & 580 & 870 \\
\hline 10 & 10 & 1,000 & 720 & 1,640 & 960 & 960 & 820 & 1,170 & 960 & 780 & 1,320 \\
\hline 4 & 25 & 1,570 & 1,060 & 2,980 & 1,380 & 1,390 & 1,150 & 1,770 & 1,390 & 1,070 & 2,250 \\
\hline 2 & 50 & 2,140 & 1,360 & 4,530 & 1,760 & 1,790 & 1,440 & 2,360 & 1,790 & 1,310 & 3,350 \\
\hline 1 & 100 & 2,880 & 1,730 & 6,760 & 2,210 & 2,260 & 1,780 & 3,080 & 2,260 & 1,570 & 4,950 \\
\hline 0.5 & 200 & 3,810 & 2,170 & 9,930 & 2,740 & 2,820 & 2,160 & 3,960 & 2,820 & 1,860 & 7,270 \\
\hline 0.2 & 500 & 5,440 & 2,890 & 16,200 & 3,580 & 3,710 & 2,760 & 5,430 & 3,710 & 2,280 & 12,000 \\
\hline${ }^{\mathrm{a}}$ Actual & d 1939-51 & $2004-10$ exten & ed using $\mathrm{E}$ & nch River & restdale, RI & 1500). & & & & & \\
\hline Neponse & er at Nor & Nood, MA (0 & 105000) & & & & & & & & \\
\hline & & & & & & $1939-2$ & & & & & \\
\hline 20 & 5 & 600 & 540 & 670 & 600 & -- & -- & -- & 600 & 520 & 710 \\
\hline 10 & 10 & 770 & 680 & 890 & 770 & -- & -- & -- & 770 & 650 & 990 \\
\hline 4 & 25 & 1,020 & 890 & 1,220 & 1,020 & -- & -- & -- & 1,020 & 830 & 1,510 \\
\hline 2 & 50 & 1,240 & 1,060 & 1,520 & 1,240 & -- & -- & -- & 1,240 & 970 & 2,080 \\
\hline 1 & 100 & 1,490 & 1,240 & 1,870 & 1,490 & -- & -- & -- & 1,490 & 1,120 & 2,860 \\
\hline 0.5 & 200 & 1,770 & 1,450 & 2,280 & 1,770 & -- & -- & -- & 1,780 & 1,280 & 3,940 \\
\hline 0.2 & 500 & 2,200 & 1,760 & 2,930 & 2,200 & -- & -- & -- & 2,220 & 1,510 & 5,990 \\
\hline
\end{tabular}


Table 7. Estimated magnitude of flood flows and confidence limits for selected annual exceedance probabilities at selected streamgages in Rhode Island, Connecticut, and Massachusetts for the period of record through 2010.-Continued

\begin{tabular}{|c|c|c|c|c|c|c|c|c|c|c|c|}
\hline \multirow{4}{*}{$\begin{array}{l}\text { AEP } \\
(\%)\end{array}$} & \multirow{4}{*}{$\begin{array}{c}\text { Return } \\
\text { interval } \\
\text { (years) }\end{array}$} & \multirow{2}{*}{\multicolumn{3}{|c|}{$\begin{array}{c}\text { Period of record analysis } \\
\text { B17B }\end{array}$}} & \multirow{4}{*}{$\begin{array}{c}\text { Systematic } \\
\text { peak flow } \\
\text { estimate }\end{array}$} & \multicolumn{6}{|c|}{ Extended record analysis } \\
\hline & & & & & & \multirow{3}{*}{$\begin{array}{c}\text { Peak flow } \\
\text { estimate }\end{array}$} & \multicolumn{2}{|l|}{ B17B } & \multicolumn{3}{|c|}{ EMA } \\
\hline & & \multirow{2}{*}{$\begin{array}{l}\text { Peak flow } \\
\text { estimate }\end{array}$} & \multicolumn{2}{|c|}{$95 \%$ confidence } & & & \multicolumn{2}{|c|}{ 95\% confidence } & \multirow{2}{*}{$\begin{array}{l}\text { Peak flow } \\
\text { estimate }\end{array}$} & \multicolumn{2}{|c|}{ 95\% confidence } \\
\hline & & & Lower & Upper & & & Lower & Upper & & Lower & Upper \\
\hline \multicolumn{12}{|c|}{ Massachusetts streamgages_-Continued } \\
\hline \multicolumn{12}{|c|}{ Quaboag River at West Brimfield, MA (01176000) } \\
\hline & & & & & & $1913-20$ & & & & & \\
\hline 20 & 5 & 1,870 & 1,710 & 2,060 & 1,790 & -- & -- & -- & 1,870 & 1,640 & 2,210 \\
\hline 10 & 10 & 2,470 & 2,230 & 2,780 & 2,450 & -- & -- & -- & 2,470 & 2,110 & 3,170 \\
\hline 4 & 25 & 3,460 & 3,040 & 4,040 & 3,660 & -- & -- & -- & 3,460 & 2,790 & 5,210 \\
\hline 2 & 50 & 4,390 & 3,780 & 5,270 & 4,920 & -- & -- & -- & 4,390 & 3,370 & 7,640 \\
\hline 1 & 100 & $\mathbf{5 , 5 3 0}$ & 4,660 & 6,830 & 6,600 & -- & -- & -- & 5,530 & 4,030 & 11,300 \\
\hline 0.5 & 200 & 6,910 & 5,710 & 8,780 & 8,820 & -- & -- & -- & 6,910 & 4,770 & 16,700 \\
\hline 0.2 & 500 & 9,220 & 7,400 & 12,100 & 12,900 & -- & -- & -- & 9,220 & 5,890 & 28,200 \\
\hline Sevenm & iiver near & pencer, MA & 01175760 & & & & & & & & \\
\hline & & & 61-2010 & & & & & $3-2010^{\mathrm{a}, \mathrm{b}}$ & & & \\
\hline 20 & 5 & 290 & 250 & 340 & 280 & 300 & 260 & 330 & 300 & 250 & 370 \\
\hline 10 & 10 & 360 & 310 & 440 & 420 & 420 & 370 & 490 & 420 & 340 & 580 \\
\hline 4 & 25 & 470 & 390 & 580 & 690 & 650 & 550 & 790 & 650 & 490 & 1,100 \\
\hline 2 & 50 & 550 & 450 & 710 & 990 & 880 & 730 & 1,110 & 880 & 630 & 1,790 \\
\hline 1 & 100 & 640 & 520 & 840 & 1,400 & 1,180 & 940 & 1,540 & 1,180 & 790 & 2,930 \\
\hline 0.5 & 200 & 730 & 580 & 990 & 1,980 & 1,560 & 1,220 & 2,120 & 1,570 & 980 & 4,810 \\
\hline 0.2 & 500 & 860 & 680 & 1,200 & 3,110 & 2,240 & 1,690 & 3,180 & 2,260 & 1,280 & 9,340 \\
\hline${ }^{2}$ Actual & ords $1961-2$ & 10 extended us & g Quabo: & River at W & Brimfield, MA ( & 176000). & & & & & \\
\hline${ }^{\mathrm{b}}$ Error $\mathrm{C}$ & $\%$ assign & to 1936,1938 , & nd $1955 \mathrm{p}$ & ks for EM & lysis. & & & & & & \\
\hline aunton & neart & gewater, $\mathrm{M}$ & 1011080 & & & & & & & & \\
\hline & & 1931-76, & $5-89,96$ & $8-2010$ & & & & $6-2010^{\mathrm{a}, \mathrm{b}}$ & & & \\
\hline 20 & 5 & 3,200 & 2,980 & 3,470 & 3,210 & 3,160 & 2,970 & 3,400 & 3,150 & 2,910 & 3,460 \\
\hline 10 & 10 & 3,710 & 3,420 & 4,090 & 3,670 & 3,670 & 3,420 & 4,000 & 3,660 & 3,350 & 4,130 \\
\hline 4 & 25 & 4,350 & 3,960 & 4,900 & 4,210 & 4,320 & 3,960 & 4,790 & 4,300 & 3,860 & 5,120 \\
\hline 2 & 50 & 4,840 & 4,350 & 5,530 & 4,580 & 4,800 & 4,370 & 5,400 & 4,780 & 4,220 & 5,960 \\
\hline 1 & 100 & 5,320 & 4,740 & 6,180 & 4,930 & 5,290 & 4,770 & 6,020 & 5,260 & 4,550 & 6,880 \\
\hline 0.5 & 200 & 5,820 & 5,140 & 6,850 & 5,260 & 5,780 & 5,170 & 6,660 & 5,750 & 4,870 & 7,900 \\
\hline 0.2 & 500 & 6,500 & 5,660 & 7,770 & 5,680 & 6,450 & 5,700 & 7,540 & 6,410 & 5,270 & 9,430 \\
\hline $\begin{array}{l}{ }^{{ }^{\mathrm{a}} \text { Actual }} \\
{ }^{\mathrm{b}} \text { Error }\end{array}$ & ord 1931- & $\begin{array}{l}1985-89,1996 \\
\end{array}$ & 1998-201 & extended u & Vading River & ar Norton, MA & 01109000) & & & & \\
\hline Threemi & iver near I & Jorth Dighton & MA (011 & Ko60) & & & & & & & \\
\hline & & & $967-201$ & & & & & $6-2010^{a, b}$ & & & \\
\hline 20 & 5 & 1,640 & 1,440 & 1,930 & 1,430 & 1,420 & 1,300 & 1,580 & 1,420 & 1,270 & 1,630 \\
\hline 10 & 10 & 2,050 & 1,760 & 2,490 & 1,760 & 1,760 & 1,590 & 1,990 & 1,760 & 1,550 & 2,110 \\
\hline 4 & 25 & 2,600 & 2,180 & 3,280 & 2,200 & 2,230 & 1,980 & 2,590 & 2,240 & 1,910 & 2,890 \\
\hline 2 & 50 & 3,030 & 2,500 & 3,940 & 2,550 & 2,610 & 2,280 & 3,090 & 2,620 & 2,180 & 3,630 \\
\hline 1 & 100 & 3,490 & 2,820 & 4,640 & 2,920 & 3,010 & 2,600 & 3,630 & 3,020 & 2,440 & 4,530 \\
\hline 0.5 & 200 & 3,960 & 3,160 & 5,400 & 3,300 & 3,440 & 2,930 & 4,220 & 3,460 & 2,710 & 5,600 \\
\hline 0.2 & 500 & 4,620 & 3,610 & 6,500 & 3,840 & 4,060 & 3,400 & 5,080 & 4,080 & 3,060 & 7,360 \\
\hline $\begin{array}{l}{ }^{a} \text { Actual } \\
\text { bError }\end{array}$ & $\begin{array}{l}\text { ords } 1967- \\
2 \% \text { assigne }\end{array}$ & $\begin{array}{l}10 \text { extended us } \\
\text { o } 1931,1936\end{array}$ & $\begin{array}{l}\text { g Wading } \\
\text { d } 1955 \mathrm{pe}\end{array}$ & $\begin{array}{l}\text { iver near } \mathrm{I} \\
\text { s for EMA }\end{array}$ & $\begin{array}{l}\text { 1, MA (0110 } \\
\text { sis. }\end{array}$ & & & & & & \\
\hline Vading & near No & ton, MA (011 & 9000) & & & & & & & & \\
\hline & & & & & & $1926-$ & & & & & \\
\hline 20 & 5 & 720 & 660 & 790 & 720 & -- & -- & -- & 720 & 640 & 820 \\
\hline 10 & 10 & 900 & 810 & 1,010 & 890 & -- & -- & -- & 900 & 780 & 1,080 \\
\hline 4 & 25 & 1,150 & 1,020 & 1,330 & 1,140 & -- & -- & -- & 1,150 & 970 & 1,520 \\
\hline 2 & 50 & 1,360 & 1,180 & 1,610 & 1,330 & -- & -- & -- & 1,360 & 1,120 & 1,940 \\
\hline 1 & 100 & 1,580 & 1,360 & 1,910 & 1,540 & -- & -- & -- & 1,580 & 1,260 & 2,470 \\
\hline 0.5 & 200 & 1,830 & 1,550 & 2,250 & 1,770 & -- & -- & -- & 1,830 & 1,410 & 3,130 \\
\hline 0.2 & 500 & 2,180 & 1,820 & 2,760 & 2,100 & -- & -- & -- & 2,180 & 1,610 & 4,250 \\
\hline
\end{tabular}


Table 7. Estimated magnitude of flood flows and confidence limits for selected annual exceedance probabilities at selected streamgages in Rhode Island, Connecticut, and Massachusetts for the period of record through 2010.—Continued

\begin{tabular}{|c|c|c|c|c|c|c|c|c|c|c|c|}
\hline \multirow{3}{*}{$\begin{array}{l}\text { AEP } \\
(\%)\end{array}$} & \multirow{3}{*}{$\begin{array}{c}\text { Return } \\
\text { interval } \\
\text { (years) }\end{array}$} & \multirow{2}{*}{\multicolumn{3}{|c|}{$\begin{array}{c}\text { Period of record analysis } \\
\text { B17B }\end{array}$}} & \multirow{3}{*}{$\begin{array}{c}\text { Systematic } \\
\text { peak flow } \\
\text { estimate }\end{array}$} & \multicolumn{6}{|c|}{ Extended record analysis } \\
\hline & & & & & & \multicolumn{3}{|c|}{ B17B } & \multicolumn{3}{|c|}{ EMA } \\
\hline & & $\begin{array}{l}\text { Peak flow } \\
\text { estimate }\end{array}$ & \multicolumn{2}{|c|}{$95 \%$ confidence } & & $\begin{array}{l}\text { Peak flow } \\
\text { estimate }\end{array}$ & \multicolumn{2}{|c|}{ 95\% confidence } & $\begin{array}{l}\text { Peak flow } \\
\text { estimate }\end{array}$ & \multicolumn{2}{|c|}{ 95\% confidence } \\
\hline \multicolumn{12}{|c|}{ Connecticut streamgages } \\
\hline \multicolumn{12}{|c|}{ Blackwell Brook near Brooklyn, CT (01126600) } \\
\hline & & \multicolumn{3}{|c|}{$1962-1976$} & & & & $52-2010^{\mathrm{a}}$ & & & \\
\hline 10 & 10 & 1,270 & 900 & 2,160 & 1,240 & 1,260 & 1,060 & 1,540 & 1,260 & 1,030 & 1,660 \\
\hline 4 & 25 & 1,810 & 1,220 & 3,520 & 1,630 & 1,700 & 1,400 & 2,170 & 1,700 & 1,340 & 2,550 \\
\hline 2 & 50 & 2,300 & 1,480 & 4,890 & 1,940 & 2,070 & 1,670 & 2,720 & 2,070 & 1,580 & 3,460 \\
\hline 1 & 100 & 2,850 & 1,760 & 6,640 & 2,260 & 2,470 & 1,960 & 3,350 & 2,480 & 1,820 & 4,630 \\
\hline 0.5 & 200 & 3,490 & 2,070 & 8,830 & 2,600 & 2,920 & 2,270 & 4,050 & 2,920 & 2,060 & 6,140 \\
\hline 0.2 & 500 & 4,470 & 2,520 & 12,600 & 3,070 & 3,560 & 2,710 & 5,120 & 3,580 & 2,370 & 8,800 \\
\hline 10 & 10 & 1,370 & 1,180 & 1,660 & 1,330 & 1,340 & 1,190 & 1,540 & 1,330 & 1,150 & 1,640 \\
\hline 4 & 25 & 1,830 & 1,530 & 2,320 & 1,700 & 1,720 & 1,500 & 2,050 & 1,720 & 1,440 & 2,330 \\
\hline 2 & 50 & 2,220 & 1,810 & 2,900 & 1,990 & 2,040 & 1,750 & 2,480 & 2,040 & 1,650 & 3,000 \\
\hline 1 & 100 & 2,650 & 2,120 & 3,580 & 2,300 & 2,390 & 2,010 & 2,970 & 2,380 & 1,870 & 3,840 \\
\hline 0.5 & 200 & 3,130 & 2,450 & 4,370 & 2,630 & 2,760 & 2,290 & 3,500 & 2,750 & 2,090 & 4,880 \\
\hline 0.2 & 500 & 3,850 & 2,940 & 5,600 & 3,090 & 3,300 & 2,690 & 4,290 & 3,290 & 2,380 & 6,640 \\
\hline${ }^{\mathrm{a}} \mathrm{Actua}$ & ds $1938-1$ & 84 extended us & ng Little R & er near Har & CT $(011230$ & & & & & & \\
\hline top Riv & r Columb & CT 101120 & 300) & & & & & & & & \\
\hline & & & $933-1984$ & & & & & $33-2010^{\mathrm{a}}$ & & & \\
\hline 20 & 5 & 3,360 & 2,920 & 3,960 & 3,380 & 3,370 & 3,040 & 3,810 & 3,370 & 2,950 & 3,970 \\
\hline 10 & 10 & 4,460 & 3,800 & 5,460 & 4,310 & 4,330 & 3,830 & 5,010 & 4,330 & 3,710 & 5,390 \\
\hline & & & & & & 1952 & & & & & \\
\hline 20 & 5 & 1,410 & 1,240 & 1,630 & 1,410 & -- & -- & -- & 1,370 & 1,180 & 1,620 \\
\hline 10 & 10 & 1,810 & 1,570 & 2,170 & 1,800 & -- & -- & -- & 1,760 & 1,500 & 2,200 \\
\hline 4 & 25 & 2,390 & 2,020 & 2,980 & 2,340 & -- & -- & -- & 2,320 & 1,910 & 3,200 \\
\hline 2 & 50 & 2,870 & 2,370 & 3,680 & 2,770 & -- & -- & -- & 2,780 & 2,220 & 4,200 \\
\hline 1 & 100 & 3,390 & 2,750 & 4,460 & 3,220 & -- & -- & -- & 3,280 & 2,530 & 5,470 \\
\hline 0.5 & 200 & 3,960 & 3,160 & 5,330 & 3,710 & -- & -- & -- & 3,820 & 2,840 & 7,060 \\
\hline 0.2 & 500 & 4,780 & 3,730 & 6,640 & 4,400 & -- & -- & -- & 4,620 & 3,260 & 9,790 \\
\hline${ }^{\mathrm{a}} 61 \mathrm{ye}$ & ctual rec & but "histor & I" record s & ned 75 yec & wer perce & reshold o & $0 \mathrm{ft}^{3} / \mathrm{s}$ & EMA & $37-51$. & & \\
\hline Moosu & at Moc & O, CT 101126 & 500) & & & & & & & & \\
\hline & & & $933-1984$ & & & & & $33-2010^{a}$ & & & \\
\hline 20 & 5 & 2,230 & 1,990 & 2,560 & 2,280 & 2,280 & 2,060 & 2,560 & 2,290 & 2,020 & 2,650 \\
\hline 10 & 10 & 2,820 & 2,460 & 3,330 & 2,810 & 2,840 & 2,540 & 3,250 & 2,860 & 2,490 & 3,450 \\
\hline 4 & 25 & 3,640 & 3,110 & 4,490 & 3,510 & 3,600 & 3,160 & 4,240 & 3,630 & 3,070 & 4,750 \\
\hline 2 & 50 & 4,330 & 3,620 & 5,490 & 4,040 & 4,210 & 3,630 & 5,060 & 4,240 & 3,500 & 5,960 \\
\hline 1 & 100 & 5,080 & 4,170 & 6,620 & 4,580 & 4,850 & 4,130 & 5,930 & 4,880 & 3,910 & 7,400 \\
\hline 0.5 & 200 & 5,910 & 4,760 & 7,900 & 5,140 & 5,520 & 4,640 & 6,870 & 5,560 & 4,320 & 9,110 \\
\hline 0.2 & 500 & 7,120 & 5,600 & 9,840 & 5,910 & 6,460 & 5,350 & 8,230 & 6,520 & 4,840 & 11,900 \\
\hline
\end{tabular}


Table 7. Estimated magnitude of flood flows and confidence limits for selected annual exceedance probabilities at selected streamgages in Rhode Island, Connecticut, and Massachusetts for the period of record through 2010.-Continued

\begin{tabular}{|c|c|c|c|c|c|c|c|c|c|c|c|}
\hline \multirow{4}{*}{$\begin{array}{l}\text { AEP } \\
(\%)\end{array}$} & \multirow{4}{*}{$\begin{array}{c}\text { Return } \\
\text { interval } \\
\text { (years) }\end{array}$} & \multirow{2}{*}{\multicolumn{3}{|c|}{$\begin{array}{c}\text { Period of record analysis } \\
\text { B17B }\end{array}$}} & \multirow{4}{*}{$\begin{array}{c}\text { Systematic } \\
\text { peak flow } \\
\text { estimate }\end{array}$} & \multicolumn{6}{|c|}{ Extended record analysis } \\
\hline & & & & & & \multicolumn{3}{|c|}{ B17B } & \multicolumn{3}{|c|}{ EMA } \\
\hline & & \multirow{2}{*}{$\begin{array}{l}\text { Peak flow } \\
\text { estimate }\end{array}$} & \multicolumn{2}{|c|}{ 95\% confidence } & & \multirow{2}{*}{$\begin{array}{l}\text { Peak flow } \\
\text { estimate }\end{array}$} & \multicolumn{2}{|c|}{$95 \%$ confidence } & \multirow{2}{*}{$\begin{array}{l}\text { Peak flow } \\
\text { estimate }\end{array}$} & \multicolumn{2}{|c|}{$95 \%$ confidence } \\
\hline & & & Lower & Upper & & & Lower & Upper & & Lower & Upper \\
\hline \multicolumn{12}{|c|}{ Connecticut streamgages-Continued } \\
\hline \multicolumn{12}{|c|}{ Mount Hope River near Warrenville, CT (01121000) } \\
\hline & & \multicolumn{10}{|c|}{$1941-2010$} \\
\hline 20 & 5 & 1,760 & 1,560 & 2,020 & 1,760 & -- & -- & -- & 1,730 & 1,490 & 2,090 \\
\hline 10 & 10 & 2,370 & 2,060 & 2,810 & 2,370 & -- & -- & -- & 2,270 & 1,910 & 2,940 \\
\hline 4 & 25 & 3,340 & 2,810 & 4,140 & 3,350 & -- & -- & -- & 3,090 & 2,480 & 4,560 \\
\hline 2 & 50 & 4,220 & 3,480 & 5,410 & 4,260 & -- & -- & -- & 3,800 & 2,940 & 6,320 \\
\hline 1 & 100 & 5,270 & 4,240 & 6,970 & 5,330 & -- & -- & -- & 4,610 & 3,420 & 8,720 \\
\hline 0.5 & 200 & 6,500 & 5,110 & 8,870 & 6,600 & -- & -- & -- & 5,530 & 3,930 & 12,000 \\
\hline 0.2 & 500 & 8,480 & 6,470 & 12,000 & 8,650 & -- & -- & -- & 6,950 & 4,650 & 18,100 \\
\hline \multicolumn{12}{|c|}{${ }^{b}$ Lower confidence limits set 12 peaks above $2,250 \mathrm{ft}^{3} / \mathrm{s}$ (average $-18.4 \%$ ) for EMA analysis. } \\
\hline \multicolumn{12}{|c|}{ Natchaug River at Willimantic, CT (01122000) } \\
\hline & & \multicolumn{3}{|c|}{ 1931-1951 (pre-flood control) } & \multicolumn{7}{|c|}{$1931-2010^{a, b}$} \\
\hline 20 & 5 & 6,030 & 4,730 & 8,290 & 6,620 & 6,690 & 5,930 & 7,660 & 6,350 & 5,460 & 7,700 \\
\hline 10 & 10 & 8,660 & 6,550 & 13,000 & 9,350 & 9,320 & 8,100 & 11,000 & 8,510 & 7,100 & 11,200 \\
\hline 4 & 25 & 13,300 & 9,440 & 22,500 & 14,100 & 13,800 & 11,600 & 17,100 & 11,900 & 9,470 & 18,300 \\
\hline 2 & 50 & 17,900 & 12,100 & 33,300 & 18,900 & 18,100 & 14,800 & 23,300 & 15,000 & 11,400 & 26,400 \\
\hline 1 & 100 & 23,800 & 15,300 & 48,500 & 25,000 & 23,500 & 18,800 & 31,300 & 18,700 & 13,600 & 38,200 \\
\hline 0.5 & 200 & 31,200 & 19,100 & 69,800 & 32,800 & 30,200 & 23,400 & 41,600 & 23,000 & 15,900 & 55,100 \\
\hline 0.2 & 500 & 44,300 & 25,400 & 111,000 & 46,400 & 41,400 & 31,200 & 59,800 & 30,000 & 19,300 & 89,200 \\
\hline \multicolumn{12}{|c|}{$\begin{array}{l}{ }^{a} \text { Actual pre-flood control records } 1931-1951 \text { extended using Willimantic River near Coventry, CT (01119500). } \\
\text { b Lower confidence limits set } 18 \text { peaks above } 5,370 \mathrm{ft}^{3} / \mathrm{s} \text { by an average - } 18 \% \text { for EMA analysis. }\end{array}$} \\
\hline Pendletc & rook Hill $n$ & ear Clark Fall & s, CT 1011 & $8300)$ & & & & & & & \\
\hline & & & 1959-2010 & & & & & $2-2010^{a, b}$ & & & \\
\hline 20 & 5 & 220 & 190 & 260 & 200 & 200 & 180 & 230 & 200 & 170 & 230 \\
\hline 10 & 10 & 280 & 240 & 340 & 260 & 260 & 220 & 300 & 250 & 210 & 320 \\
\hline 4 & 25 & 370 & 310 & 470 & 340 & 340 & 290 & 420 & 330 & 270 & 470 \\
\hline 2 & 50 & 450 & 370 & 580 & 410 & 420 & 350 & 520 & 400 & 320 & 620 \\
\hline 1 & 100 & 530 & 430 & 710 & 480 & 500 & 410 & 640 & 470 & 360 & 820 \\
\hline 0.5 & 200 & 620 & 490 & 860 & 570 & 590 & 480 & 780 & $\mathbf{5 5 0}$ & 410 & 1070 \\
\hline 0.2 & 500 & 760 & 580 & 1080 & 690 & 730 & 570 & 990 & 670 & 470 & 1520 \\
\hline $\begin{array}{l}{ }^{\mathrm{a}} \text { Actual } \\
{ }^{\mathrm{b}} \text { Error } \mathrm{c}\end{array}$ & $\begin{array}{l}\text { ds 1959-2 } \\
\% \text { assigne }\end{array}$ & $\begin{array}{l}10 \text { extended us } \\
\text { to } 2010 \text { peak fc }\end{array}$ & $\begin{array}{l}\text { ing Wood } \mathrm{F} \\
\text { r EMA ana }\end{array}$ & $\begin{array}{l}\text { iver at Hope } \\
\text { ysis. }\end{array}$ & RI (0111 & & & & & & \\
\hline Quineba & iiver at $\mathrm{Qu}$ & inebaug, CT & 01124000 & & & & & & & & \\
\hline & & $1932-195$ & (pre-floo & d control) & & & & $9-2010^{a}$ & & & \\
\hline 20 & 5 & 4,820 & 3,620 & 6,920 & 4,190 & 4,270 & 3,720 & 4,980 & 4,250 & 3,520 & 5,420 \\
\hline 10 & 10 & 7,950 & 5,700 & 12,600 & 6,460 & 6,440 & 5,490 & 7,790 & 6,320 & 5,020 & 8,970 \\
\hline 4 & 25 & 14,400 & 9,560 & 26,200 & 10,900 & 10,500 & 8,600 & 13,400 & 10,100 & 7,440 & 17,400 \\
\hline 2 & 50 & 21,900 & 13,600 & 44,300 & 15,800 & 14,800 & 11,700 & 19,600 & 13,900 & 9,670 & 28,700 \\
\hline 1 & 100 & 32,700 & 19,100 & 73,500 & 22,700 & 20,500 & 15,800 & 28,400 & 18,900 & 12,300 & 47,400 \\
\hline 0.5 & 200 & 48,200 & 26,400 & 120,000 & 32,300 & 28,100 & 21,000 & 40,500 & 25,500 & 15,400 & 78,200 \\
\hline 0.2 & 500 & 79,000 & 39,900 & 226,000 & 50,700 & 42,000 & 30,100 & 63,800 & 37,100 & 20,400 & 151,000 \\
\hline
\end{tabular}


Table 7. Estimated magnitude of flood flows and confidence limits for selected annual exceedance probabilities at selected streamgages in Rhode Island, Connecticut, and Massachusetts for the period of record through 2010.—Continued

\begin{tabular}{|c|c|c|c|c|c|c|c|c|c|c|c|}
\hline \multirow{4}{*}{$\begin{array}{l}\text { AEP } \\
(\%)\end{array}$} & \multirow{4}{*}{$\begin{array}{l}\text { Return } \\
\text { interval } \\
\text { (years) }\end{array}$} & \multirow{2}{*}{\multicolumn{3}{|c|}{$\begin{array}{c}\text { Period of record analysis } \\
\text { B17B }\end{array}$}} & \multirow{4}{*}{$\begin{array}{c}\text { Systematic } \\
\text { peak flow } \\
\text { estimate }\end{array}$} & \multicolumn{6}{|c|}{ Extended record analysis } \\
\hline & & & & & & \multicolumn{3}{|c|}{ B17B } & \multicolumn{3}{|c|}{ EMA } \\
\hline & & \multirow{2}{*}{$\begin{array}{l}\text { Peak flow } \\
\text { estimate }\end{array}$} & \multicolumn{2}{|c|}{ 95\% confidence } & & \multirow{2}{*}{$\begin{array}{l}\text { Peak flow } \\
\text { estimate }\end{array}$} & \multicolumn{2}{|c|}{$95 \%$ confidence } & \multirow{2}{*}{$\begin{array}{l}\text { Peak flow } \\
\text { estimate }\end{array}$} & \multicolumn{2}{|c|}{ 95\% confidence } \\
\hline & & & Lower & Upper & & & Lower & Upper & & Lower & Upper \\
\hline \multicolumn{12}{|c|}{ Connecticut streamgages-Continued } \\
\hline \multicolumn{12}{|c|}{ Safford Brook near Woodstock Valley, CT (01120500) } \\
\hline & & \multicolumn{3}{|c|}{$1951-1981$} & \multicolumn{7}{|c|}{$1941-2010^{\mathrm{a}, \mathrm{b}}$} \\
\hline 20 & 5 & 520 & 440 & 630 & 430 & 430 & 400 & 480 & 400 & 360 & 470 \\
\hline 10 & 10 & 660 & 550 & 840 & 540 & 550 & 490 & 620 & 490 & 430 & 600 \\
\hline 4 & 25 & 870 & 710 & 1,170 & 700 & 710 & 620 & 830 & 620 & 530 & 830 \\
\hline 2 & 50 & 1,000 & 830 & 1,480 & 840 & 840 & 720 & 1,020 & 720 & 600 & 1,050 \\
\hline 1 & 100 & 1,200 & 960 & 1,830 & 983 & 990 & 840 & 1,230 & 830 & 670 & 1,330 \\
\hline 0.5 & 200 & 1,500 & 1,100 & 2,240 & 1,140 & 1,160 & 960 & 1,470 & 950 & 740 & 1,670 \\
\hline 0.2 & 500 & 1,800 & 1,310 & 2,900 & 1,390 & 1,400 & 1,140 & 1,840 & 1,120 & 830 & 2,240 \\
\hline
\end{tabular}

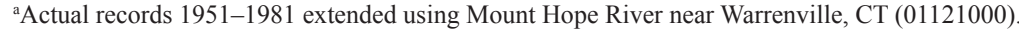

${ }^{b}$ Lower confidence limits set for $1951-81$ peaks from 0 to $-45 \%$ (-19.4\% average) for EMA analysis. Salmon River near East Hampton, CT (01193500)

\begin{tabular}{|c|c|c|c|c|c|c|c|c|c|c|c|}
\hline \multirow[b]{2}{*}{20} & \multirow[b]{2}{*}{5} & \multicolumn{10}{|c|}{ 1929-2010 } \\
\hline & & 5,140 & 4,570 & 5,870 & 5,140 & -- & -- & -- & 5,060 & 4,350 & 6,100 \\
\hline 10 & 10 & 6,970 & 6,080 & 8,200 & 6,970 & -- & -- & -- & 6,770 & 5,670 & 8,750 \\
\hline 4 & 25 & 9,870 & 8,370 & 12,100 & 9,850 & -- & -- & -- & 9,400 & 7,530 & 13,800 \\
\hline 2 & 50 & 12,500 & 10,400 & 15,800 & 12,500 & -- & -- & -- & 11,700 & 9,030 & 19,400 \\
\hline 1 & 100 & 15,600 & 12,700 & 20,300 & 15,600 & -- & -- & -- & 14,400 & 10,600 & 26,900 \\
\hline 0.5 & 200 & 19,300 & 15,300 & 25,800 & 19,200 & -- & -- & -- & 17,500 & 12,400 & 37,300 \\
\hline 0.2 & 500 & 25,100 & 19,400 & 34,800 & 24,900 & -- & -- & -- & 22,400 & 14,800 & 57,000 \\
\hline
\end{tabular}

${ }^{b}$ Lower confidence limits set 1956, 1973, 1974, 1979, and 1982 peaks of $-12,-21,-12,-26$, and -20\%, respectively, for EMA analysis. Shetucket River near Willimantic, CT (01122500)

\begin{tabular}{|c|c|c|c|c|c|c|c|c|c|c|c|}
\hline \multirow[b]{2}{*}{20} & \multirow[b]{2}{*}{5} & \multicolumn{3}{|c|}{ 1904-51 (pre-flood control) } & \multicolumn{7}{|c|}{$1904-2010^{\mathrm{a}}$} \\
\hline & & 11,000 & 9,040 & 14,000 & 12,800 & 12,700 & 11,400 & 14,300 & 11,600 & 9,910 & 14,100 \\
\hline 10 & 10 & 15,300 & 12,200 & 20,800 & 17,800 & 17,200 & 15,200 & 20,000 & 16,500 & 13,700 & 21,500 \\
\hline 4 & 25 & 22,600 & 17,200 & 33,700 & 26,500 & 24,800 & 21,200 & 30,000 & 24,600 & 19,300 & 36,600 \\
\hline 2 & 50 & 29,800 & 21,800 & 47,700 & 35,200 & 32,000 & 26,800 & 40,000 & 32,200 & 24,200 & 54,000 \\
\hline 1 & 100 & 38,800 & 27,200 & 66,500 & 46,100 & 40,700 & 33,300 & 52,500 & 41,400 & 29,600 & 79,200 \\
\hline 0.5 & 200 & 50,000 & 33,600 & 91,700 & 60,000 & 51,300 & 41,000 & 68,200 & 52,400 & 35,600 & 115,000 \\
\hline 0.2 & 500 & 69,200 & 44,000 & 139,000 & 84,100 & 69,000 & 53,400 & 95,400 & 70,500 & 44,600 & 188,000 \\
\hline
\end{tabular}

${ }^{a}$ Actual pre-flood control records 1904-1906, 1920-1921, 1929-1951, after 1951 record extended using Willimantic River near Coventry, CT (01119500).

b87 years of actual record, but "historical" record spanned 107 years; Lower confidence limits for 1955 and 2006 peaks of -5.3 and -5.4\%, respectively, for EMA analysis; Lower perception threshold of 3,500 ft $3 / \mathrm{s}$ used in EMA during record gaps from 1907-19 and 1922-28.

Willimantic River near Coventry, CT (01119500)

\begin{tabular}{|c|c|c|c|c|c|c|c|c|c|c|c|}
\hline \multirow[b]{2}{*}{20} & \multirow[b]{2}{*}{5} & \multicolumn{10}{|c|}{ 1932-2010 } \\
\hline & & 3,990 & 3,510 & 4,620 & 3,960 & -- & -- & -- & 3,970 & 3,330 & 4,990 \\
\hline 10 & 10 & 5,670 & 4,880 & 6,800 & 5,680 & -- & -- & -- & 5,590 & 4,520 & 7,760 \\
\hline 4 & 25 & 8,560 & 7,110 & 10,800 & 8,730 & -- & -- & -- & 8,320 & 6,330 & 13,800 \\
\hline 2 & 50 & 11,400 & 9,210 & 14,900 & 11,800 & -- & -- & -- & 11,000 & 7,900 & 21,300 \\
\hline 1 & 100 & 15,000 & 11,800 & 20,300 & 15,700 & -- & -- & -- & 14,200 & 9,670 & 32,900 \\
\hline 0.5 & 200 & 19,400 & 14,800 & 27,300 & 20,800 & -- & -- & -- & 18,200 & 11,700 & 50,700 \\
\hline 0.2 & 500 & 27,000 & 20,000 & 39,900 & 29,600 & -- & -- & -- & 25,000 & 14,700 & 89,700 \\
\hline
\end{tabular}

'Errors of $-11,-12,-5$ and $-8 \%$ assigned to 1936, 1955, 1982, and 2006 peaks, respectively, for EMA analysis. Yantic River at Yantic, CT (01127500)

\begin{tabular}{|c|c|c|c|c|c|c|c|c|c|c|c|}
\hline \multirow[b]{2}{*}{20} & \multirow[b]{2}{*}{5} & \multicolumn{10}{|c|}{ 1931-2010 } \\
\hline & & 4,410 & 3,940 & 5,010 & 4,420 & -- & -- & -- & 4,380 & 3,800 & 5,200 \\
\hline 10 & 10 & 5,800 & 5,090 & 6,770 & 5,780 & -- & -- & -- & 5,710 & 4,850 & 7,180 \\
\hline 4 & 25 & 7,870 & 6,740 & 9,520 & 7,770 & -- & -- & -- & 7,660 & 6,270 & 10,700 \\
\hline 2 & 50 & 9,660 & 8,120 & 12,000 & 9,460 & -- & -- & -- & 9,310 & 7,370 & 14,300 \\
\hline 1 & 100 & 11,700 & 9,630 & 14,900 & 11,300 & -- & -- & -- & 11,100 & 8,500 & 19,000 \\
\hline 0.5 & 200 & 13,900 & 11,300 & 18,200 & 13,400 & -- & -- & -- & 13,200 & 9,670 & 25,000 \\
\hline 0.2 & 500 & 17,400 & 13,800 & 23,400 & 16,600 & -- & -- & -- & 16,200 & 11,300 & 35,700 \\
\hline
\end{tabular}


Table 13. Magnitude and variance of 20-, 10-, 4-, 2-, 1-, 0.5-, and 0.2-percent annual exceedance probability floods determined from at-site analyses, regional regression equations, and weighted independent estimates.-Continued

[At-site, Bulletin 17B or expected moments algorithm results highlighted in table 7; Values may not exactly match because of rounding; $\mathrm{ft}^{3} / \mathrm{s}$, cubic feet per second; RI, Rhode Island; MA, Massachusetts; CT, Connecticut]

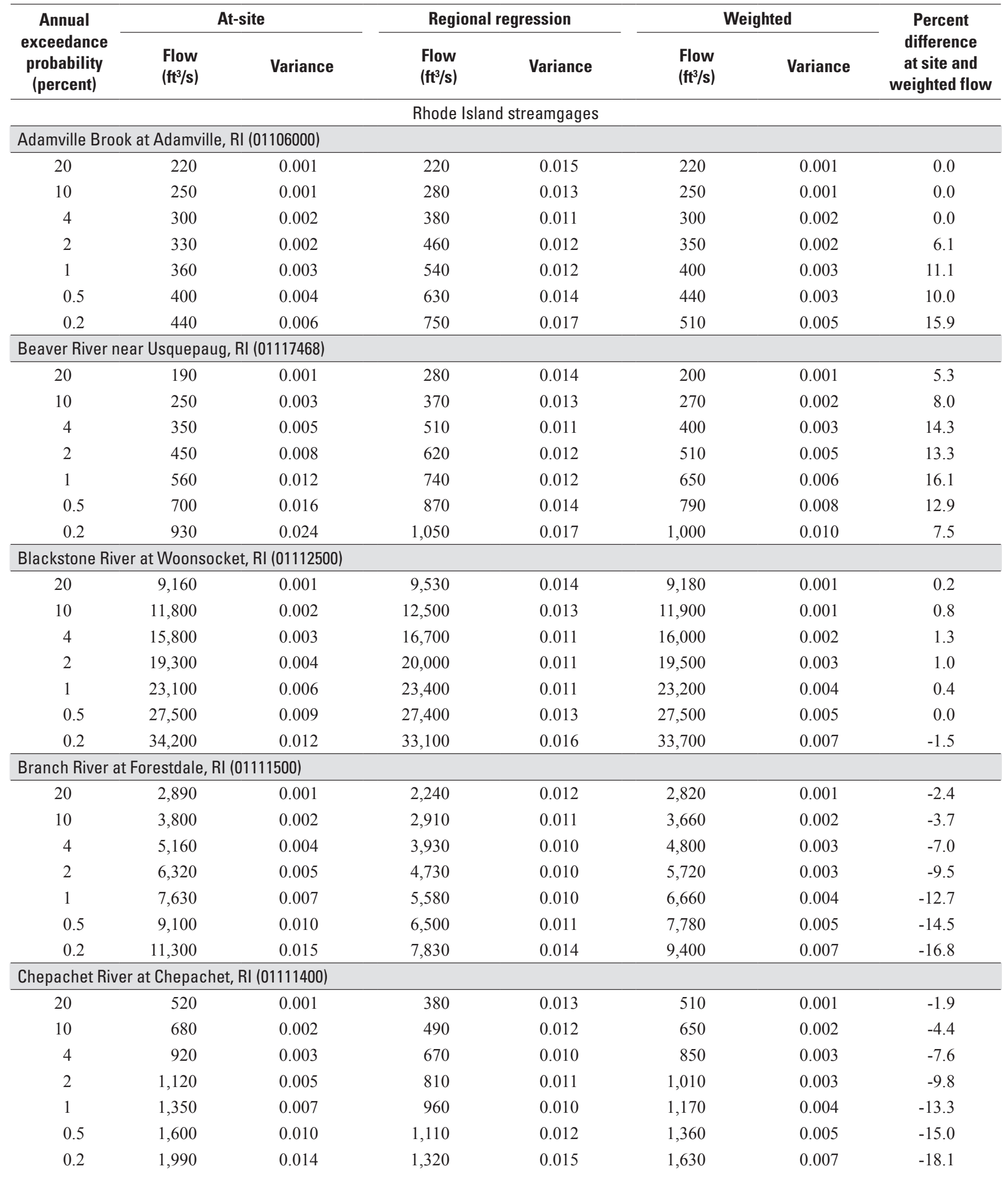


Table 13. Magnitude and variance of 20-, 10-, 4-, 2-, 1-, 0.5-, and 0.2-percent annual exceedance probability floods determined from at-site analyses, regional regression equations, and weighted independent estimates.-Continued

[At-site, Bulletin 17B or expected moments algorithm results highlighted in table 7; Values may not exactly match because of rounding; $\mathrm{ft}^{3} / \mathrm{s}$, cubic feet per second; RI, Rhode Island; MA, Massachusetts; CT, Connecticut]

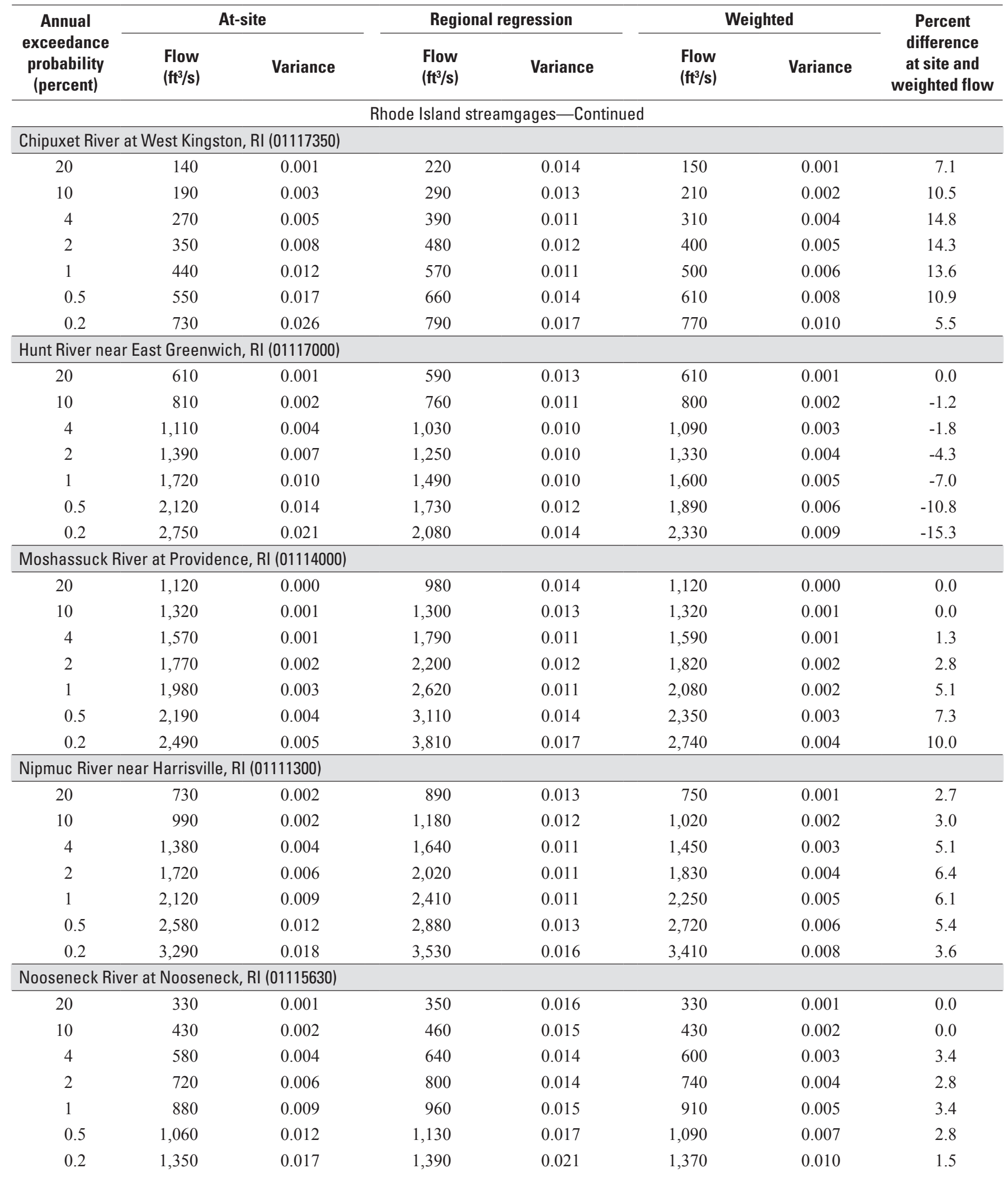


Table 13. Magnitude and variance of 20-, 10-, 4-, 2-, 1-, 0.5-, and 0.2-percent annual exceedance probability floods determined from at-site analyses, regional regression equations, and weighted independent estimates.-Continued

[At-site, Bulletin 17B or expected moments algorithm results highlighted in table 7; Values may not exactly match because of rounding; $\mathrm{ft}^{3} / \mathrm{s}$, cubic feet per second; RI, Rhode Island; MA, Massachusetts; CT, Connecticut]

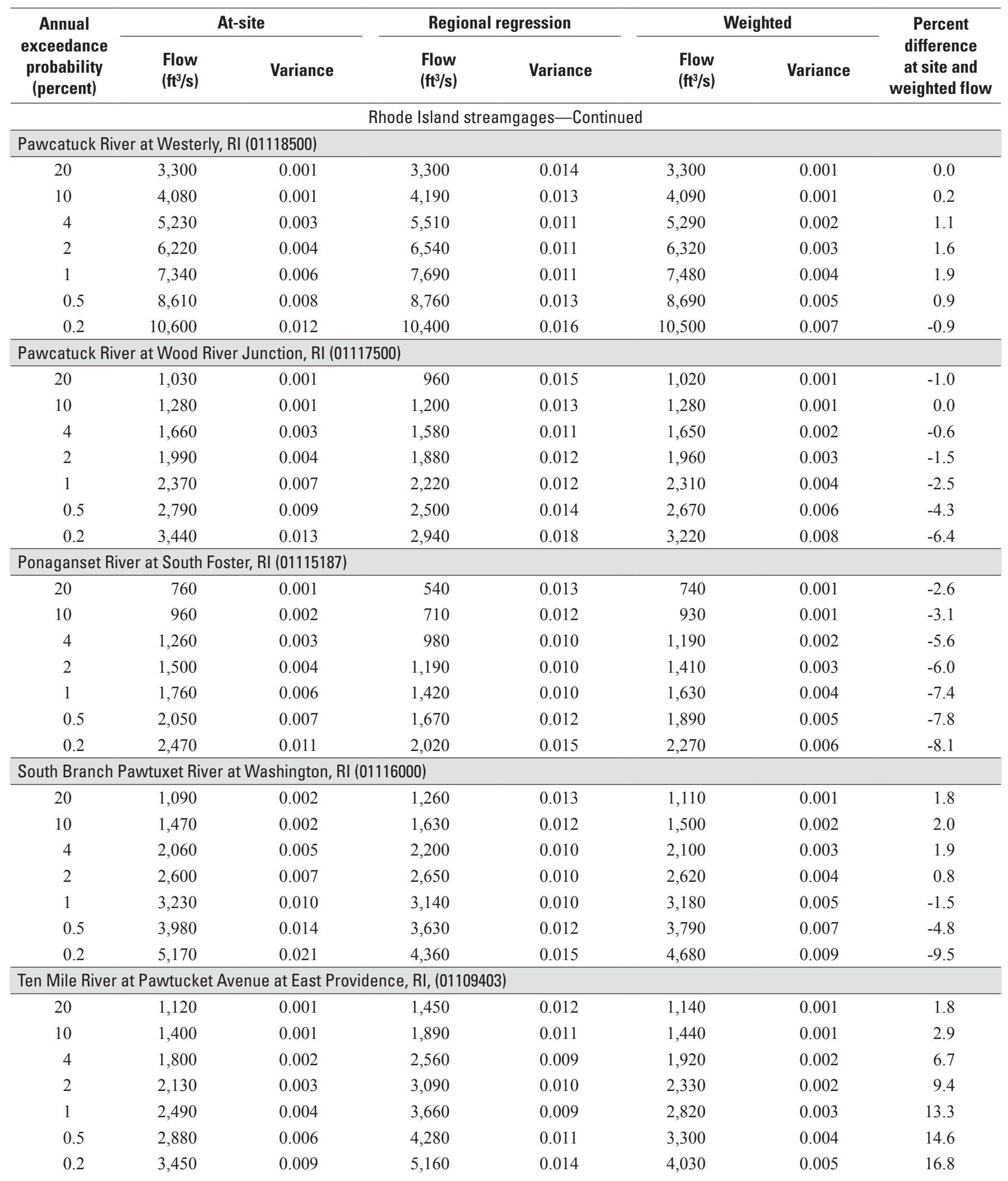


Table 13. Magnitude and variance of 20-, 10-, 4-, 2-, 1-, 0.5-, and 0.2-percent annual exceedance probability floods determined from at-site analyses, regional regression equations, and weighted independent estimates.-Continued

[At-site, Bulletin 17B or expected moments algorithm results highlighted in table 7; Values may not exactly match because of rounding; $\mathrm{ft}^{3} / \mathrm{s}$, cubic feet per second; RI, Rhode Island; MA, Massachusetts; CT, Connecticut]

\begin{tabular}{|c|c|c|c|c|c|c|c|}
\hline \multirow{2}{*}{$\begin{array}{c}\text { Annual } \\
\text { exceedance } \\
\text { probability } \\
\text { (percent) }\end{array}$} & \multicolumn{2}{|c|}{ At-site } & \multicolumn{2}{|c|}{ Regional regression } & \multicolumn{2}{|c|}{ Weighted } & \multirow{2}{*}{$\begin{array}{c}\text { Percent } \\
\text { difference } \\
\text { at site and } \\
\text { weighted flow }\end{array}$} \\
\hline & $\begin{array}{l}\text { Flow } \\
\left(\mathrm{ft}^{3} / \mathrm{s}\right)\end{array}$ & Variance & $\begin{array}{l}\text { Flow } \\
\left(\mathrm{ft}^{3} / \mathrm{s}\right)\end{array}$ & Variance & $\begin{array}{l}\text { Flow } \\
\left(\mathrm{ft}^{3} / \mathrm{s}\right)\end{array}$ & Variance & \\
\hline \multicolumn{8}{|c|}{ Rhode Island streamgages-Continued } \\
\hline \multicolumn{8}{|c|}{ Usquepaug River near Usquepaug, RI (01117420) } \\
\hline 20 & 550 & 0.001 & 870 & 0.013 & 570 & 0.001 & 3.6 \\
\hline 10 & 710 & 0.002 & 1,130 & 0.012 & 750 & 0.002 & 5.6 \\
\hline 4 & 950 & 0.004 & 1,540 & 0.010 & 1,070 & 0.003 & 12.6 \\
\hline 2 & 1,160 & 0.006 & 1,870 & 0.011 & 1,360 & 0.004 & 17.2 \\
\hline 1 & 1,400 & 0.008 & 2,220 & 0.011 & 1,710 & 0.005 & 22.1 \\
\hline 0.5 & 1,680 & 0.011 & 2,580 & 0.013 & 2,060 & 0.006 & 22.6 \\
\hline 0.2 & 2,130 & 0.016 & 3,110 & 0.015 & 2,580 & 0.008 & 21.1 \\
\hline \multicolumn{8}{|c|}{ Wood River near Arcadia, RI (01117800) } \\
\hline 20 & 620 & 0.001 & 640 & 0.061 & 620 & 0.001 & 0.0 \\
\hline 10 & 810 & 0.002 & 820 & 0.059 & 810 & 0.002 & 0.0 \\
\hline 4 & 1,100 & 0.004 & 1,110 & 0.058 & 1,100 & 0.004 & 0.0 \\
\hline 2 & 1,370 & 0.007 & 1,340 & 0.064 & 1,360 & 0.006 & -0.7 \\
\hline 1 & 1,680 & 0.010 & 1,590 & 0.072 & 1,640 & 0.009 & -2.4 \\
\hline 0.5 & 2,050 & 0.014 & 1,830 & 0.081 & 1,940 & 0.012 & -5.4 \\
\hline 0.2 & 2,630 & 0.020 & 2,200 & 0.101 & 2,390 & 0.017 & -9.1 \\
\hline \multicolumn{8}{|c|}{ Wood River at Hope Valley, RI (01118000) } \\
\hline 20 & 1,310 & 0.001 & 1,290 & 0.014 & 1,310 & 0.001 & 0.0 \\
\hline 10 & 1,650 & 0.002 & 1,670 & 0.012 & 1,650 & 0.001 & 0.0 \\
\hline 4 & 2,170 & 0.003 & 2,240 & 0.011 & 2,190 & 0.002 & 0.9 \\
\hline 2 & 2,630 & 0.005 & 2,700 & 0.011 & 2,650 & 0.004 & 0.8 \\
\hline 1 & 3,160 & 0.007 & 3,200 & 0.011 & 3,180 & 0.004 & 0.6 \\
\hline 0.5 & 3,760 & 0.011 & 3,690 & 0.013 & 3,730 & 0.006 & -0.8 \\
\hline 0.2 & 4,710 & 0.016 & 4,410 & 0.016 & 4,570 & 0.008 & -3.0 \\
\hline \multicolumn{8}{|c|}{ Woonasquatucket River at Centerdale, RI (01114500) } \\
\hline 20 & 920 & 0.001 & 830 & 0.013 & 910 & 0.001 & -1.1 \\
\hline 10 & 1,150 & 0.001 & 1,070 & 0.011 & 1,140 & 0.001 & -0.9 \\
\hline 4 & 1,470 & 0.002 & 1,440 & 0.010 & 1,460 & 0.002 & -0.7 \\
\hline 2 & 1,720 & 0.003 & 1,720 & 0.010 & 1,720 & 0.002 & 0.0 \\
\hline 1 & 1,990 & 0.005 & 2,040 & 0.010 & 2,000 & 0.003 & 0.5 \\
\hline 0.5 & 2,270 & 0.006 & 2,360 & 0.012 & 2,300 & 0.004 & 1.3 \\
\hline 0.2 & 2,670 & 0.009 & 2,820 & 0.014 & 2,720 & 0.005 & 1.9 \\
\hline \multicolumn{8}{|c|}{ Massachusetts streamgages } \\
\hline \multicolumn{8}{|c|}{ Kettle Brook at Worcester, MA (01109500) } \\
\hline 20 & 730 & 0.004 & 990 & 0.013 & 780 & 0.003 & 6.8 \\
\hline 10 & 1,080 & 0.006 & 1,290 & 0.012 & 1,150 & 0.004 & 6.5 \\
\hline 4 & 1,720 & 0.011 & 1,750 & 0.010 & 1,740 & 0.005 & 1.2 \\
\hline 2 & 2,350 & 0.016 & 2,110 & 0.011 & 2,200 & 0.006 & -6.4 \\
\hline 1 & 3,170 & 0.023 & 2,500 & 0.010 & 2,690 & 0.007 & -15.1 \\
\hline 0.5 & 4,200 & 0.032 & 2,930 & 0.012 & 3,230 & 0.009 & -23.1 \\
\hline 0.2 & 6,000 & 0.046 & 3,530 & 0.015 & 4,020 & 0.011 & -33.0 \\
\hline
\end{tabular}


Table 13. Magnitude and variance of 20-, 10-, 4-, 2-, 1-, 0.5-, and 0.2-percent annual exceedance probability floods determined from at-site analyses, regional regression equations, and weighted independent estimates.-Continued

[At-site, Bulletin 17B or expected moments algorithm results highlighted in table 7; Values may not exactly match because of rounding; $\mathrm{ft}^{3} / \mathrm{s}$, cubic feet per second; RI, Rhode Island; MA, Massachusetts; CT, Connecticut]

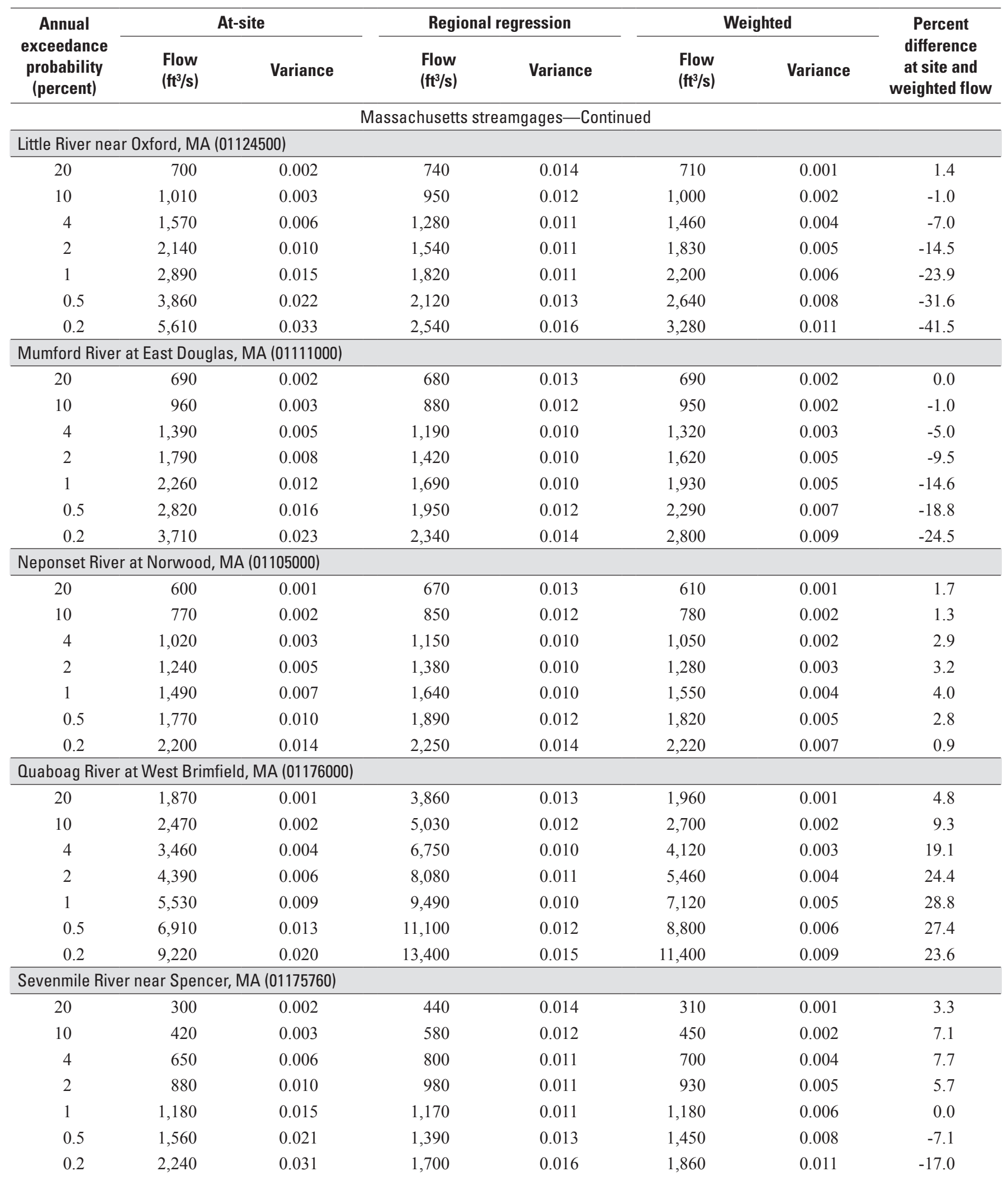


Table 13. Magnitude and variance of 20-, 10-, 4-, 2-, 1-, 0.5-, and 0.2-percent annual exceedance probability floods determined from at-site analyses, regional regression equations, and weighted independent estimates.-Continued

[At-site, Bulletin 17B or expected moments algorithm results highlighted in table 7; Values may not exactly match because of rounding; $\mathrm{ft}^{3} / \mathrm{s}$, cubic feet per second; RI, Rhode Island; MA, Massachusetts; CT, Connecticut]

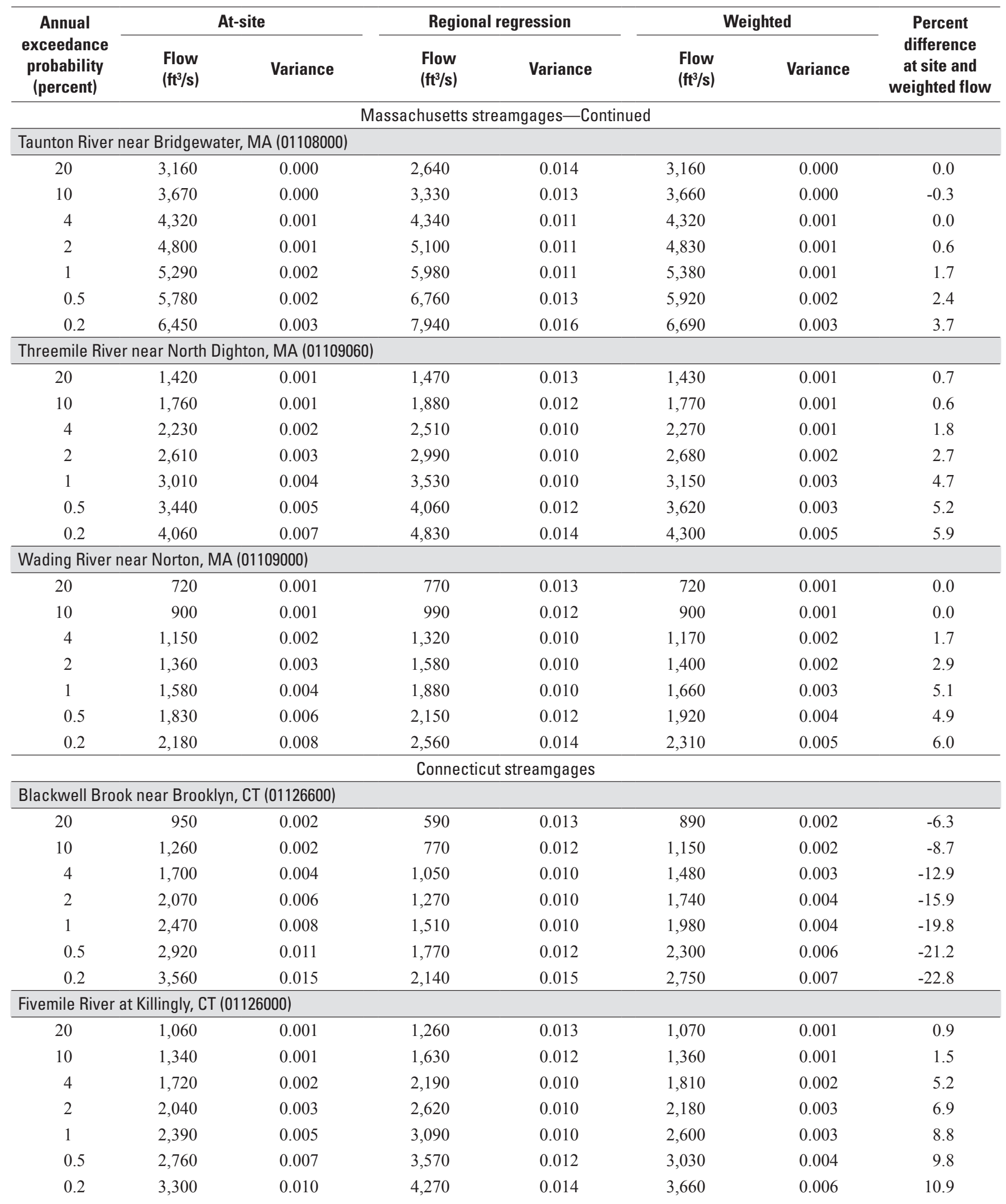


Table 13. Magnitude and variance of 20-, 10-, 4-, 2-, 1-, 0.5-, and 0.2-percent annual exceedance probability floods determined from at-site analyses, regional regression equations, and weighted independent estimates.-Continued

[At-site, Bulletin 17B or expected moments algorithm results highlighted in table 7; Values may not exactly match because of rounding; $\mathrm{ft}^{3} / \mathrm{s}$, cubic feet per second; RI, Rhode Island; MA, Massachusetts; CT, Connecticut]

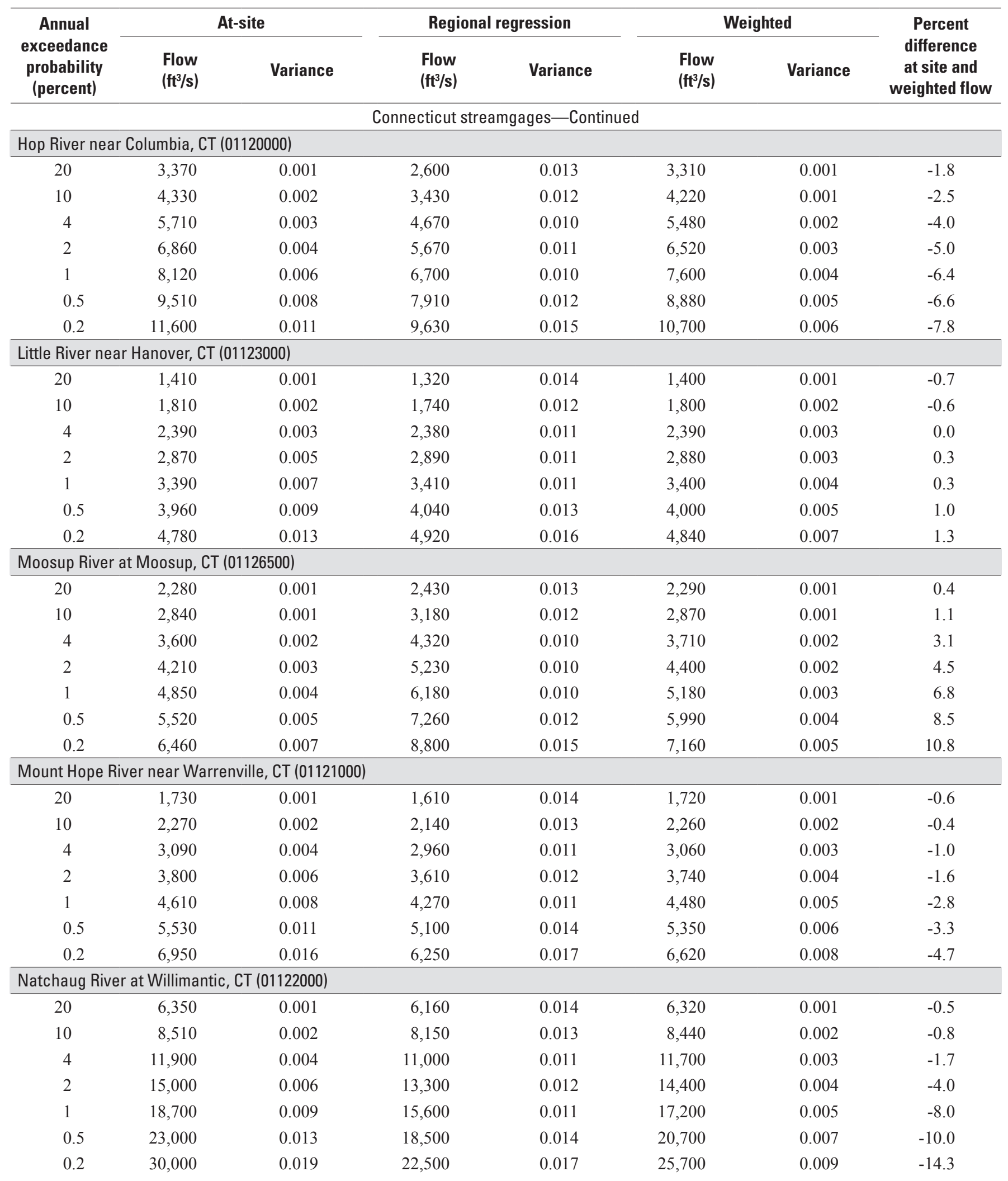


Table 13. Magnitude and variance of 20-, 10-, 4-, 2-, 1-, 0.5-, and 0.2-percent annual exceedance probability floods determined from at-site analyses, regional regression equations, and weighted independent estimates._-Continued

[At-site, Bulletin 17B or expected moments algorithm results highlighted in table 7; Values may not exactly match because of rounding; $\mathrm{ft}^{3} / \mathrm{s}$, cubic feet per second; RI, Rhode Island; MA, Massachusetts; CT, Connecticut]

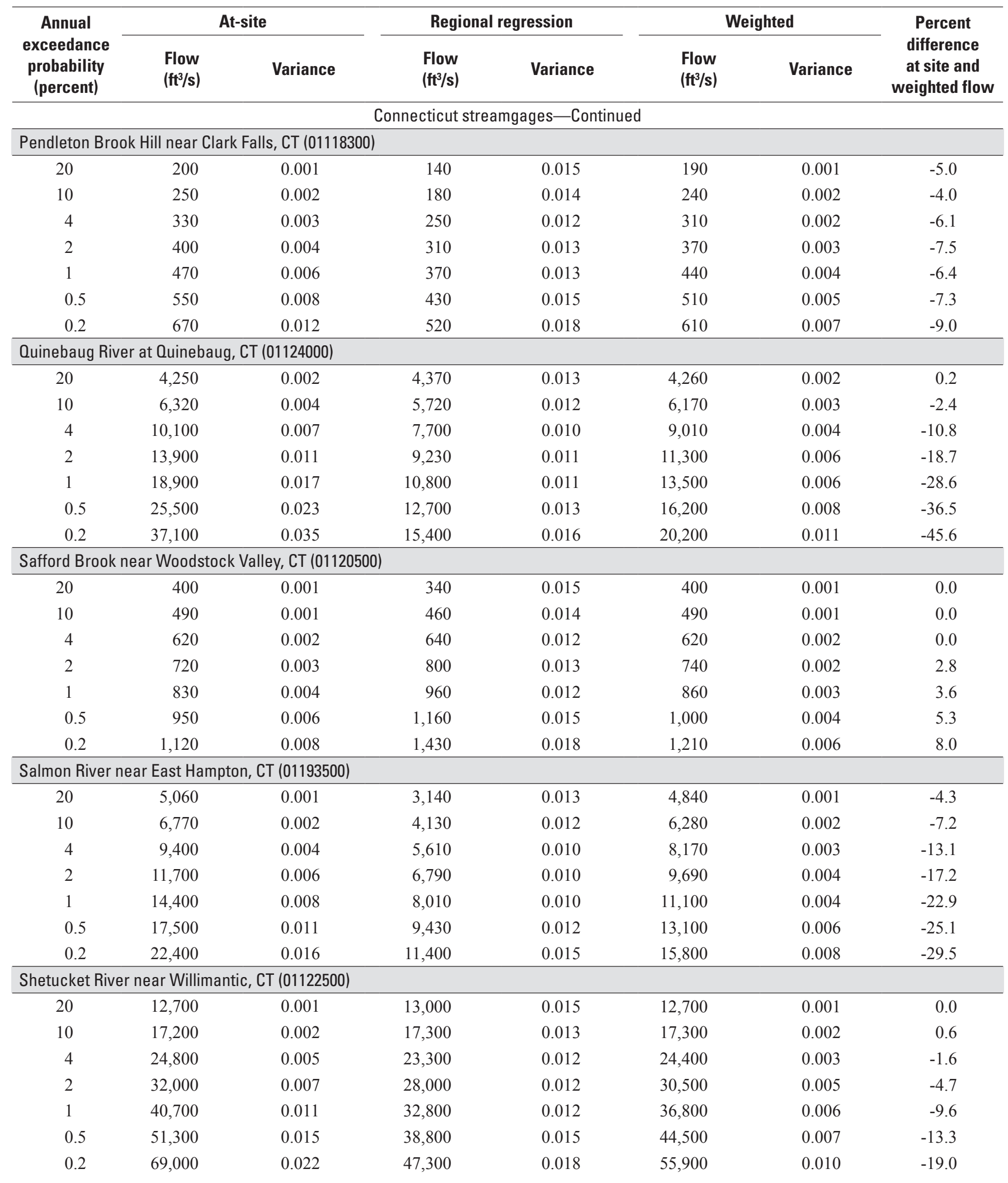


Table 13. Magnitude and variance of 20-, 10-, 4-, 2-, 1-, 0.5-, and 0.2-percent annual exceedance probability floods determined from at-site analyses, regional regression equations, and weighted independent estimates.-Continued

[At-site, Bulletin 17B or expected moments algorithm results highlighted in table 7; Values may not exactly match because of rounding; $\mathrm{ft}^{3} / \mathrm{s}$, cubic feet per second; RI, Rhode Island; MA, Massachusetts; CT, Connecticut]

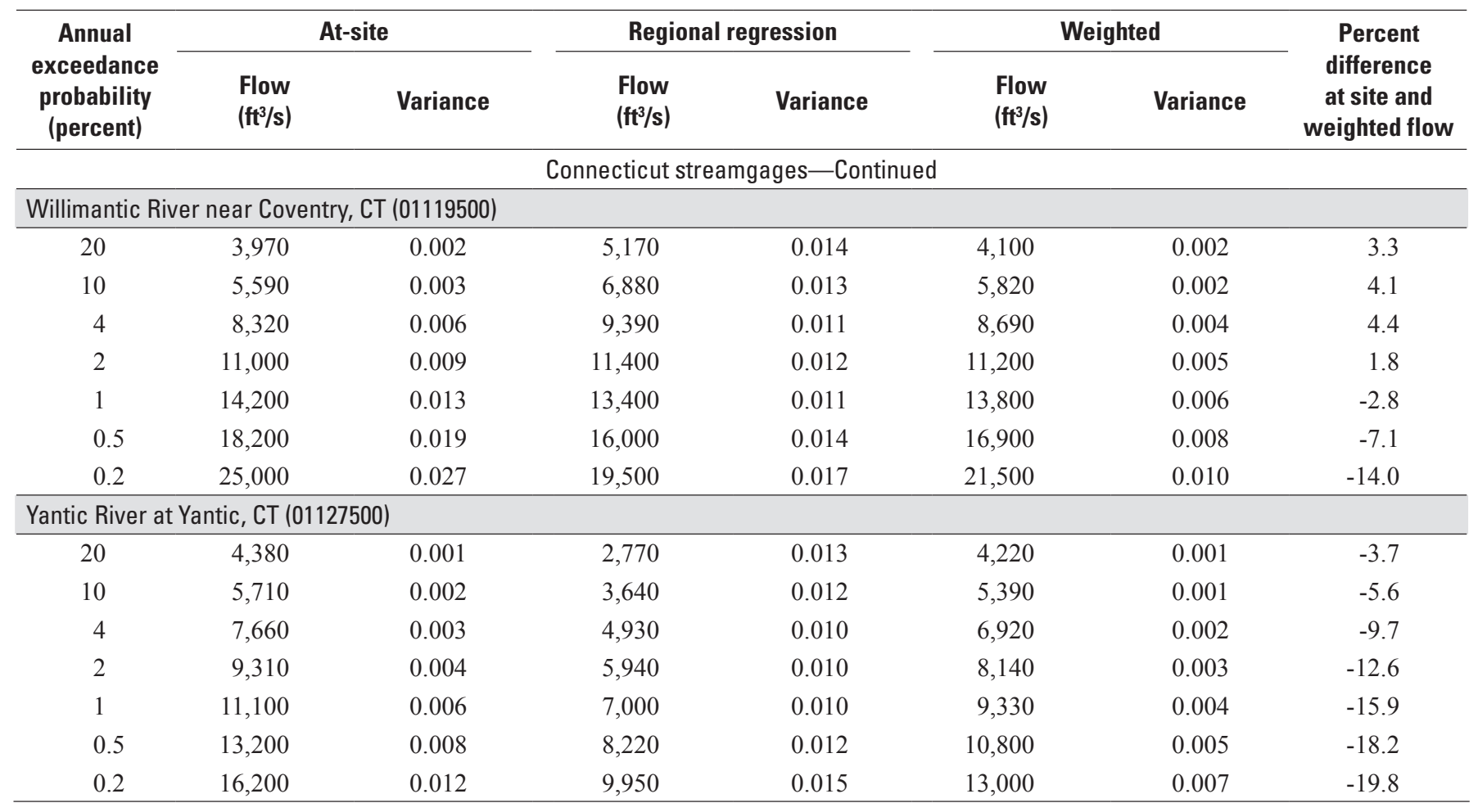




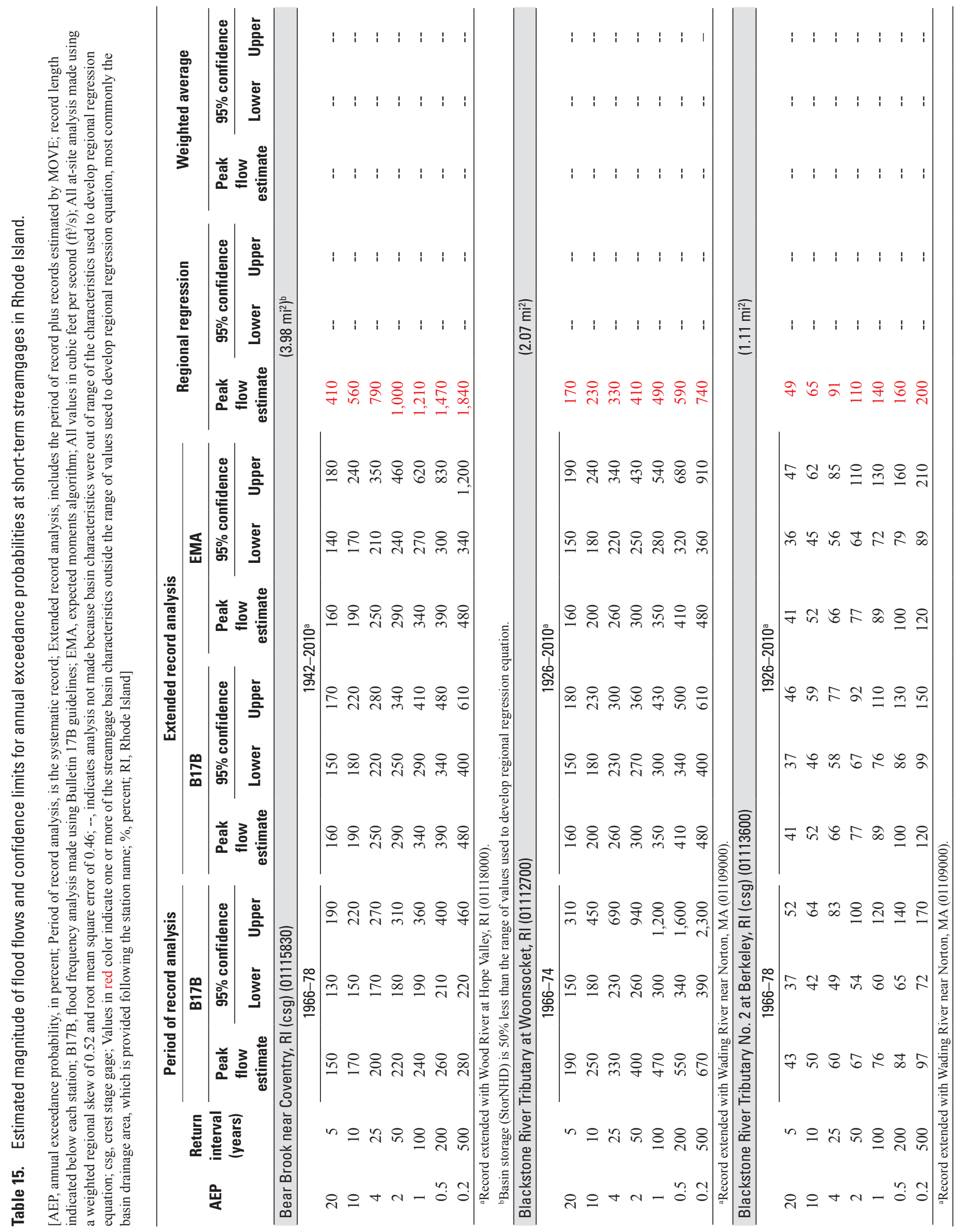




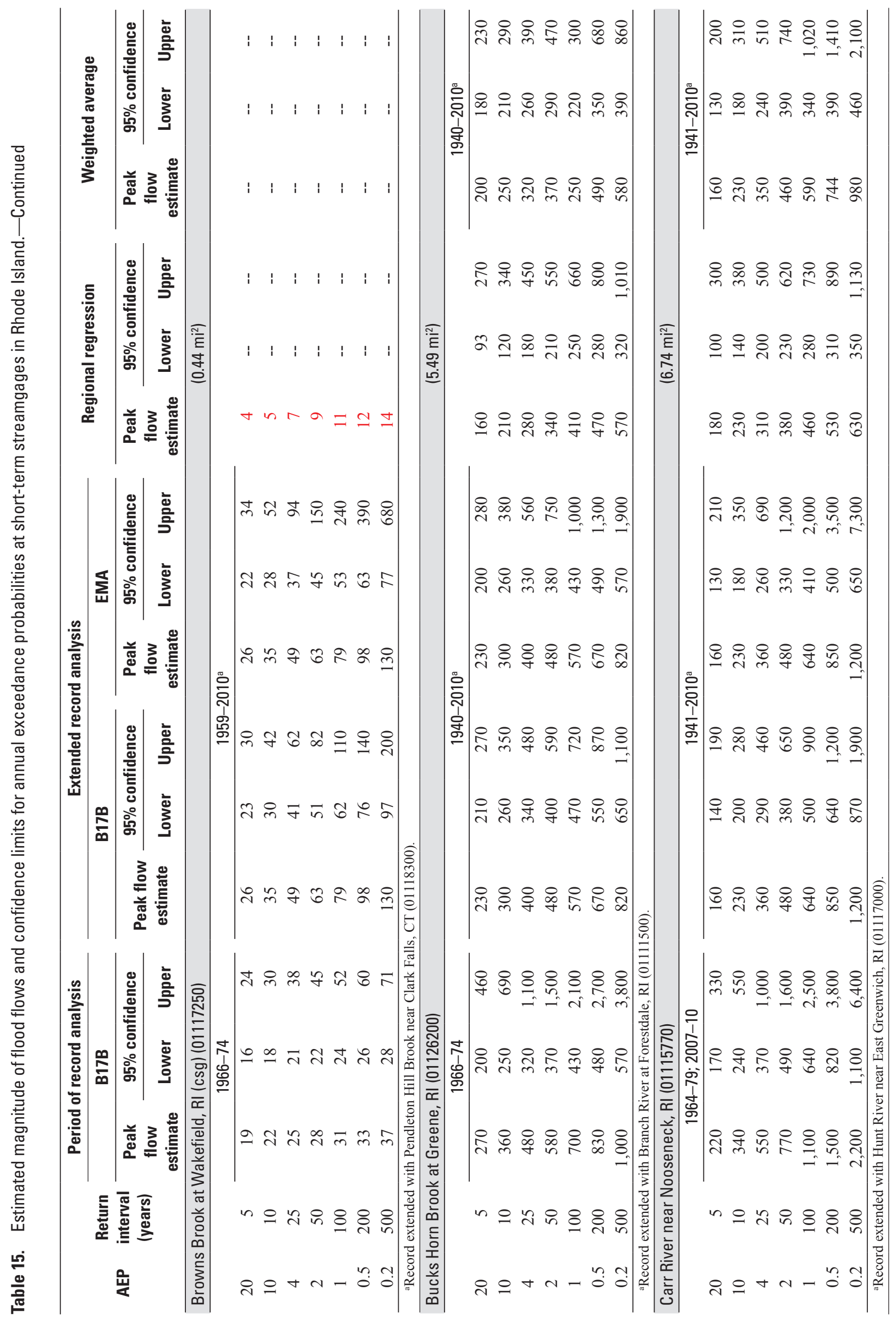




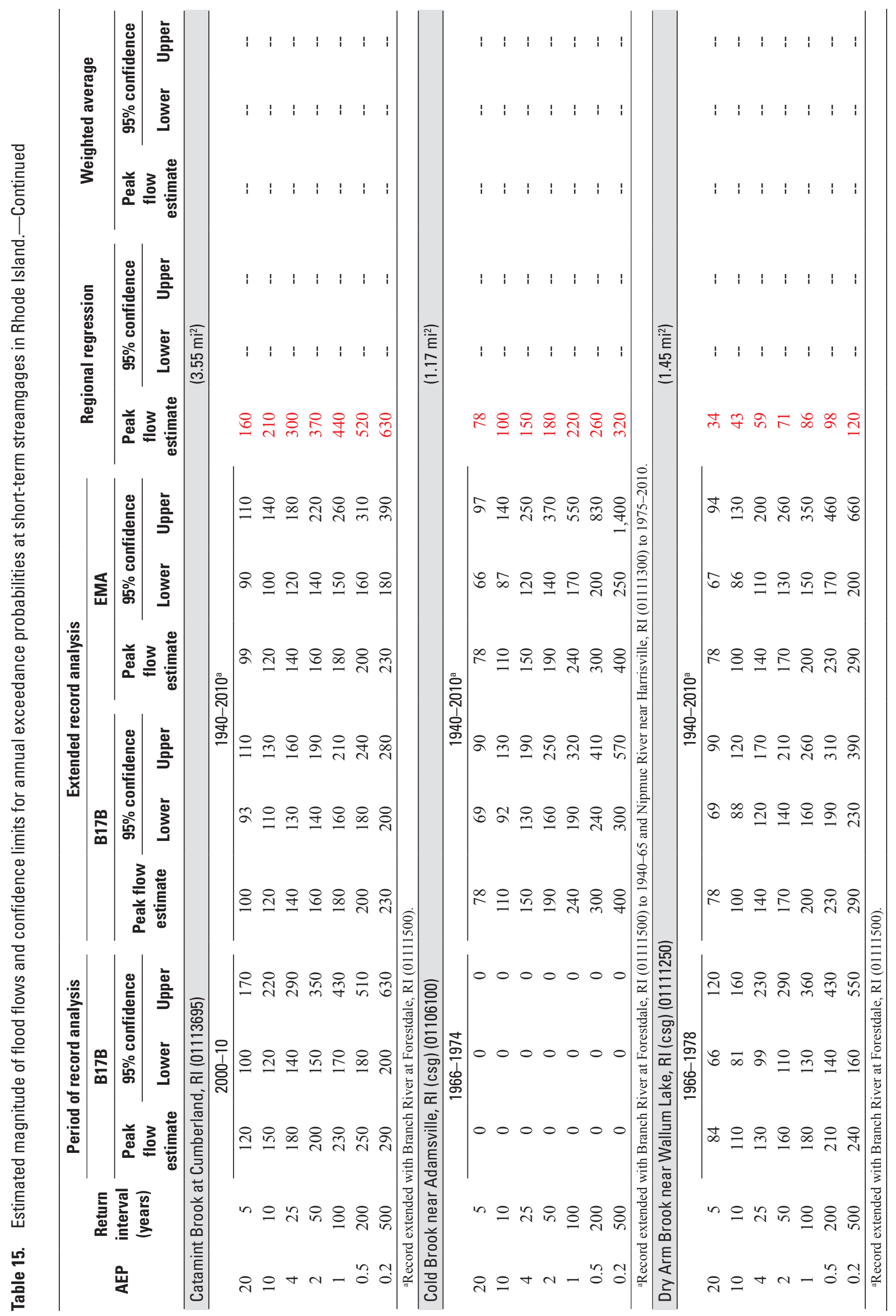




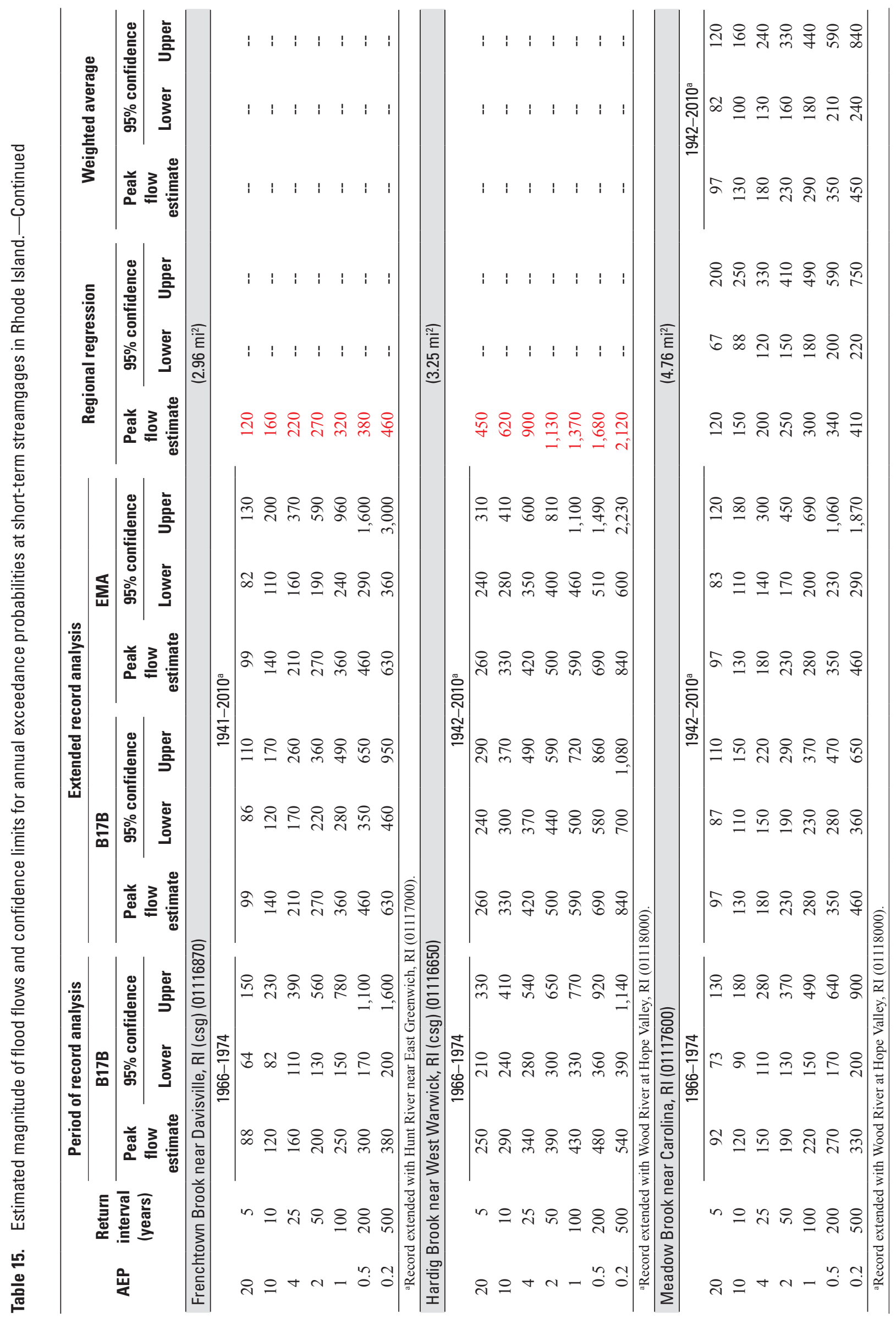




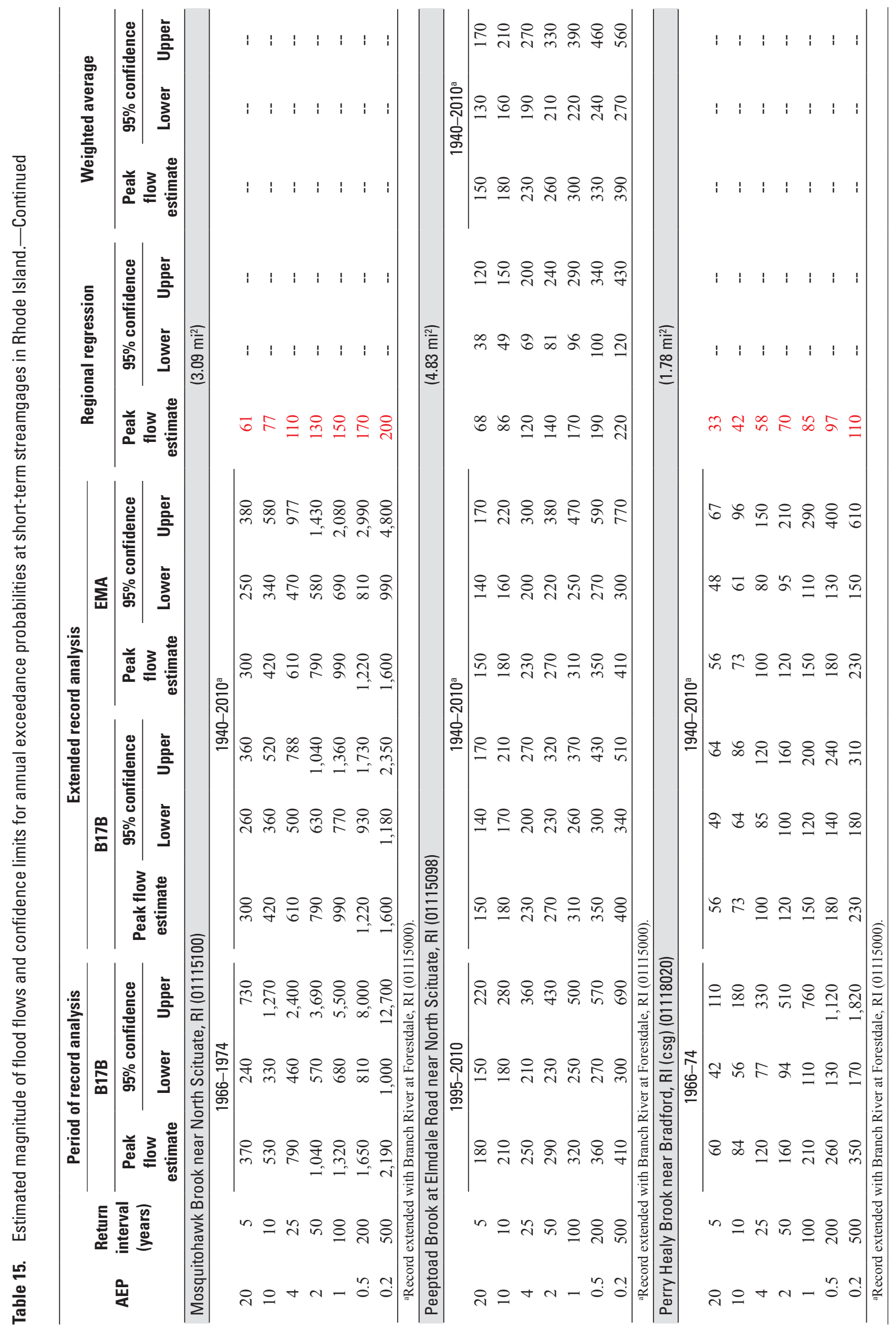


Table $15 \quad 75$

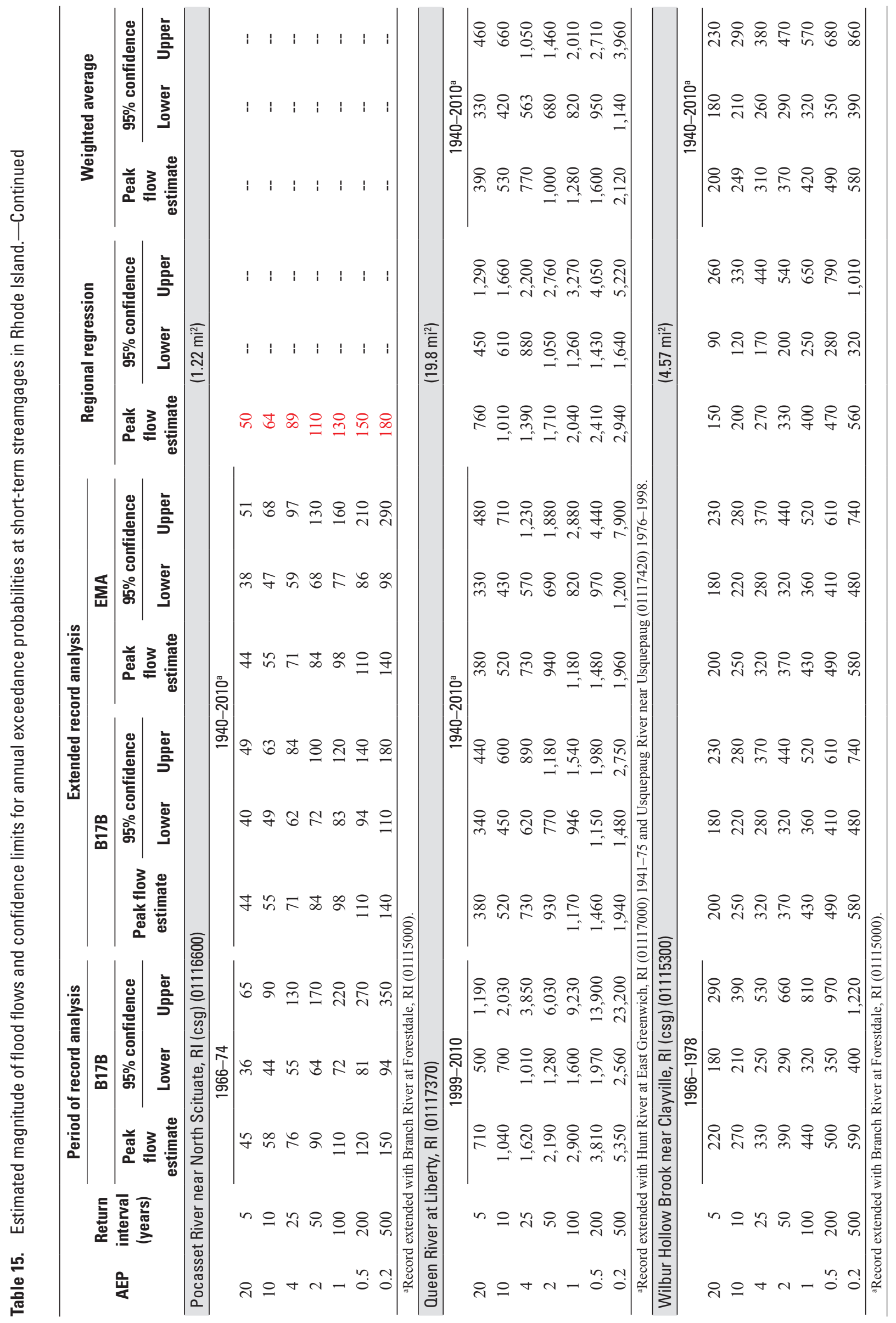




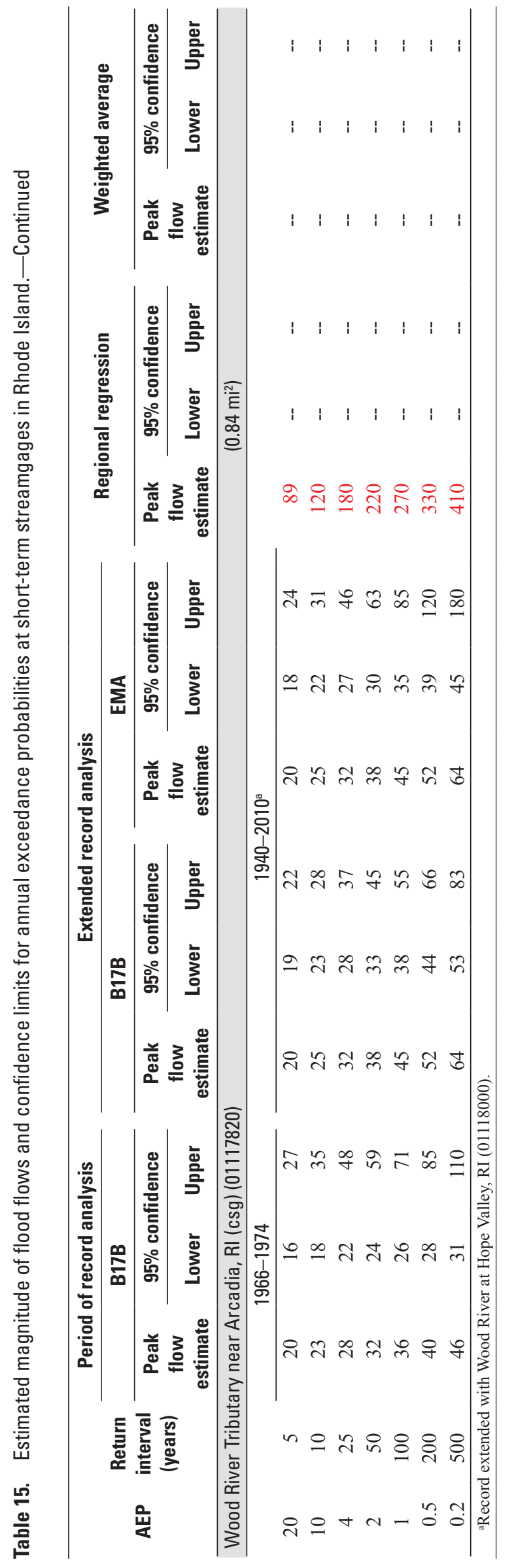


Appendixes 1-3 


\section{Appendix 1. Basin Characteristics Considered for Use in the Regional Regression Analysis}

Table 1-1. Basin characteristics tested for use as explanatory variables in regionalized regression equations for estimated flood flows at ungaged sites.

[ft, foot; $\mathrm{ft} / \mathrm{mi}$, feet per mile; mi, mile; $\mathrm{mi} / \mathrm{mi}$, miles per mile; $\mathrm{mi} / \mathrm{mi}^{2}$, miles per square mile; $\mathrm{mi}^{2}$, square mile; ${ }^{\circ} \mathrm{F}$, degrees Fahrenheit]

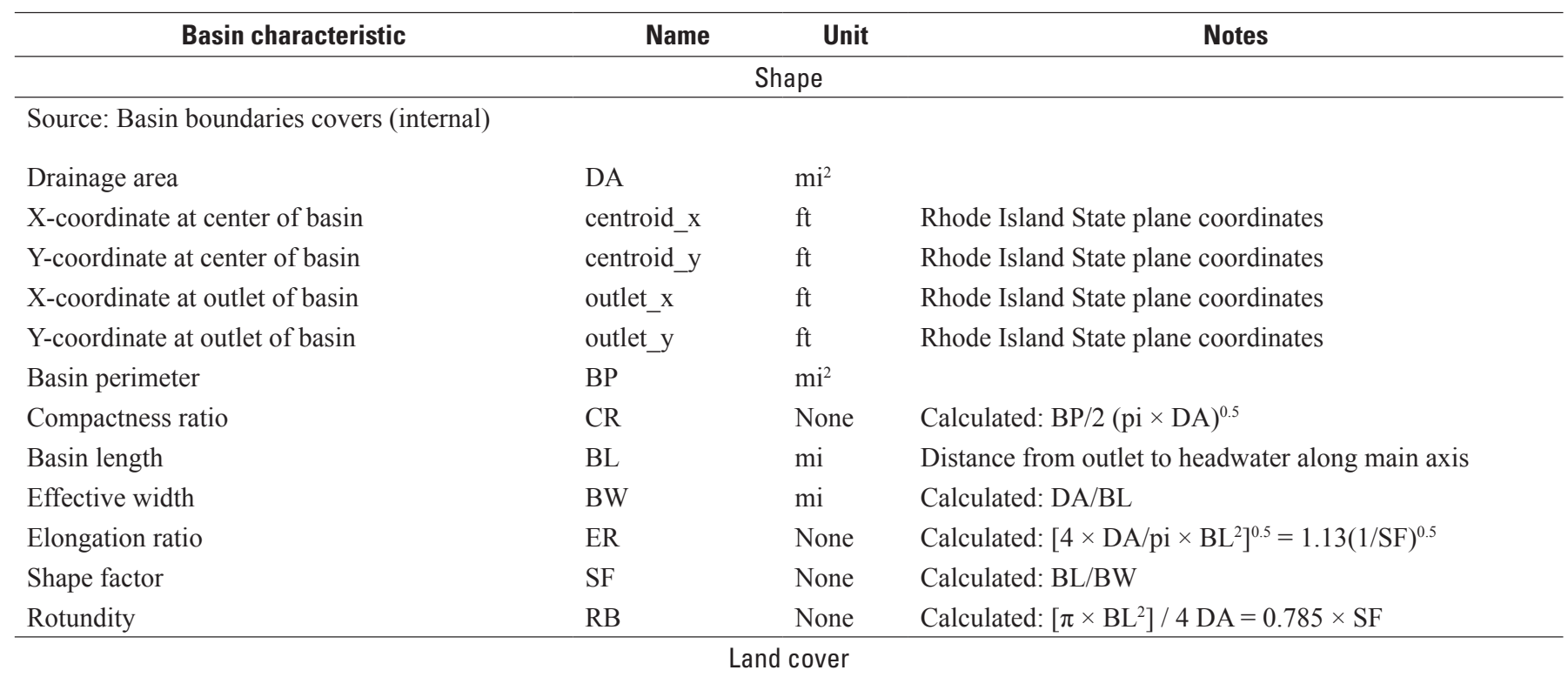

Source: National Land Cover Dataset (NLCD) 2006

http://www.epa.gov/mrlc/nlcd-2006.html

Area of open water

Area of open urban

Area of low density development

Area of moderate density development

Area of high density development

Area of moderate to high density development

Total urban area

Area of deciduous forests

Area of coniferous forests

Area of mixed forests

Total forest area

Total forest and low density development area

Area of barren land

Area of shrub land

Total open area

Area of grassland

Area of pasture

Area of cropland

Total agriculture area

Area of forested wetlands

Area of nonforest wetlands

Total wetland area

Storage area of lakes, ponds, and wetlands

$\begin{array}{lll}\text { Water } & \text { Percent } & \\ \text { OpenUrb } & \text { Percent } & \\ \text { LowDen } & \text { Percent } & \\ \text { ModDen } & \text { Percent } & \\ \text { HiDen } & \text { Percent } & \\ \text { ModHiUrb } & \text { Percent } & \text { Calculated: ModDen }+ \text { HiDen } \\ \text { AllUrban } & \text { Percent } & \text { Calculated: LowDen }+ \text { MpdDen }+ \text { HiDen } \\ \text { DecFor } & \text { Percent } & \\ \text { ConFor } & \text { Percent } & \\ \text { MixFor } & \text { Percent } & \\ \text { Forest } & \text { Percent } & \text { Calculated: DecFor }+ \text { ConFor }+ \text { MixFor } \\ \text { Forest2 } & \text { Percent } & \text { Calculated: Forest }+ \text { ForWet }+ \text { LowDen } \\ \text { Barren } & \text { Percent } & \\ \text { Shrub } & \text { Percent } & \\ \text { Open } & \text { Percent } & \text { Calculated: Barren }+ \text { Srub } \\ \text { Grass } & \text { Percent } & \\ \text { Pature } & \text { Percent } & \\ \text { Crop } & \text { Percent } & \\ \text { Agr } & \text { Percent } & \text { Calculated: Grass }+ \text { Pasture }+ \text { Crop } \\ \text { ForWet } & \text { Percent } & \\ \text { Wetland } & \text { Percent } & \\ \text { AllWet } & \text { Percent } & \text { Calculated: ForWet }+ \text { Wetland } \\ \text { StorNLCD } & \text { Percent } & \text { Calculated: Water }+ \text { AllWet } \\ & & \\ & & \end{array}$


Table 1-1. Basin characteristics tested for use as explanatory variables in regionalized regression equations for estimated flood flows at ungaged sites.-Continued

[ft, foot; ft/mi, feet per mile; mi, mile; mi/mi, miles per mile; mi $/ \mathrm{mi}^{2}$, miles per square mile; $\mathrm{mi}^{2}$, square mile; ${ }^{\circ} \mathrm{F}$, degrees Fahrenheit]

\begin{tabular}{|c|c|c|c|}
\hline Basin characteristic & Name & Unit & Notes \\
\hline \multicolumn{4}{|c|}{ Land cover-Continued } \\
\hline \multicolumn{4}{|c|}{$\begin{array}{l}\text { Source: National Land Cover Dataset (NLCD) } 2001 \text { impervous surface layer } \\
\text { http://www.csc.noaa.gov/digitalcoast/data/nlcd-impervious/index.html }\end{array}$} \\
\hline Area of impervious land & IMPERV & Percent & NLCD 2001 Impervious Surface \\
\hline \multicolumn{4}{|c|}{$\begin{array}{l}\text { Source: National Hydrography Dataset (NHD) 1:24,000 } \\
\text { http://nhd.usgs.gov/ }\end{array}$} \\
\hline Storage area of lakes, ponds, and wetlands & StorNHD & Percent & Calculated from 1:24,000 NHD \\
\hline \multicolumn{4}{|c|}{ Terrain } \\
\hline
\end{tabular}

Source: National Elevation Dataset (NED) 10-meter resolution

http://seamless.usgs.gov/ned13.php

\begin{tabular}{lll} 
Mean basin slope & MBslp & Percent \\
Mean basin elevation & ELEV & $\mathrm{ft}$ \\
Maximum basin elevation & ELEVmax & $\mathrm{ft}$ \\
Minimum basin elevation & ELEVmin & $\mathrm{ft}$ \\
Basin relief & RELIEF & $\mathrm{ft}$ \\
Basin outlet elevation & OUTLETELEV & $\mathrm{ft}$ \\
\hline & \multicolumn{2}{c}{ Infiltration }
\end{tabular}

Source: State GIS portals

http://www.mass.gov/mgis/sg24k.htm

http://www.edc.uri.edu/rigis/data/data.aspx?ISO=geoscientificInformation

http://www.ct.gov/dep/cwp/view.asp?a=2698\&q=322898

$\begin{array}{lll}\text { Area of sand and gravel deposits } & \text { SG } & \text { Percent } \\ \text { Area of till deposits } & \text { Till } & \text { Percent }\end{array}$

Source: Natural Resource Conservation Service (NRCS) SSURGO data

$\mathrm{http}: / /$ soildatamart.nrcs.usda.gov/Default.aspx

\begin{tabular}{lll} 
Area of hydrologic soils group A & SoilA & Percent \\
Area of hydrologic soils group B & SoilB & Percent \\
Area of hydrologic soils group C & SoilC & Percent \\
Area of hydrologic soils group D & SoilD & Percent \\
\hline & & Climate
\end{tabular}

Source: DAYMET - daily surface weather data and climatological summaries http://www.daymet.org/default.jsp

\begin{tabular}{|c|c|c|c|}
\hline Mean annual total precipitation & PRECIP & \multicolumn{2}{|l|}{ Inches } \\
\hline Mean maximum daily temperature & MTempF & \multicolumn{2}{|l|}{${ }^{\circ} \mathrm{F}$} \\
\hline \multicolumn{4}{|c|}{ Stream network } \\
\hline \multicolumn{4}{|c|}{$\begin{array}{l}\text { Source: National Hydrography Dataset (NHD) 1:24,000 } \\
\text { http://nhd.usgs.gov/ }\end{array}$} \\
\hline Total length of streams & STRMTOT & $\mathrm{mi}^{2}$ & \\
\hline Main channel slope & MCslp & $\mathrm{ft} / \mathrm{mi}$ & Calculated: 10 and 85 percent of main channel distance. \\
\hline Main channel sinuosity & SINOUS & $\mathrm{mi} / \mathrm{mi}$ & Calculated: MCL/BL \\
\hline Stream density & STRDEN & $\mathrm{mi} / \mathrm{mi}^{2}$ & Calculated: STRMTOT/DA \\
\hline
\end{tabular}




\section{Appendix 2. Measurement of Regression Error}

The accuracy of a regression depends on the model error and the sampling error. Model error measures the ability of the explanatory variables to estimate the flood flows calculated from the streamgage records. The model error depends on the number and predictive power of the explanatory variables in a regression equation. Sampling error measures the ability of a finite number of streamgages with a finite record to describe the true characteristics of flood flows. The sampling error depends on the number and record length of streamgages used in the analysis, which decreases as the number of streamgages and record lengths increase.

A measure of the uncertainty in a regression equation estimate for a site, $i$, is the variance of prediction, $V_{p, i}$. The $V_{p, i}$ is the sum of the model error variance and sampling error variance and is computed using the following equation (Eng and others, 2009):

$$
V_{p, i}=\gamma^{2}+M S E_{s, i}
$$

where

$$
\begin{array}{cl}
\gamma^{2} & \text { model error variance, and } \\
M S E_{s, i} & \text { sampling mean square error for site } i .
\end{array}
$$

Assuming that the explanatory variables for the streamgages in a regression analysis are representative of all streamgages in the region, the average accuracy of prediction for a regression equation is determined by computing the average variance of prediction, $A V P$, for $n$ number of streamgages:

$$
A V P=\gamma^{2}+\frac{1}{n} M S E_{s, i}
$$

A more traditional measure of the accuracy is the standard error of prediction, $S$, which is simply the square root of the variance of prediction. The average standard error of prediction for a regression equation can be computed in percent error using $A V P$, in $\log$ units, and the following transformation:

$$
S_{p, a v e}=100\left[10^{2.3026(A V P)}-1\right]^{0.5}
$$

where

$S_{p, a v e} \quad$ is the average standard error of prediction, in percent. 


\section{Appendix 3. Link to Spreadsheet RI_Flood-Flow-Equations.xls}

[Click on worksheet title below to link to spreadsheet]

Regional-FF0 Computes annual-exceedance probability (AEP) flood flows and 95-percent confidence interval from regional regression equations developed for ungaged sites in Rhode Island.

US-DS Flow Equations for improving estimates of flood flows, within certain limits, at an ungaged site on a stream above or below a gaged location in Rhode Island. 
Prepared by the Pembroke Publishing Service Center.

For more information concerning this report, contact:

Director

U.S. Geological Survey

Massachusetts-Rhode Island Water Science Center

10 Bearfoot Road

Northborough, MA 01532

dc_ma@usgs.gov

or visit our Web site at:

http://ma.water.usgs.gov 


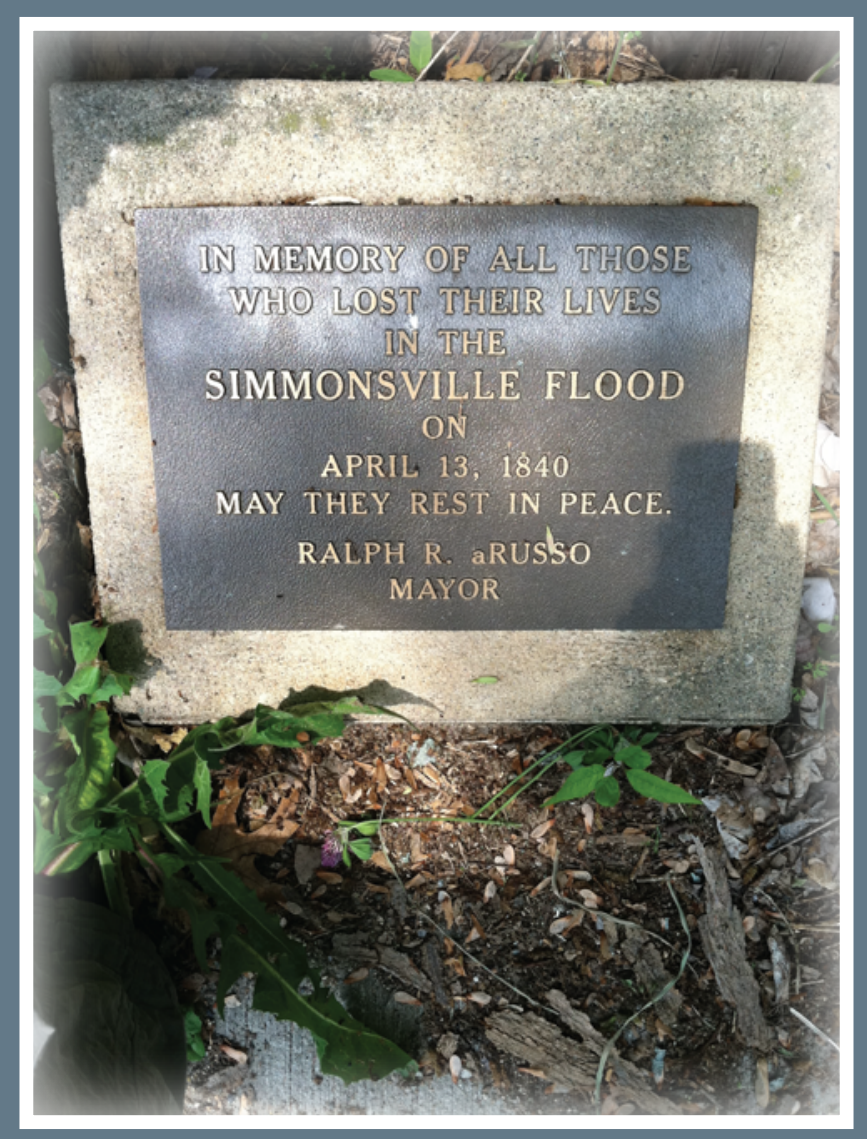

8 Printed on recycled paper

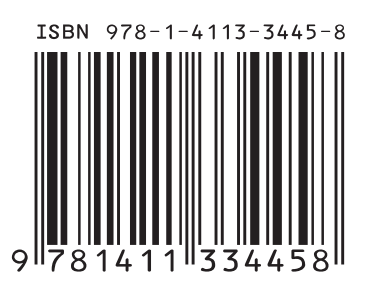


